INTERNATIONAL MONETARY FUND
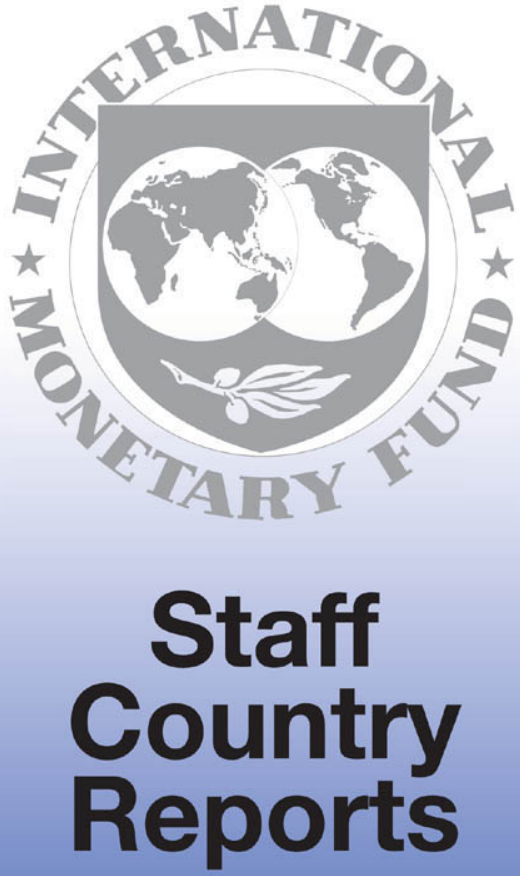


\section{Kingdom of Lesotho: Staff Report for the 2012 Article IV Consultation and Second and Third Reviews Under the Three-Year Arrangement Under the Extended Credit Facility and a Request for Augmentation of Access-Staff Report; Staff Supplement; Public Information Notice and Press Release on the Executive Board Discussion; and Statement by the Executive Director for the Kingdom of Lesotho.}

Under Article IV of the IMF's Articles of Agreement, the IMF holds bilateral discussions with members, usually every year. In the context of a combined discussion of the 2012 Article IV consultation with the Kingdom of Lesotho, the following documents have been released and are included in this package:

- $\quad$ The staff report for the combined 2012 Article IV consultation and Second and Third Reviews Under the Three-Year Arrangement Under the Extended Credit Facility and a Request for Augmentation of Access, prepared by a staff team of the IMF, following discussions that ended on February 23, 2012, with the officials of Lesotho on economic developments and policies. Based on information available at the time of these discussions, the staff report was completed on March 23, 2012. The views expressed in the staff report are those of the staff team and do not necessarily reflect the views of the Executive Board of the IMF.

- A supplement on the Joint World Bank/IMF Debt Sustainability Analysis

- A Public Information Notice (PIN) and Press Release, summarizing the views of the Executive Board as expressed during its April 9, 2012, discussion of the staff report on issues related to the Article IV consultation and the IMF arrangement, respectively.

- $\quad$ A statement by the Executive Director for the Kingdom of Lesotho.

The documents listed below have been or will be separately released.

Letter of Intent sent to the IMF by the authorities of Lesotho*

Memorandum of Economic and Financial Policies by the authorities of Lesotho*

Technical Memorandum of Understanding*

Poverty Reduction Strategy Paper

*Also included in Staff Report

The policy of publication of staff reports and other documents allows for the deletion of market-sensitive information.

Copies of this report are available to the public from

International Monetary Fund $\bullet$ Publication Services

$70019^{\text {th }}$ Street, N.W. $\bullet$ Washington, D.C. 20431

Telephone: (202) 623-7430 • Telefax: (202) 623-7201

E-mail: publications@imf.org Internet: http://www.imf.org

\section{International Monetary Fund Washington, D.C.}


This page intentionally left blank 
INTERNATIONAL MONETARY FUND

KINGDOM OF LESOTHO

\title{
Staff Report for the 2012 Article IV Consultation and Second and Third Reviews Under the Three-Year Arrangement Under the Extended Credit Facility and a Request for Augmentation of Access
}

\author{
Prepared by the African Department in Consultation with Other Departments
}

Approved by Anne-Marie Gulde-Wolf and Taline Koranchelian

March 23, 2012

- Extended Credit Facility arrangement: The first review under the Extended Credit Facility (ECF) arrangement was concluded on April 4, 2011, on a lapse-of-time basis. The Executive Board approved a three-year ECF arrangement for SDR 41.88 million (120 percent of quota) in June 2010, against the backdrop of a sharp fall in revenues from the Southern African Customs Union (SACU). The authorities are requesting an augmentation of access in an amount equivalent to SDR 8.73 million (25 percent of quota) to cushion the impact of the 2010-11 flood damage and high international commodity prices.

- Review: The ECF-supported program is on track. All quantitative performance criteria for end-March and end-September 2011 were met. Structural reforms have been progressing, albeit with some delay. The second review—originally scheduled for completion in August 2011—was postponed pending the finalization of the National Strategic Development Plan (NSDP). With the recent submission of the NSDP to the Boards of the IMF and the World Bank as a PRS document, staff recommends completion of the second and third reviews under the ECF arrangement. Staff also supports the authorities' request for augmentation of access under the arrangement, given continued financing needs for flood-related rehabilitation programs.

- Discussions: The mission visited Maseru June 15-28, December 2-15, 2011, and February 17-23, 2012 and met with Finance and Development Planning Minister Thahane; Central Bank of Lesotho Governor Matlanyane; other senior government officials; and representatives of the donor community, the private sector, and labor unions. The staff team comprised J. Honda (head), M. Morgan, S. Thomas, D. Benicio, A. Oshima, F. Gwenhamo (all AFR), M. Tharkur and C. Saborowski (both SPR). Press releases were issued at the end of the June and December 2011 missions.

- Exchange regime: Lesotho is a member of the Common Monetary Area (CMA) and the Lesotho loti is pegged at par to the South African Rand, which is also legal tender in the country. Lesotho has accepted the obligations of Article VIII, Sections 2, 3, and 4, of the Articles of Agreement and maintains an exchange system free of restrictions on the making of payments and transfers for current international transactions.

- Publication: The authorities have consented to publication of the staff report and the program documents. 


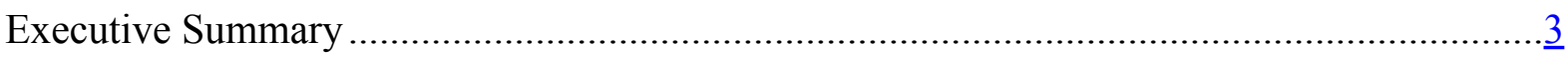

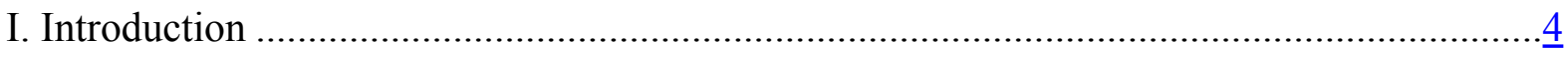

II. Recent Economic Developments and Program Performance ............................................ 4

III. Article IV Consultation Discussion ..................................................................... $\underline{8}$

A. Policies to Ensure Macroeconomic Stability ........................................................ 8

B. Policies to Achieve Sustained Growth in the Medium-Term ................................10

C. Medium-term Outlook.......................................................................................

IV. Program Monitoring, Poverty Reduction Strategy, and Safeguards Assessment............... $\underline{18}$

A. Case for Augmentation ............................................................................. $\frac{18}{20}$

B. Program Monitoring .............................................................................. $\frac{20}{20}$

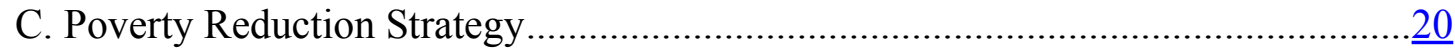

D. Safeguards Assessment .....................................................................

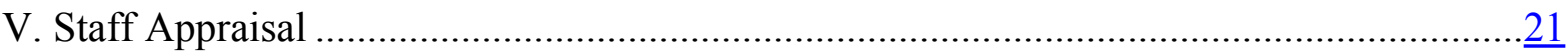

Tables

1. Selected Economic Indicators, 2009/10-2016/17 ..................................................... 23

2. Fiscal Operations of the Central Government, 2009/10-2016/17 (Maloti millions)...........24

3. Fiscal Operations of the Central Government, 2009/10-2016/17 (Percent of GDP) ..........25

4. Monetary Accounts, 2009-13 ............................................................................... $\frac{26}{27}$

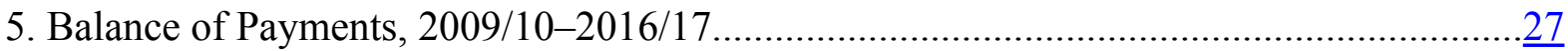

6. Commercial Bank Performance Ratios, 2005-11 ….....................................................

7. Indicators of Capacity to Repay to IMF ..........................................................................29

8. Schedule of ECF Disbursements and Reviews, 2011-13 ............................................. $\underline{30}$

9. Millennium Development Goals ..................................................................................

Boxes

1. Diamond Sector ................................................................................................. 7

2. Impacts of Recent Floods and High International Commodity Prices on International

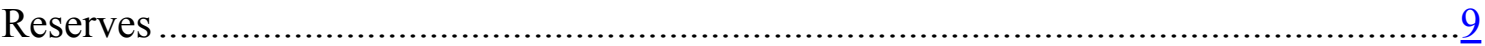

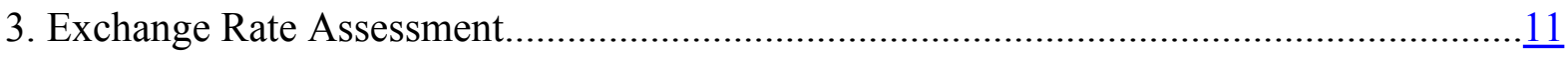

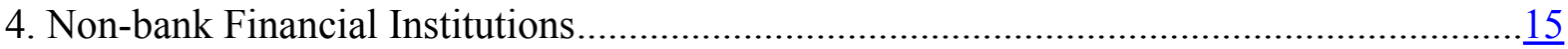

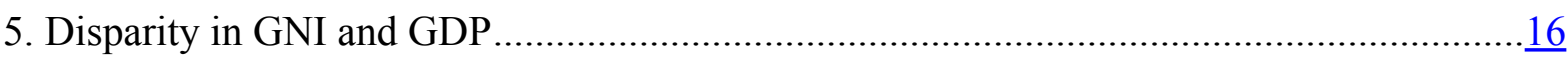

Appendix

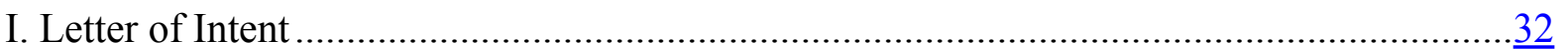

Attachments

1. Memorandum of Economic and Financial Policies .................................................... $\frac{34}{44}$

2. Technical Memorandum of Understanding ............................................................. 44 


\section{EXECUTIVE SUMMARY}

Despite the unfavorable external environment, Lesotho has maintained robust growth, mainly driven by an expanding mining sector. Real GDP growth for 2010/11 is estimated at 53/4 percent; inflation rose gradually in 2011, driven by international commodity prices. Despite the sharp drop in Southern African Customs Union (SACU) revenues, fiscal performance in 2010/11 was much better than programmed, reflecting higher domestic revenue collections and cuts in recurrent spending. The non-SACU balance improved sharply from a deficit of 37 percent of GDP in 2009/10 to a deficit of 21 percent of GDP in 2010/11. This strong fiscal consolidation effort helped to limit the external current account deficit to 15 percent of GDP in 2010/11.

Macroeconomic conditions remain challenging for 2011/12, because of the impact of floods and high international commodity prices. The floods through early 2011 caused widespread damage and loss of lives. Agriculture was hard hit, necessitating emergency food imports. Infrastructure damage has also been significant. The total cost for post-flood recovery and reconstruction is estimated at $3 \frac{1}{2}$ percent of GDP. Because of these pressures, Lesotho continues to face pressure on international reserves. With further fiscal adjustment efforts, the fiscal balance is now expected to exceed program targets for 2011/12. Against this background, the authorities are requesting augmentation of access under the Extended Credit Facility (ECF) arrangement to help address the balance of payment needs resulting from these shocks.

The ECF-supported program is on track. All quantitative performance criteria for endMarch 2011 and end-September 2011 were met. Three structural benchmarks for end-March and end-June have been implemented as programmed, while two benchmarks were implemented with delays. Two remaining benchmarks - including the completion of an audit of domestic arrears - are expected to be completed by end-March, and one has been postponed to end-September 2012.

Policy discussions focused on policies to ensure macroeconomic stability and achieve sustained growth in the medium-term. Given Lesotho's vulnerability to exogenous shocks, sound fiscal and macro policies would ensure an adequate level of international reserves to maintain the exchange rate peg. The authorities are committed to maintaining fiscal adjustment efforts to restore fiscal and external sustainability, targeting an international reserve cushion of five months of imports over the medium-term. The economic program includes appropriate measures to improve revenue collection and expenditure rationalization, while safeguarding priority social spending. With further adjustment efforts, as well as with some recovery in SACU revenues, the overall fiscal position is projected to record a balance in 2012/13. To achieve sustained growth and increase employment, structural reforms to promote private sector development is called for, as recognized in the National Strategic Development Plan (NSDP).

Staff recommends completion of the second and third reviews under the three-year ECF arrangement, and the augmentation of access to resources under the ECF arrangement by SDR 8.73 million (equivalent to 25 percent of quota) as this would help Lesotho achieve an adequate level of reserves to reduce balance of payments risks. Risks to the program can be mitigated by sound policies and reforms, in coordination with Lesotho's development partners. 


\section{INTRODUCTION}

1. In recent years, Lesotho was faced with a significant fall in revenues from the Southern African Customs Union (SACU), necessitating sizable macroeconomic adjustments. During the 2009 Article IV consultation discussion, Executive Directors observed significant challenges going forward because the projected decline in SACU revenues was expected to result in large fiscal and external deficits. In this light, actions were required on several fronts; containing the growth of non-priority expenditure (while safeguarding spending on vulnerable groups), enhancing the efficiency of public expenditure, and strengthening the mobilization of non-SACU revenues. To promote broad-based growth, they also stressed the need for efforts to reduce the cost of doing business and improve the investment climate, in line with the authorities' strategy to advance economic diversification and facilitate private sector development.

\section{The authorities have been implementing reforms in line with the Fund advice.} Adjustment policies under the Extended Credit Facility (ECF) have been implemented since June 2010. The impacts of the SACU revenue fall on fiscal and external balances have been mitigated, in part through significant fiscal tightening.

3. Nonetheless, new challenges have emerged. The floods through early 2011 caused widespread damage and loss of lives across the country. The agricultural sector has been particularly affected, with heavy losses of crops and livestock, thus giving rise to the need for emergency food imports. Infrastructure damage (to roads, water supply and sanitation) has also been significant. In addition, international commodity prices have stayed high, while uncertainties surrounding global economic outlook are persisting. In this context, the emphasis in the remainder of Lesotho's ECF-supported adjustment program is to step up fiscal adjustment effort in the medium-term (including reforms in public financial management and tax administration), enhance growth through improving the business climate and promote financial intermediation under proper supervisory oversight. The authorities are seeking external support, including augmentation of access under the ECF arrangement, to address the increased balance of payments needs.

\section{Recent Economic Developments and Program Performance}

\section{Despite the flood-related damage, Lesotho} has maintained robust growth, driven mainly by an expanding mining sector. Agriculture-which was already facing rising costs of inputs such as fertilizer and fuel- had to bear heavy losses of crops and livestock because of the floods. The infrastructure damage also affected the transportation and commercial sectors. Mining sector, however, grew rapidly in response to strong international demand, high prices, and resumption of operations of two mines (Box 1).

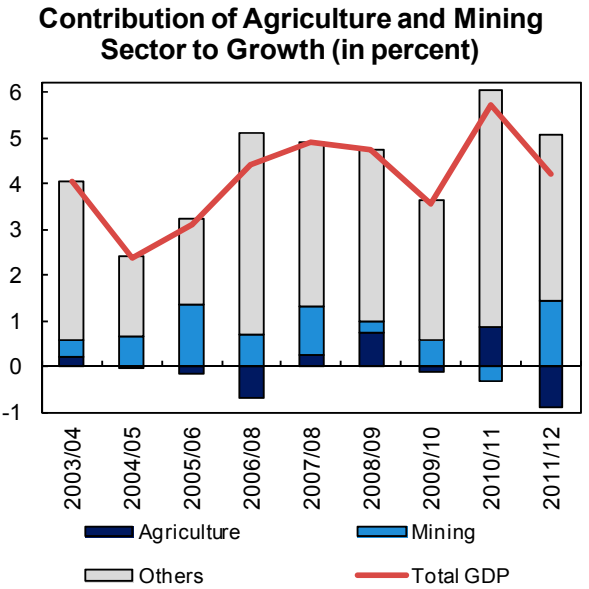

Sources: Lesotho authorities and IMF staff estimates. 
5. Inflation rose in 2011. After moderating to 3.1 percent by December 2010 - benefiting from the strong South African rand to which the local currency is pegged - inflation steadily increased in 2011 and headline inflation reached 7 percent in December, reflecting high international commodity prices and agricultural supply shortages following months of floods.

\section{The authorities made significant progress in} fiscal adjustment in 2010/11 to address the sharp

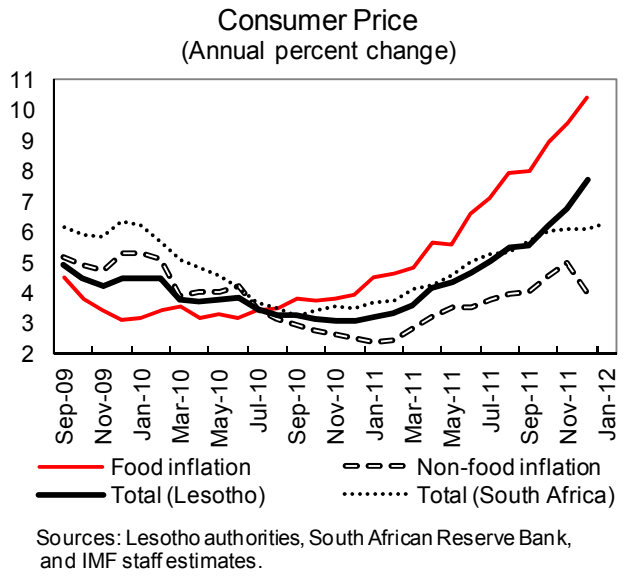
drop in SACU revenues. Fiscal performance was better than programmed, as a result of higher domestic revenue collections (including transfer of the central bank's retained earnings) and cuts in recurrent spending. The core SACU fiscal deficit declined from 20 percent of GDP in 2009/10 to 5 $\frac{1}{2}$ percent of GDP in 2010/11 (see text table). ${ }^{1}$ This improvement contained the external current account deficit to 15 percent of GDP in 2010/11.

\section{In 2011/12, higher government spending - albeit below program expectation-is} projected to place additional pressures on fiscal and external balances. The core-SACU fiscal deficit is projected to increase to $73 / 4$ percent of GDP, mainly because of (i) one-off flood-related outlays (1.1 percent of GDP), (ii) the cost of local and general elections (1.4 percent of GDP), and (iii) lower central bank profit transfer. The additional outlays, together with high commodity prices, are projected to worsen the current account deficit to $16 \frac{1}{2}$ percent of GDP. International reserves fell to the equivalent of about four months of import coverage by end-2011.

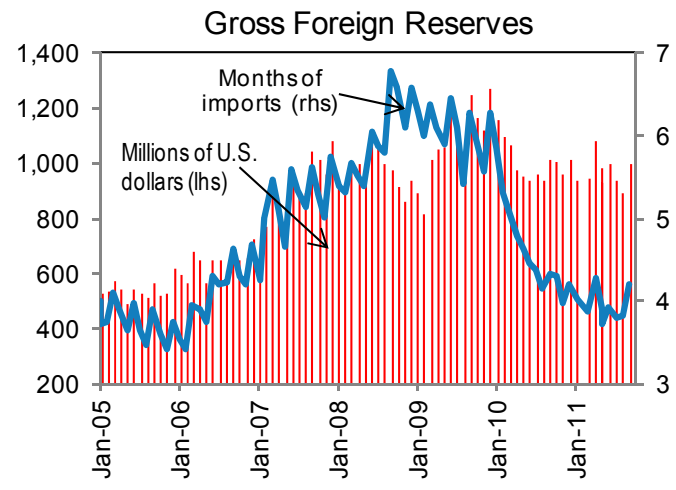

Sources: Central Bank of Lesotho and IMF staff estimates.

\footnotetext{
${ }^{1}$ The core SACU fiscal balance - defined as the fiscal balance excluding the volatile component of SACU revenues and foreign-financed project loans - is the key policy anchor for fiscal consolidation efforts. The volatile component of SACU revenues is defined as the total SACU revenues minus the core component equivalent to 15 percent of GDP. This is the lowest annual SACU receipt in the last two decades.
} 


\begin{tabular}{|c|c|c|c|c|c|c|c|c|c|c|}
\hline & \multicolumn{10}{|c|}{ Fiscal Performance 2009/10-2016/17 ${ }^{12}$} \\
\hline & \multicolumn{2}{|c|}{$\underline{2009 / 102010 / 11}$} & \multicolumn{2}{|c|}{$2011 / 12$} & \multicolumn{2}{|c|}{$2012 / 13$} & \multirow{2}{*}{$\begin{array}{c}\text { 2013/14 } \\
\text { Proj. }\end{array}$} & \multirow{2}{*}{$\begin{array}{c}\text { 2014/15 } \\
\text { Proj. }\end{array}$} & \multirow{2}{*}{$\begin{array}{r}2015 / 16 \\
\text { Proj. }\end{array}$} & \multirow{2}{*}{$\begin{array}{r}2016 / 17 \\
\text { Proj. }\end{array}$} \\
\hline & Act. & Prel. & EBS/11/44 & Proj. & EBS/11/44 & Proj. & & & & \\
\hline \multicolumn{11}{|c|}{ (in percent of GDP) } \\
\hline Revenue and Grants & 62.8 & 52.5 & 51.8 & 51.6 & 60.5 & 65.5 & 58.6 & 51.9 & 52.0 & 50.9 \\
\hline Tax Revenue & 21.4 & 21.5 & 21.9 & 21.6 & 21.7 & 21.5 & 22.3 & 21.5 & 22.4 & 23.3 \\
\hline Non-tax revenue & 5.2 & 7.6 & 5.1 & 6.3 & 5.0 & 6.0 & 5.9 & 5.8 & 5.4 & 5.3 \\
\hline SACU & 33.1 & 16.1 & 15.2 & 15.2 & 21.4 & 29.0 & 24.9 & 21.8 & 20.8 & 19.2 \\
\hline Core SACU & 15.0 & 15.0 & 15.0 & 15.0 & 15.0 & 15.0 & 15.0 & 15.0 & 15.0 & 15.0 \\
\hline Non-core SACU & 18.1 & 1.1 & 0.2 & 0.2 & 6.4 & 14.0 & 9.9 & 6.8 & 5.8 & 4.2 \\
\hline Grants & 3.0 & 7.4 & 9.6 & 8.5 & 12.4 & 9.0 & 5.4 & 2.7 & 3.4 & 3.0 \\
\hline Budget support & 0.0 & 2.3 & 0.8 & 1.1 & 0.5 & 1.5 & 1.4 & 0.5 & 0.4 & 0.4 \\
\hline Project grants & 3.0 & 5.1 & 8.8 & 7.4 & 11.9 & 7.5 & 4.0 & 2.3 & 3.0 & 2.7 \\
\hline Flood support & & & 0.0 & 0.1 & 0.0 & 0.0 & 0.0 & 0.0 & 0.0 & 1.0 \\
\hline $\begin{array}{l}\text { Total Expenditure } \\
\text { o/w Flood-related }\end{array}$ & 66.7 & 57.5 & 66.8 & 62.1 & 65.8 & 65.3 & 57.8 & 49.7 & 47.7 & 46.7 \\
\hline Recurrent & 48.0 & 39.1 & 44.5 & 40.5 & 39.5 & 40.7 & 38.7 & 36.2 & 32.5 & 31.6 \\
\hline$o / w$ Wages \& salaries & 17.1 & 16.6 & 17.5 & 17.4 & 16.3 & 15.9 & 15.2 & 13.8 & 12.8 & 12.4 \\
\hline Capital expenditure & 18.7 & 18.4 & 22.3 & 21.6 & 26.3 & 24.6 & 19.1 & 13.5 & 15.2 & 15.1 \\
\hline$o / w$ Domestically funded & 13.8 & 11.6 & 8.9 & 10.9 & 8.5 & 11.8 & 10.1 & 9.3 & 9.5 & 10.1 \\
\hline Overall Balance, incl. grants & -3.9 & -5.0 & -15.0 & -10.5 & -5.3 & 0.2 & 0.7 & 2.2 & 4.3 & 4.3 \\
\hline Overall Balance, excl. grants & -6.9 & -12.4 & -24.6 & -19.0 & -13.9 & -8.8 & -4.7 & -0.6 & 0.9 & 1.2 \\
\hline Core-SACU Fiscal balance & -20.2 & -5.4 & & -7.8 & & -8.6 & -4.2 & -2.7 & 1.0 & 2.4 \\
\hline Non-SACU Balance & -37.0 & -21.2 & -30.2 & -25.6 & -26.7 & -28.8 & -24.2 & -19.6 & -16.5 & -15.0 \\
\hline Financing & -0.4 & 2.1 & 15.0 & 10.5 & 5.3 & -0.2 & -0.7 & -2.2 & -4.3 & -4.3 \\
\hline Domestic (net) & -0.5 & 2.5 & 12.3 & 9.0 & 0.3 & -4.3 & -4.4 & -3.0 & -6.1 & -5.8 \\
\hline Foreign (net) & 0.1 & -0.4 & 2.7 & 1.5 & 5.0 & 4.1 & 3.7 & 0.8 & 1.8 & 1.5 \\
\hline Staistical Discrepancy & 4.3 & 3.0 & 0.0 & 0.0 & 0.0 & 0.0 & 0.0 & 0.0 & 0.0 & 0.0 \\
\hline
\end{tabular}

8. The ECF-supported program is on track. All quantitative performance criteria (PCs) for end-March and September 2011 were met. Net domestic financing of the government and net international reserves were well above the targets, reflecting the authorities' stepped-up adjustment efforts and postponement of some capital projects to 2012/13. The indicative target for the floor on social spending was also met. Finally, spending on key social programs, such as the school feeding program, old-age pensions, and HIV/AIDS have been preserved, with the floor increased to M732 million, equivalent to $3 \frac{1}{2}$ percent of GDP.

9. Structural reforms have progressed, albeit with some delays. Three structural benchmarks for end-March and end-June have been implemented as programmed, while the reforms covered by two other benchmarks were implemented with delays, and three structural benchmarks have been postponed. In the financial sector, the Financial Institutions Bill was submitted to parliament in March 2011 and enacted in February 2012, paving the way for further strengthening of the supervisory and regulatory framework for banks and nonbanks. In public financial management (PFM), the audit of domestic arrears was not completed, in part because of problems with the Integrated Financial Management Information System (IFMIS). Based on recommendations of IMF technical assistance in July 2011, a time-bound audit plan has been formulated to complete the audit by end-March 2012 (MEFP ๆ16). 


\section{Box 1. Lesotho: Diamond Sector}

Diamond production is becoming an important source of growth in Lesotho. The diamond sector only accounted for less than $1 / 2$ percent of GDP until early 2000s. However, in recent years, the sector has grown significantly, with the reactivation of three mines. The sector accounted for 7 percent of GDP in 2010/11. With further expansion of the existing mines and coming onstream of more mines, the diamond sector is expected to grow further, exceeding 20 percent of GDP by 2016/17. This pace of expansion of the sector is prominent, compared with neighboring diamond-producing countries. Lesotho's diamonds are of high quality and the value per carat of rough diamonds is the highest in the world. Historically, the price of diamond has been more volatile than those of diamonds produced in neighboring countries.

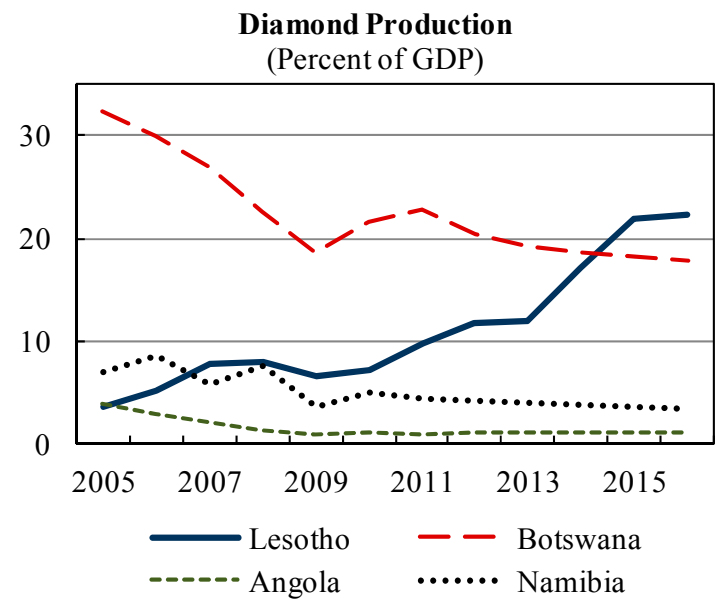

Source: Country authorities and IMF staff estimates.

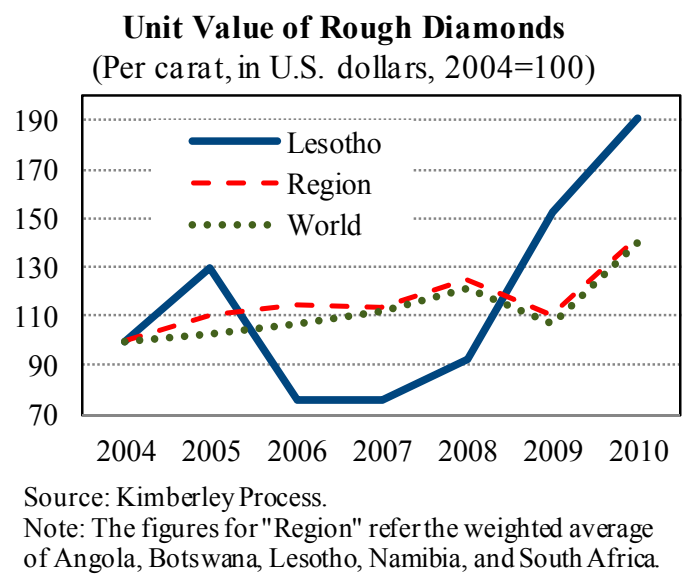

Unit Value of Rough Diamonds

Note: The figures for "Region" refer the weighted average of Angola, Bots wana, Lesotho, Namibia, and South Africa

The diamond sector has a large impact on Lesotho's economy, through various channelsexports, government revenue, and employment:

- Exports. Diamond export is expected to increase significantly from 24 percent of total exports in 2010 to 54 percent in 2016. Furthermore, a significant amount of FDI, about US\$1,100 million, is expected in the next five years. Both diamond export and foreign investment in diamond mines generate foreign earnings, although their net impact on international reserves would be limited because of associated foreign outflows (through profit transfers to foreign mining companies and imports of capital goods for mining).

- Government revenues. The diamond sector contributes to fiscal revenue through four channels: corporate tax, dividend payments on state shareholdings, royalties and land rent. In 2011/12, the government is projected to collect about 330 million maloti (about 4 percent of total revenues). With further growth of the diamond sector and diminishing depreciation cost of the new mines, corporate taxes and royalties are expected to increase; and the share of the revenues from the diamond sector would increase to about 8 percent of total revenues by 2016/17.

- Employment. Employment creation in the diamond sector has been modest because diamond mining is capital intensive in nature. The sector employs about 2,000 workers (about 0.3 percent of the total employment) and is expected to absorb another 1,000 workers by $2016 / 17$, with activation of some new plants. 


\section{Article IV Consultation Discussion}

\section{A. Policies to Ensure Macroeconomic Stability}

Restoring macroeconomic stability in the face of the sharp drop in SACU revenues is essential to preserving short-term growth. In the short-term, the key policy objectives are to maintain fiscal and external sustainability, while ensuring sufficient financing for the postflood recovery and reconstruction.

10. The floods and high commodity prices have added pressure on international reserves, with an estimated increase in Lesotho's import cost by 4 percent of GDP

(Box 2). International fuel and food prices rose since mid-2010, adding substantially to import costs (by $13 / 4$ percent of GDP). In addition, the flooding has necessitated significant external financing needs for reconstruction and emergency food imports (estimated at about US\$60 million, equivalent to $2 \frac{1}{2}$ percent of GDP).

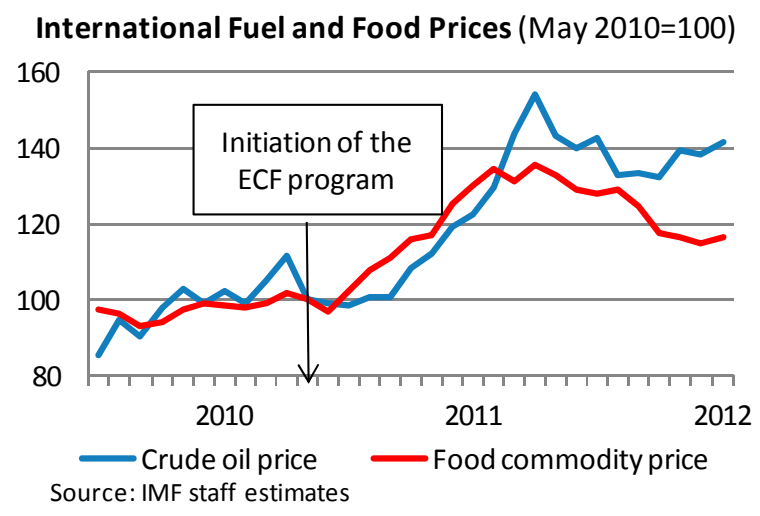

\section{The authorities have made further progress in fiscal consolidation, while} covering part of flood-related capital outlays in 2011/12. Despite such additional spending needs, the authorities are committed to containing the overall fiscal deficit at $10 \frac{1}{2}$ percent of GDP in 2011/12, lower than the level (15 percent) agreed to during the first review of the ECF-supported program. The authorities have maintained strict control over spending on goods and services. To cover the remainder of the flood-related cost, the authorities have also sought development partners' support, while drawing down on its limited reserves buffer. Following the establishment of a fund, Lesotho's development partners have so far pledged US\$2.8 million (about 3 percent of the total costs).

12. To help achieve their fiscal consolidation targets in the short and medium term, the authorities plan to enhance the efficiency of revenue administration and improve the quality of spending. Based on technical assistance from the IMF, the authorities will undertake a full restructuring of the Lesotho Revenue Authority (LRA) in 2012/13, including the operationalization of a full-service Large Tax Payer Unit by end-March 2013, which will cater to medium-to-large taxpayers. In the event that revenues turn out higher than expected in $2012 / 13$, the authorities plan to use the additional resources to rebuild their deposits at the Central Bank of Lesotho (CBL). On the expenditure side, emphasis will be on strengthening cash management, facilitating reconciliation of government accounts at the central bank and commercial banks, and prioritizing social and development spending. Attention will also be paid to stricter enforcement of the use of budgetary contingencies, to ensure their use for real unforeseen emergencies. 


\section{Box 2. Lesotho: Impacts of Recent Floods and High International Commodity Prices on International Reserves}

Lesotho experienced flood rains starting in late-December 2010, causing large import needs for reconstruction and recovery. The agricultural sector was most affected, followed by road transport and commerce, raising concerns about food security in rural areas. The Food and Agricultural Organization estimates that in some of the worst-hit districts, up to 60 percent of crops has been destroyed, and the Post-Disaster Needs Assessment (PDNA) — jointly conducted by the government of Lesotho and its development partners - reports that Lesotho has been on the verge of a food security crisis, starting in the second half of 2011 through the summer crop harvest in 2012. The PDNA estimated recovery and reconstruction costs at M649 million (\$88 million). The total cost includes food imports and infrastructure repairs, resulting in overall flood-related imports of about $\$ 61$ million (2.4 percent of GDP).

Commodity price shocks are projected to exert a sizable impact on the balance of payments in 2011/12 and to a lesser extent in 2012/13. Oil imports are projected to grow by 30 percent in 2011/12 while food imports are projected to grow by 29 percent in value. The main drivers in both cases are increasing commodity prices while elevated prices of diamond exports somewhat bolstered the adverse impact of import prices. Assuming that commodity prices had grown at the rate expected at the time of program request as a counterfactual, staff estimates that increases in food and oil prices will result in a cost of about $\$ 83$ million in 2011/12 and 2012/13. When subtracting the higher value of diamond exports owing to diamond price increases, the net additional cost is $\$ 44$ million over the same period.

\section{Commodity price shocks and flood-related imports have weakened the balance of payments.} Flood related imports and the additional net cost of commodity prices put pressure on the balance of payments. Staff estimates that the total impact of the two exogenous shocks will be a loss of $\$ 105$ million (equivalent to 4.2 percent of GDP) in international reserves.

\begin{tabular}{|c|c|c|c|c|c|c|}
\hline & \multicolumn{3}{|c|}{ Millions of US\$ } & \multicolumn{3}{|c|}{ Percent of GDP } \\
\hline & $2011 / 12$ & $2012 / 13$ & Total & $2011 / 12$ & $2012 / 13$ & Total \\
\hline Total costs & 61 & 44 & 105 & 2.5 & 1.7 & 4.2 \\
\hline Net cost of high commodity prices ${ }^{1}$ & 28 & 16 & 44 & 1.1 & 0.6 & 1.7 \\
\hline Cost increase of food imports owing to price increase & 17 & 19 & 36 & 0.7 & 0.7 & 1.4 \\
\hline Cost increase of oil imports owing to price increase & 24 & 23 & 47 & 1.0 & 0.9 & 1.9 \\
\hline Value increase of diamond exports owing to price increase & 14 & 26 & 40 & 0.6 & 1.0 & 1.5 \\
\hline Flood related imports ${ }^{2}$ & 33 & 28 & 61 & 1.3 & 1.1 & 2.4 \\
\hline Reconstruction ${ }^{3}$ & 29 & 23 & 52 & 1.2 & 0.9 & 2.0 \\
\hline Recovery $^{3}$ & 4 & 5 & 9 & 0.2 & 0.2 & 0.4 \\
\hline
\end{tabular}

$1 /$ Based on the assumption that oil and food prices had grown at the rates forecast at time of program request.

2/ Assuming that flood related spending is fully executed (including the amount not yet budgeted for).

3/ Assuming $80 \%$ import content for reconstruction spending (public works and transport, agriculture and food security, construction and repair of schools) and $50 \%$ for recovery spending (subsidies on inputs, irrigation). 


\section{B. Policies to Achieve Sustained Growth in the Medium-Term}

Over the medium-term, to achieve the objective of "sustained economic growth as the most effective route for poverty reduction" the authorities plan to focus on lowering Lesotho's vulnerability to shocks and stepping up structural reforms to promote private sector development.

\section{Lowering Lesotho's vulnerability to external shocks}

\section{Sufficient international reserve cushion and sound debt management are} essential for lowering Lesotho's vulnerability to exogenous shocks. Lesotho has been particularly vulnerable to shocks because of its narrow production base and heavy reliance on SACU revenues. Looking back, Lesotho had successfully accumulated reserves covering 5-7 months of imports in 2007-09, providing an effective cushion against the recent drop in SACU revenues. Going forward, policy objective should be to maintain fiscal and debt sustainability. ${ }^{2}$ To prepare for future shocks, the authorities should aim at rebuilding an international reserves buffer of 5-7 months of imports. ${ }^{3}$

\section{Given the desirability of maintaining the peg, Lesotho will have to rely heavily} on fiscal adjustment to accumulate international reserves. Staff and the authorities agreed that the current pegged exchange rate regime has helped to anchor price stability while facilitating capital and current transactions with South Africa. ${ }^{4}$ In this context, staff urged that, to achieve an adequate reserves coverage, fiscal consolidation should be stepped up, with a view to achieving an overall fiscal surplus in 2012/13. The authorities agreed with this stance and committed to a fiscal consolidation effort over the medium term, anchored on achieving a surplus on the core-SACU

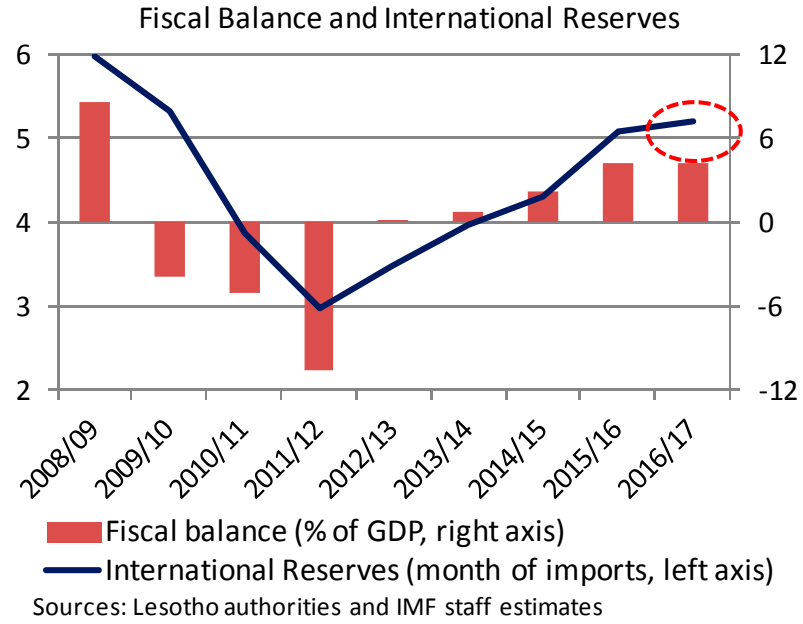
balance by $2015 / 16$.

\footnotetext{
${ }^{2}$ Based on a preliminary LIC DSA, Lesotho remains at moderate risk of debt distress. Debt ratios are projected to remain manageable over the medium-term as SACU revenues recover and the fiscal position improves.

3 This suggested range is broadly consistent with the estimated optimal reserves, based on a cost-benefit approach ("Optimal Precautionary Reserves for Low-Income Countries: A Cost-Benefit Analysis", IMF Working Paper, October 2011). Taking into account a country's exchange rate regime, its fiscal position and the presence of an IMF program, among other factors, the approach helps to quantify the optimal level of international reserves in low-income countries.

${ }^{4}$ In terms of the exchange rate, there is no clear indication of misalignment. Lesotho's real effective exchange rate (REER) appreciated gradually between the beginning of 2009 and end 2010, but has since depreciated somewhat. Exchange rate assessments based on several approaches suggest that the Loti is closed to its equilibrium value (Box 3).
} 
15. The authorities reaffirmed that the exchange rate peg has helped anchor macroeconomic and financial stability in Lesotho and agreed that fiscal restraint is needed to help sustain the peg. Medium-term fiscal consolidation would alleviate potential pressures on Lesotho's external balance. They argued that, as a low income country, the opportunity cost of holding excess reserves is high, given Lesotho's significant development needs. The challenge is to strike a fair balance between holding adequate reserves and undertaking capital spending for development. To prepare for future shocks, the authorities agreed with the medium-term objective of building up an international reserve cushion of a minimum of five months of imports.

\section{Box 3. Lesotho: Exchange Rate Assessment}

An exchange rate assessment exercise based on an adapted version of the IMF's Consultative Group on Exchange Rate Issues (CGER) methodology suggests that the Loti is close to its equilibrium value as of end-November 2011. The CGER methodology was adapted to cover sub-Saharan economies. ${ }^{1}$ Combining three approaches suggests that the Loti is broadly in line with its equilibrium value.

- $\quad$ The external sustainability approach assesses the level of the current account balance that would stabilize the country's net foreign asset position. It suggests that the Loti is about 4 percent overvalued.

- $\quad$ The equilibrium real exchange rate approach computes the real effective exchange rate (REER)'s percentage deviation from its equilibrium value determined on the basis of macroeconomic fundamentals. It suggests that the Loti is about 7 percent overvalued.

- The macroeconomic balance approach compares Lesotho's medium-term external current account to a country-specific norm based on macro fundamentals. It suggests that the Loti is about 4 percent undervalued.

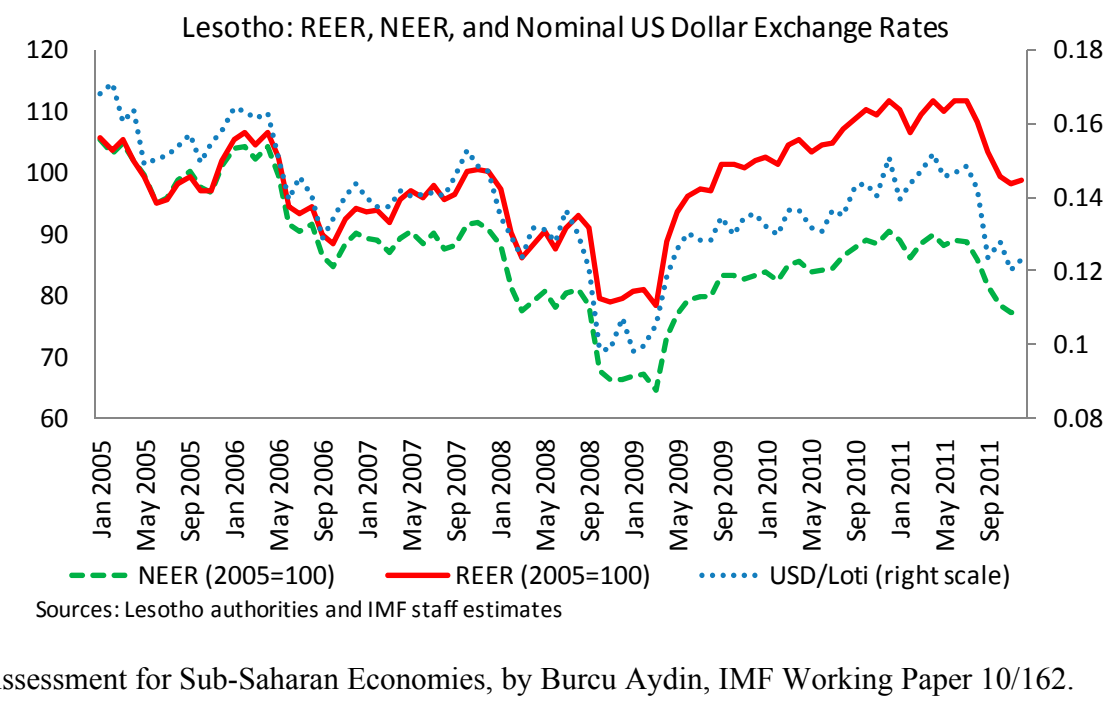

${ }^{1 /}$ Exchange rate Assessment for Sub-Saharan Economies, by Burcu Aydin, IMF Working Paper 10/162. 
16. To properly estimate the progress in fiscal adjustment in the presence of high volatility of SACU revenues, staff endorsed the authorities' proposal to explicitly target a core $S A C U$ fiscal balance. This core SACU fiscal balance is defined as the overall fiscal balance excluding the noncore component of SACU revenues and foreign-financed project loan. ${ }^{5}$ Going forward, the authorities agreed to use this concept as a fiscal policy anchor for their consolidation reforms with a view to reducing dependence on SACU revenues.

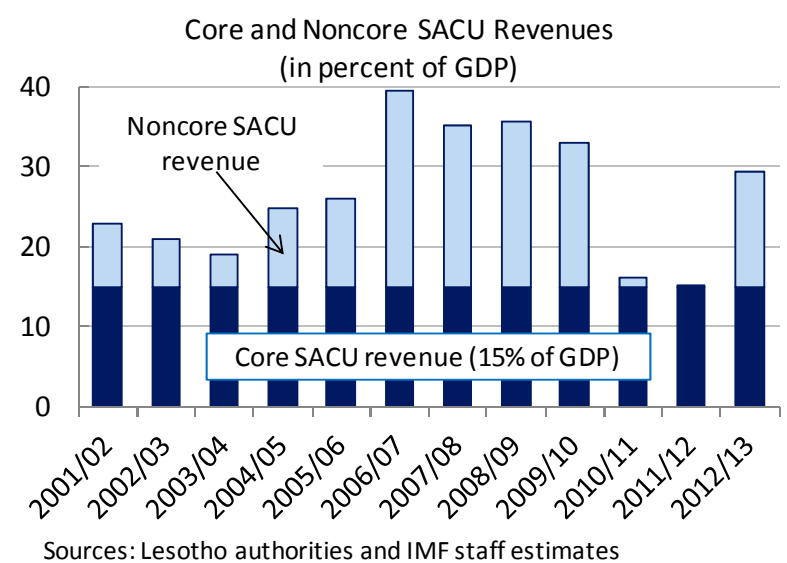

17. For 2012/13, while the SACU revenues will recover significantly, the authorities-maintaining their adjustment effort-are targeting a core SACU fiscal deficit of $81 / 2$ percent of GDP. This is slightly higher than the projected outcome for 2011/12

(MEFP $\mid 14$ ), because of the following spending needs:

- higher health care spending (1.8 percent of GDP) to keep the recently-built referral hospital and donor financed health clinics fully operational;

- higher old age pension payment (0.3 percent of GDP) to afford the minimum cost of living (about US\$47 per month);

- enhanced defense force to meet SADC requirements for a standby peace-keeping force ( 0.3 percent of GDP);

- additional cost of national elections in 2012 (0.3 percent of GDP) to ensure that they meet international standards for security, logistics and infrastructure; and

- deferred spending on flood-related rehabilitation ( 0.9 percent of GDP; Box 2).

Despite these additional spending needs, the authorities plan to contain overall expenditures

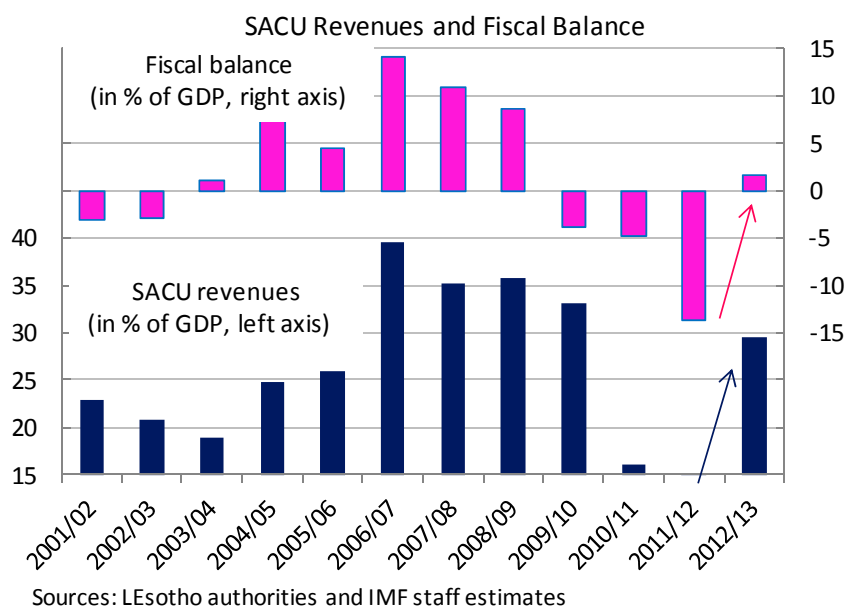

\footnotetext{
${ }^{5}$ Under this concept, SACU revenues are separated into two components: a core component (equivalent to 15 percent of GDP, which is the lowest annual SACU receipt in the last two decades) and a noncore component (the rest).
} 
through a combination of (i) restraining wages by restricting new positions in civil service, and keeping civil servant wages constant in real terms; and (ii) reducing non-priority outlays through stricter expenditure controls resulting from the effective implementation of the Integrated Financial Management Information System (IFMIS) (MEFP \14). With these adjustment efforts, as well as with an expected recovery in SACU revenues, the overall fiscal position is projected to be in balance by $2012 / 13$ - the first time since the crisis emerged in 2008/09.

18. These fiscal consolidation efforts in $2012 / 13$ will be maintained over the medium-term, with a view to reducing dependence on SACU revenues and rebuilding international reserves, Recurrent expenditures are projected to decline over time and the core SACU fiscal balance is expected to steadily improve (Table 3), and thereby help to rebuild sufficient international reserves.

\section{The fiscal stance is compatible with maintaining a moderate risk of debt distress} over the medium term. While the public debt to GDP ratio is projected to grow temporarily to $43-45$ percent of GDP on account of large infrastructure projects (including the Metolong Dam and under Lesotho Highlands Water Project Phase II), the risk of debt distress remains moderate. To help ensure debt sustainability, the authorities intend to formulate a debt management strategy and also continue to seek external financing through grants and concessional loans and save any unplanned inflows. $^{6}$

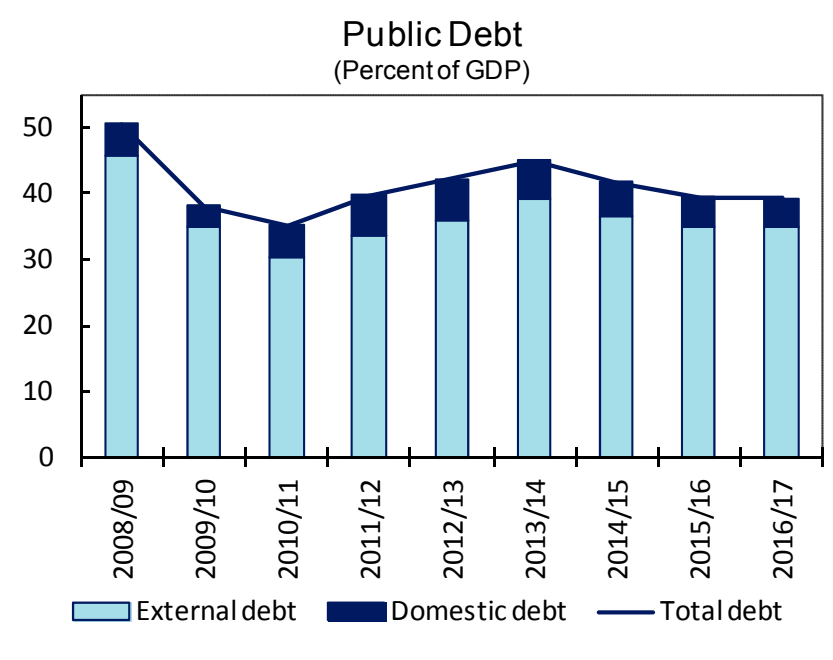

Sources: MoFDP and IMF staff estimates.

\section{Structural reforms to promote private sector development}

Discussions on structural measures addressed the array of reforms that may be needed to address high unemployment and inequality and to help diversify the economy.

\section{To achieve sustained growth and increase employment, private sector} development is important, as recognized in the National Strategic Development Plan

\footnotetext{
${ }^{6}$ As agreed under the program, nonconcessional financing will be used only for the Metolong Dam project. In addition, while spending commitments under Lesotho Highlands Water Project Phase II (LHWP2) remain uncertain and the authorities are assessing medium-term financing options, it is unlikely that financing will be available on concessional terms. Thus, provisions for additional nonconcessional financing may need to be considered in the future.
} 
(NSDP). The NSDP expects the private sector to be the engine of growth, while acknowledging an "uncompetitive business environment" as one of the most binding constraints to the sector. Specifically those constraints include; a high regulatory burden to open and close business and low access to credit. Among these constraints, the discussion focused on the approaches to enhance access to credit and improve the business environment.

World Bank Doing Business Indicators for Lesotho's Neighboring Countries (Ranking out of 183 countries)

\begin{tabular}{|l|c|c|c|c|c|c|c|c|}
\hline & $\begin{array}{c}\text { Ease of Doing } \\
\text { Business Rank }\end{array}$ & $\begin{array}{c}\text { Starting a } \\
\text { Business }\end{array}$ & $\begin{array}{c}\text { Dealing with } \\
\text { Construction Permits }\end{array}$ & $\begin{array}{c}\text { Registering } \\
\text { Property }\end{array}$ & $\begin{array}{c}\text { Getting } \\
\text { Credit }\end{array}$ & $\begin{array}{c}\text { Protecting } \\
\text { Investors }\end{array}$ & $\begin{array}{c}\text { Trading Across } \\
\text { Borders }\end{array}$ & $\begin{array}{c}\text { Enforcing } \\
\text { Contracts }\end{array}$ \\
\hline South Africa & 35 & 44 & 31 & 76 & 1 & 10 & 144 & 81 \\
\hline Botswana & 54 & 90 & 132 & 50 & 48 & 46 & 150 & 65 \\
\hline Namibia & 78 & 125 & 52 & 145 & 24 & 79 & 142 & 40 \\
\hline Swaziland & 124 & 161 & 47 & 128 & 48 & 122 & 148 & 171 \\
\hline Mozambique & 139 & 70 & 126 & 156 & 150 & 46 & 136 & 131 \\
\hline Lesotho & 143 & 144 & 157 & 150 & 150 & 147 & 147 & 102 \\
\hline Zimbabwe & 171 & 144 & 166 & 85 & 126 & 122 & 172 & 112 \\
\hline Angola & 172 & 167 & 115 & 129 & 126 & 65 & 163 & 181 \\
\hline
\end{tabular}

Source: World Bank the 2012 Doing Business Report

\section{The authorities continue to commit to implementing reforms to improve the} business climate to support private sector-led growth and economic diversification. The Industrial Licensing Bill (structural benchmark) is expected to improve the licensing process, further reducing delays and making the whole procedure transparent. The authorities have also made steady progress in promoting financial sector development by improving access to financial services, through a partial guarantee scheme and micro financial services (MEFP, ๆ17-18). Effective implementation of the new Financial Institutions Act (FIA) will help to reduce financial sector risks, covering nonbank financial institutions under the supervision by the CBL (Box 4). These reforms to support private sector-led growth and economic diversification are important for broad-based inclusive growth, leading to a recovery in national income after a long period of stagnation (Box 5). Furthermore, the authorities should continue to take steps to ensure the effective implementation of the recommendations made in the anti-money laundering and combating the financing of terrorism (AML/CFT) report of the Eastern and Southern Africa Anti-Money Laundering Group (ESAAMLG) in September 2011. ${ }^{7}$

\footnotetext{
${ }^{7}$ In particular, the authorities are encouraged to further operationalize the Financial Intelligence Unit (FIU), adequately criminalize money laundering and terrorist financing, introduce laws and regulations to implement United Nations Security Council Resolutions (UNSCRs) 1267 and 1373 and put in place the appropriate customer due diligence (CDD) and record-keeping requirements in the financial and non-financial sectors.
} 


\section{Box 4. Lesotho: Non-bank Financial Institutions}

Non-bank financial sector in Lesotho is diverse and made up of an ever expanding spectrum of deposit taking and non-deposit taking institutions varying in size, numbers and type of financial services they provide. It includes insurance companies; registered money lenders; credit only institutions; pension funds; collective investment schemes; asset management companies; exchange bureau; money transfers companies and insurance brokers and agents.

Lesotho: Bank and Nonbank Financial Institutions

\begin{tabular}{|c|c|c|c|c|}
\hline & \multicolumn{2}{|c|}{ Number } & \multicolumn{2}{|c|}{$\begin{array}{c}\text { Assets } \\
\text { (Percent of GDP) }\end{array}$} \\
\hline & 2007 & 2010 & 2007 & 2010 \\
\hline Banks & 4 & 4 & 42 & 47.3 \\
\hline Financial cooperatives & 160 & 51 & $\ldots$ & 0.4 \\
\hline Collective investment schemes & $\ldots$ & 4 & $\ldots$ & 2.5 \\
\hline Insurance companies & 4 & 7 & 18 & 14.2 \\
\hline Pension funds & $\ldots$ & 102 & 5 & 14.0 \\
\hline Money lenders & 13 & 57 & $\ldots$ & 0.4 \\
\hline Asset management companies & $\ldots$ & 2 & $\ldots$ & 0.1 \\
\hline Exchange bureaus & $\ldots$ & 2 & $\ldots$ & $\ldots$ \\
\hline Money transfer companies & $\ldots$ & 2 & $\ldots$ & $\ldots$ \\
\hline Insurance brokers and agents & 8 & 8 & $\ldots$ & $\ldots$ \\
\hline
\end{tabular}

The overall assets of the non-bank financial institutions (NBFIs), as a whole, are significant, standing at 31.7 percent of GDP in 2010, with insurance and pension funds being the two largest subsectors each with asset size at 14 percent of GDP. The sector grew by 8.7 percent of GDP from 2007 to 2010 , faster than the pace (5.3 percent of GDP) of the formal commercial banking sector in the same period. The number of operative NBFIs in 2010 reached 235, compared with 185 in 2007.

A key challenge for the sector going forward relates to its proper regulation and supervision. While the banking sector (made up mainly of subsidiaries of South African parents' banks) has been well regulated and supervised, the NBFIs were generally not comprehensively supervised. This void has been filled through the implementation of the Financial institutions Act (FIA), an umbrella legislation which will guide all aspects of regulations and supervision of both bank and non-bank financial institutions. Currently all these regulations are being updated in line with the FIA, stepped-up efforts are required to strengthen supervisory capacity to properly implement the FIA. 


\section{Box 5. Lesotho: Disparity in GNI and GDP}

Whereas Gross National Product (GDP) is a measure of national income/output produced in a particular country, Gross National Income (GNI) also includes the net factor income from abroad such as dividends, interest and profits.

In Lesotho, GNI has stagnated for the last few decades, despite steady GDP growth. GNI per capita grew at an annual average of only 1 percent a year between 2001 and 2010, compared with real GDP growth of about 4 percent over the same period. The World Bank (Lesotho: Third Poverty Reduction Support Grant and Credit Program, May 31, 2011) pointed that, despite good economic growth, inequality (Gini coefficient of 0.66) and unemployment (22.7 percent in 2008) stay high, suggesting that the benefits of growth have not easily reached the poor. This highlights a uniqueness of the Lesotho economy-compared with other countries in the region-where worker remittances have declined systematically over time. While Lesotho has a relatively high proportion of its labor force employed outside the country, the number of Basotho workers in the mines of South Africa has declined, partly because of a shift toward the use of South Africa's local labor.

The stagnation of GNI reflects changes in net factor income over the years, with the gains in GDP partially offset by falling remittances of mine workers. In the 1980s, Lesotho received twice as much GDP in remittances from Lesotho migrant workers employed in South Africa. Meanwhile, income payments to the rest of the world were less than 10 percent of GDP. In recent years, however, remittances have declined to about a half of GDP owing to retrenchments of Lesotho mine workers in South Africa, while income payments are increasing, partly driven by dividend payments to mining and textile companies. As a result, domestic production (GDP) has steadily
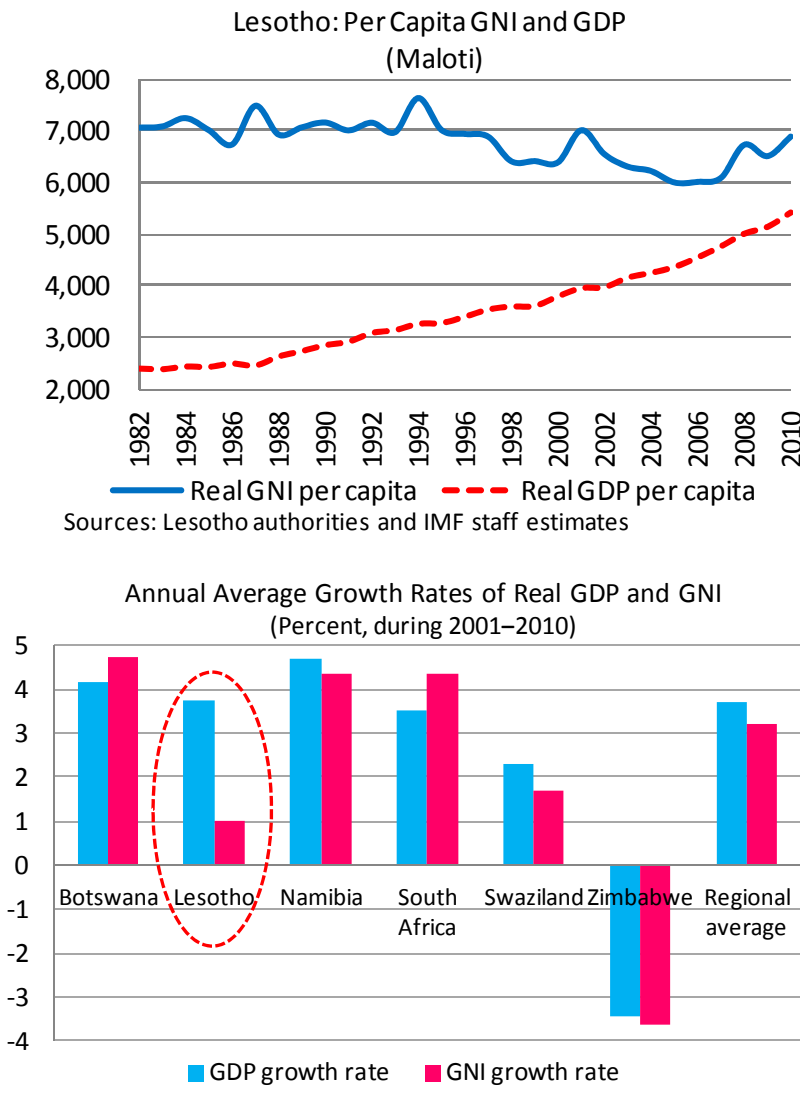

Sources: Country authorities and IMF staff estimates

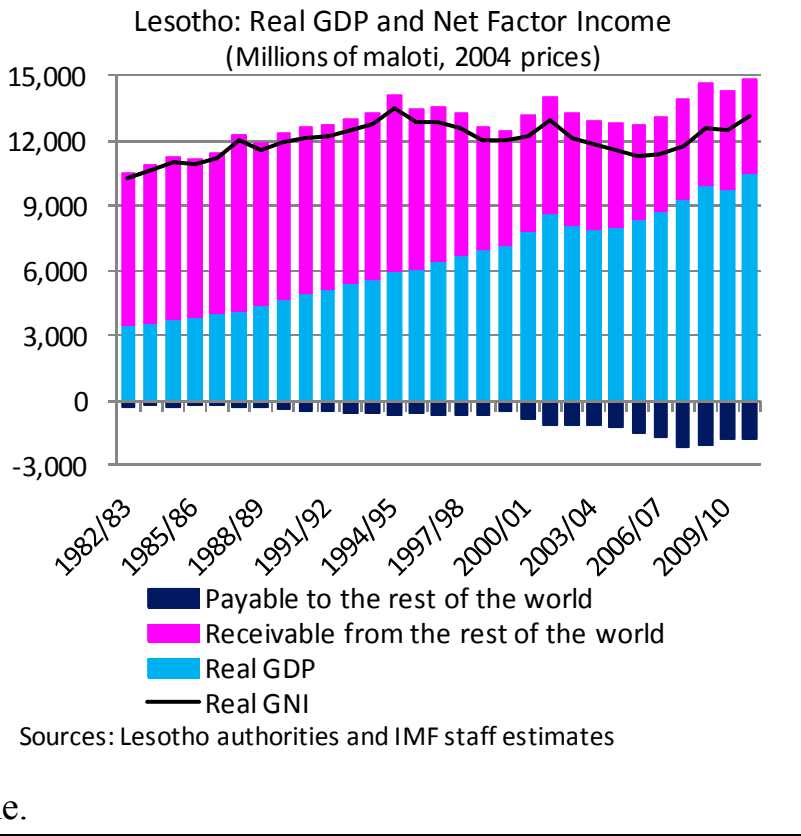




\section{Medium-term Outlook}

\section{The baseline medium-term economic outlook for Lesotho is favorable but downside risks remain.}

- The baseline scenario assumes continued fiscal consolidation and stepped-up structural reforms, in line with the NSDP. Real GDP growth will average about $4 \frac{1}{2}$ percent a year for 2012/13-2016/17. With steady progress in fiscal consolidation efforts, gradual replenishment of gross official international reserves is expected to bring import coverage to five months of imports by 2015/16.

\begin{tabular}{|c|c|c|c|c|c|c|c|}
\hline \multicolumn{8}{|c|}{$\begin{array}{c}\text { Medium-Term Projections (Baseline) } \\
\text { (Percent of GDP, unless otherwise indicated) }\end{array}$} \\
\hline & $2010 / 11$ & $2011 / 12$ & $012 / 13$ & $2013 / 14$ & $2014 / 15$ & $2015 / 16$ & $2016 / 17$ \\
\hline & Act. & Proj. & Proj. & Proj. & Proj. & Proj. & Proj. \\
\hline GDP growth (annual change) & 5.7 & 4.2 & 5.2 & 2.2 & 5.9 & 6.3 & 3.1 \\
\hline Consumer price (period average, annual change) & 3.4 & 5.6 & 5.2 & 4.6 & 4.6 & 4.6 & 4.7 \\
\hline Fiscal balance & -5.0 & -10.5 & 0.2 & 0.7 & 2.2 & 4.3 & 4.3 \\
\hline Fiscal balance (excluding SACU revenue) & -21.2 & -25.6 & -28.8 & -24.2 & -19.6 & -16.5 & -15.0 \\
\hline Total revenue & 52.5 & 51.6 & 65.5 & 58.6 & 51.9 & 52.0 & 50.9 \\
\hline Domestic revenue & 29.0 & 27.9 & 27.5 & 28.2 & 27.3 & 27.7 & 28.7 \\
\hline SACU revenue & 16.1 & 15.2 & 29.0 & 24.9 & 21.8 & 20.8 & 19.2 \\
\hline External grants & 7.4 & 8.5 & 9.0 & 5.4 & 2.7 & 3.4 & 3.0 \\
\hline Total expenditure & 57.5 & 62.1 & 65.3 & 57.8 & 49.7 & 47.7 & 46.7 \\
\hline Recurrent expenditure & 39.1 & 41.4 & 40.7 & 38.7 & 36.2 & 32.5 & 31.6 \\
\hline Capital expenditure & 18.4 & 20.7 & 24.6 & 19.1 & 13.5 & 15.2 & 15.1 \\
\hline Current account balance (including grants) & -14.8 & -16.6 & -11.2 & -15.4 & -5.8 & 1.6 & 1.3 \\
\hline Gross international reserves (month of imports) & 3.9 & 3.0 & 3.5 & 4.0 & 4.3 & 5.1 & 5.2 \\
\hline Total debt & 35.2 & 39.6 & 42.2 & 45.0 & 41.7 & 39.4 & 39.2 \\
\hline External debt & 30.4 & 33.7 & 35.9 & 39.1 & 36.5 & 34.9 & 35.0 \\
\hline Domestic debt & 4.8 & 6.0 & 6.3 & 5.9 & 5.2 & 4.5 & 4.2 \\
\hline
\end{tabular}

Sources: Lesotho authorities and IMF staff estimates

\section{Although the macroeconomic objectives and the strategy laid out are} appropriate, the medium-term outlook is clouded with significant downside risks. Specifically, in the face of uncertain global economic environments, Lesotho faces a risk of fall in SACU revenues and unexpected decline in global demand for diamond. ${ }^{89}$

\footnotetext{
${ }^{8}$ With new mines coming on stream, diamond production (which accounts for about 8 percent of GDP) is projected to exceed 20 percent of GDP by 2016/17. This projection, however, posed high risk because of uncertain prospects for global demand for diamond.

${ }^{9}$ SACU revenues have proven to be very volatile. The sharp drop in 2010/11-2011/12 is the result of repayments to the Common Revenue Pool (CRP) totalling some 14 percent of GDP, owing to overpayments of the revenues for 2008/09 and 2009/10, when South Africa's imports were affected by the global economic crisis. Increases in subsequent years reflect the combination of projected increases in the CRP owing to largerthan-expected increases in custom duties and excise taxes by South Africa, and the absence of any repayment
}

(continued...) 
24. Possible implications of a deteriorating global economic outlook were discussed, including taking additional adjustment measures, as needed, in the event of a deep global economic slowdown. Based on the baseline scenario above, an alternative mediumterm scenario assumes the impacts of a possible global economic slowdown in 2012/132013/14 (similar to that experienced in 2008-09), with lower diamond production and SACU revenues. Lesotho's average growth rate would be lowered by about 1 percent during the period. With no additional adjustment effort (on top of what is envisaged under the baseline scenario), the fiscal balance would be worsened by 7-10 percent of GDP, and international reserves would fall to about 1 month of imports by 2014/15. The staff advised the authorities to stay vigilant on Lesotho's external environments and be prepared to take additional adjustment measures. In the event of such a shock, additional fiscal tightening would be required. The authorities appreciated the staff's sensitivity analysis and underscored the need to prepare for further shocks.

Sensitivity Analysis: Medium-term Projections (Risk Scenario)

(Percent of GDP, unless otherwise indicated)

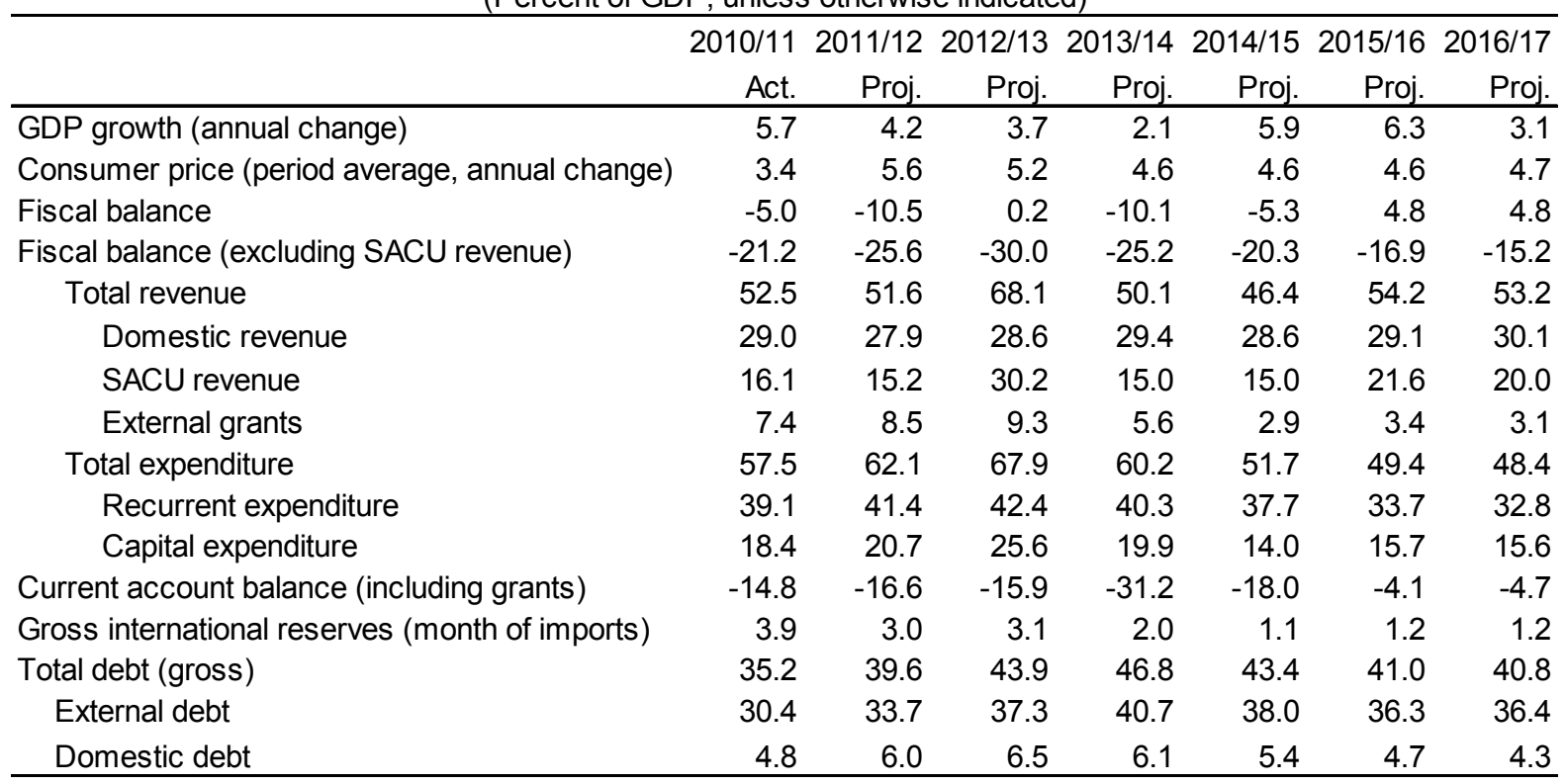

Sources: Lesotho authorities and IMF staff estimates

\section{Program Monitoring, Poverty Reduction Strategy, and Safeguards} ASSESSMENT

\section{A. Case for Augmentation}

\section{The authorities have requested an augmentation of access under the ECF arrangement in amount equivalent to SDR8.73 million (25 percent of quota to be}

by Lesotho to the CRP. Should the imports decline in 2012/13, the revenue flows in 2013/14 and beyond could be affected. 
disbursed with the third and fourth tranches under the program) to help maintain an adequate level of international reserves. ${ }^{10}$ It would complement Lesotho's domestic adjustment efforts and additional donor support. The need for the augmentation reflect the following:

- Following a sharp fall in SACU revenues in 2010/11 and 2011/12, new shocks (floods and high commodity prices) have put additional pressure on fiscal and external balances.

- The augmentation would help achieve an adequate level of international reserves in support of Lesotho's exchange rate peg to the South African rand. Lesotho's international reserves would recover to about 31/2 months of imports by end-March 2013.

- The augmentation is part of a concerted effort by development partners to address the recent shocks. A few development partners have already offered some assistance. ${ }^{11}$ The proposed augmentation would add some US\$14 million, equivalent to 0.5 percent of GDP to mitigate the impact of the shocks on international reserves. The authorities are also seeking financial support from other partners, and expecting that the IMF's decision on the augmentation will catalyze additional resources.

- Lesotho has a good policy track record, as evidenced by the stronger-than-programmed fiscal adjustment in 2010/11. It has responded prudently to the recent shocks, avoided policies that cause economic distortions, and focused instead on social impact mitigation and measures to boost food supply.

- For 2011/12, the authorities have further strengthened their adjustment efforts as evidenced by reprioritization of spending allowing for a significant under-execution of the budget. The revised economic program includes an appropriate domestic adjustment effort, and thus, despite the additional costs for flood-related damage, the authorities are committed to containing the core-SACU fiscal deficit of 2011/12 at a level much lower than the level agreed to during the first review of the ECF-supported program.

- Lesotho's capacity to repay the IMF would remain strong, supported by the authorities' solid record of debt repayment. The augmentation would not materially affect debt sustainability indicators.

\footnotetext{
${ }^{10}$ The financing requirement for 2011/12 will be financed mainly by SACU transfers, and loans and grants from development partners, and drawdown of reserves. With significant increase in SACU revenues and exports, the overall balance is expected to improve in 2012/13. The ECF-supported program is projected to be fully financed for the remainder of the program period.

${ }^{11}$ The UN, UNDP, Ireland, People's Republic of China, and OCHA have pledged the total of US\$2.8 million for the Disaster Risk Reduction Fund (DRRF). Following the preparation of operational guidelines for the DRRF in November 2011, the Fund will become operational in 2012/13.
} 


\section{B. Program Monitoring}

26. The performance criteria (PCs) and benchmarks are proposed as shown in MEFP, Table 1. Completion of the fourth, fifth, and sixth reviews of the arrangement by August 20, 2012, February 20, 2013, and May 20, 2013, respectively, will be based on the observance of quantitative PCs through end-March 2012, end-September 2012, and endMarch 2013, respectively (MEFP, Table 1). The targets for end-June 2012 and endDecember 2012 will be indicative. Structural benchmarks have been established through endDecember 2012 (MEFP, Table 3). The definitions of the variables monitored as quantitative PCs are provided in the Technical Memorandum of Understanding (TMU), Appendix I, Attachment 2.

\section{Poverty Reduction Strategy}

27. The authorities, supported by development partners, have recently finalized a comprehensive five-year National Strategic Development Plan (NSDP) covering 2012/13-2016/17. The NSDP, prepared following extensive nationwide public consultation, has been submitted to the Boards of the IMF and the World Bank. It emphasizes the need to achieve sustained economic growth as the most effective route for poverty reduction and also to deliver sound macroeconomic management. In support of the macroeconomic policy objectives, the NSDP aims at: providing an attractive environment for foreign and domestic investment; encouraging domestic saving and foreign capital inflow; ensuring sustainable levels of fiscal deficit and public debt; ensuring low and sustainable inflation; maintaining sound external balances; and setting tax and expenditure policies that contribute to improving the distribution of income and wealth.

\section{Staff welcomed the NSDP's focus on sustained economic growth while ensuring} sound, stable macroeconomic management and promoting structural reforms, in line with the objectives of the ECF-supported program. To this end, the NSDP - among other things - underlines the need for fiscal consolidation, with a view to achieving an overall fiscal surplus during the NSDP period. The medium-term fiscal framework of the NSDP is less optimistic in terms of revenue projections than the fiscal framework under the ECFsupported program. ${ }^{12}$ The NSDP — in highlighting the impact of key structural reforms - also explores various growth scenarios, with average GDP growth of 1.5 percent under the low growth scenario, 5.8 percent under the moderate scenario and 6.7 percent under the Plan scenario. For the purpose of the ECF-supported program and the budget, however, a more conservative assumption (with average growth of 4.5 percent during 2012/13 and 2016/17) is maintained. To help achieve high growth, the NSDP focuses on structural reforms in broad

\footnotetext{
${ }^{12}$ Under the NSDP, assumption on mining dividends and water royalty collections are conservative relative to the program assumptions. The program reflects updated revenue data with higher dividends and water royalties in recent months, which are expected to continue over the medium-term.
} 
areas, such as improving the investment climate and promoting financial intermediation. The joint staff advisory note (JSAN) will be prepared by July 2012.

\section{Safeguards Assessment}

29. The CBL has made substantial progress in implementing the 2010 safeguards recommendations. Following the appointment of Deloitte (South Africa) as the CBL's sole external auditor in 2010, the audit of that year was completed within the three-month statutory deadline and the audited financial statements were published in full on the CBL's website by mid-April 2011. Deloitte (South Africa) has been reappointed to conduct the 2011 external audit jointly with a local audit firm. It is expected that the audit will be completed by end-March 2012. As recommended by the assessment, the CBL has also introduced internal audits of monetary data submitted for program monitoring purposes. The authorities are aware that in the event of an augmentation of the existing arrangement, an updated assessment would need to be completed.

\section{Staff Appraisal}

30. Despite new shocks, program performance has been strong. In 2010/11 and the first three quarters of $2011 / 12$, the authorities made substantial progress on fiscal consolidation, by reducing the overall fiscal deficit compared to the program target. This strong fiscal performance - supported by progress in structural reforms - has served well to limit the current account deficit, leading to higher-than-programmed accumulation of international reserves.

\section{For the remainder of 2011/12, strong fiscal discipline should remain in place.}

Despite additional spending needs, the overall deficit is expected to be contained below the level agreed to during the first review of the ECF-supported program. Staff welcomes the authorities' commitment to staying the course on fiscal consolidation, largely through reducing non priority expenditure. To help achieve the fiscal target, fiscal restraint must be supported by further strengthening PFM and revenue administration.

\section{Lesotho's medium-term economic outlook is favorable, though clouded by} significant downside risks. Economic growth is expected to be robust, because of an expanding mining sector and externally financed investment projects. However, Lesotho faces the risk of fall in SACU revenues and of an unexpected decline in global demand for diamond. Medium-term growth prospects therefore depend critically on ongoing reforms to improve the business environment and upgrade the physical infrastructure to aid in economic diversification. Staff also encourages the authorities to stay vigilant on the developments in Lesotho's external environments.

\section{Over the medium term, stepped-up fiscal adjustment efforts are therefore} crucial to ensure fiscal and external sustainability, while protecting spending for vulnerable groups and creating space for critical infrastructure investment. Staff encourages the authorities to maintain adjustment efforts in order to rebuild international reserves and 
place the country in a better position to respond to future shocks. To prepare for future shocks, the authorities should build an international reserve cushion of 5-7 months of imports. In the event of a global economic slowdown, additional adjustment measures should be implemented swiftly to alleviate potential pressures on Lesotho's external balance.

34. While the exchange rate seems to be broadly in line with its equilibrium rate, further progress in structural reforms is called for to improve external competitiveness. Analysis of the real exchange rate suggests there is no clear indication of misalignment, while further structural reforms would help strengthen competitiveness. To this end, fasttracking of the reforms will improve the business climate and productivity, and will enable Lesotho to overcome a number of its developmental challenges, including diversifying the economy, achieving broad-based sustained growth, and reducing poverty. Preparation of a new five-year NSDP provides an opportunity for the authorities to reevaluate their priorities and refocus efforts on enhancing Lesotho's long-term growth potential and ensuring job creation.

35. Staff welcomes progress made in strengthening the supervisory and framework for banks and nonbank financial institutions. The measures are critical for mitigating financial sector risks. Staff encourages the authorities' to strengthen their efforts in restructuring the $\mathrm{CBL}$ and building its capacity to effectively implement the new FIA. Improving the access to financial services will enhance financial deepening and support economic development.

36. The data provided to the IMF are adequate for surveillance and program monitoring purposes, but statistical weaknesses persist, most notably with regard to the national accounts and balance of payments. IMF technical assistance is being targeted on these areas.

37. Based on Lesotho's strong performance thus far and the authorities' continued commitment to maintaining fiscal consolidation, staff recommends completion of the second and third reviews under the three-year ECF arrangement, and the augmentation of access to resources under the arrangement by an amount of SDR 8.73 million (equivalent to 25 percent of quota). Risks to the program can be mitigated by sound policies and reforms, in coordination with Lesotho's development partners. Staff recommends a single disbursement of the proposed augmentation, in view of (i) immediate needs to rehabilitate flood-related damages and to address commodity price shocks on the balance of payments and (ii) the current low level of international reserve coverage.

38. Staff recommends that the next Article IV consultation with Lesotho be held on the 24-month consultation cycle. 
Table 1. Lesotho: Selected Economic Indicators, 2009/10-16/17

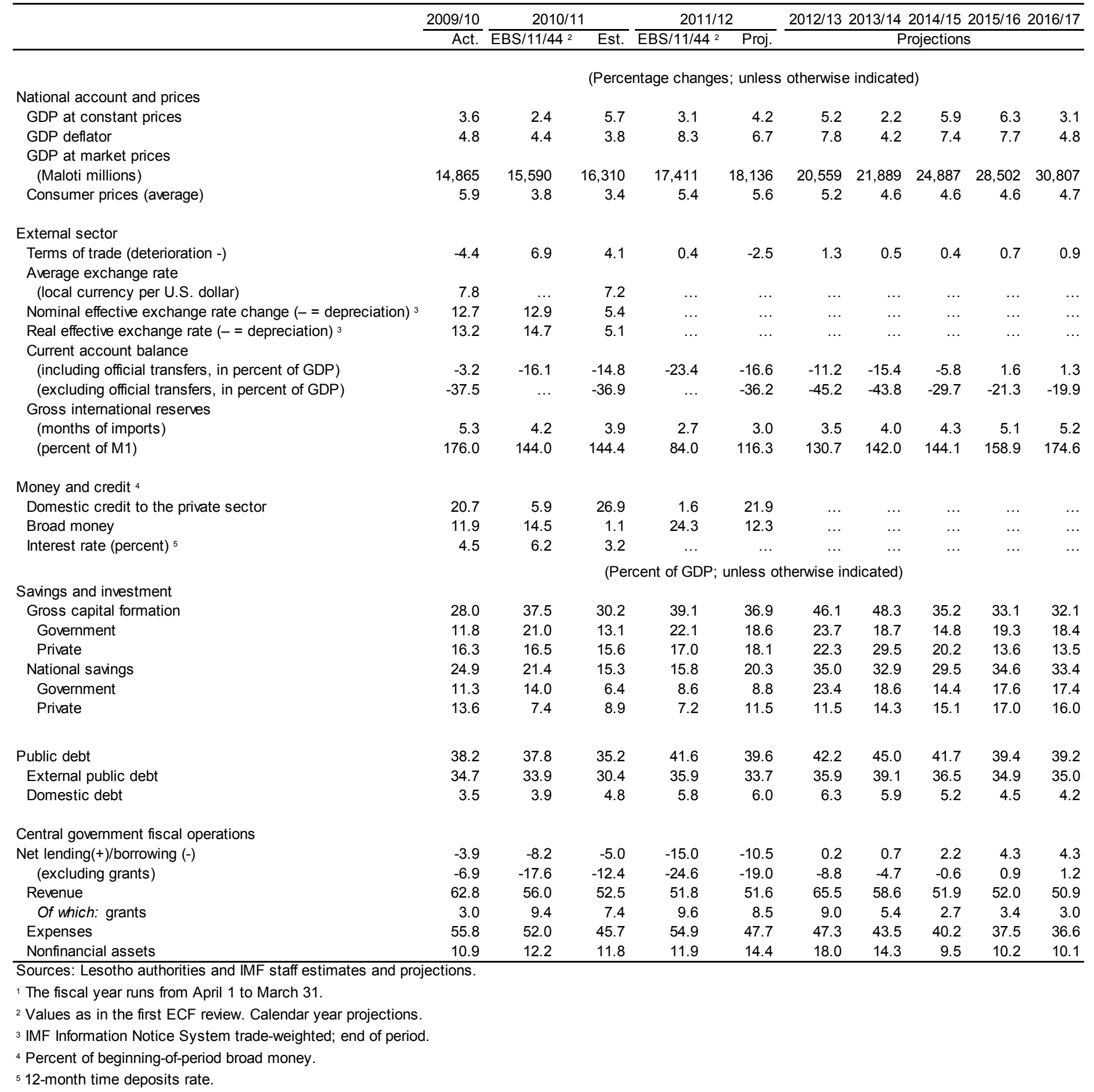


Table 2. Lesotho: Fiscal Operations of the Central Government, 2009/10-16/17 ${ }^{1}$ (Maloti millions)

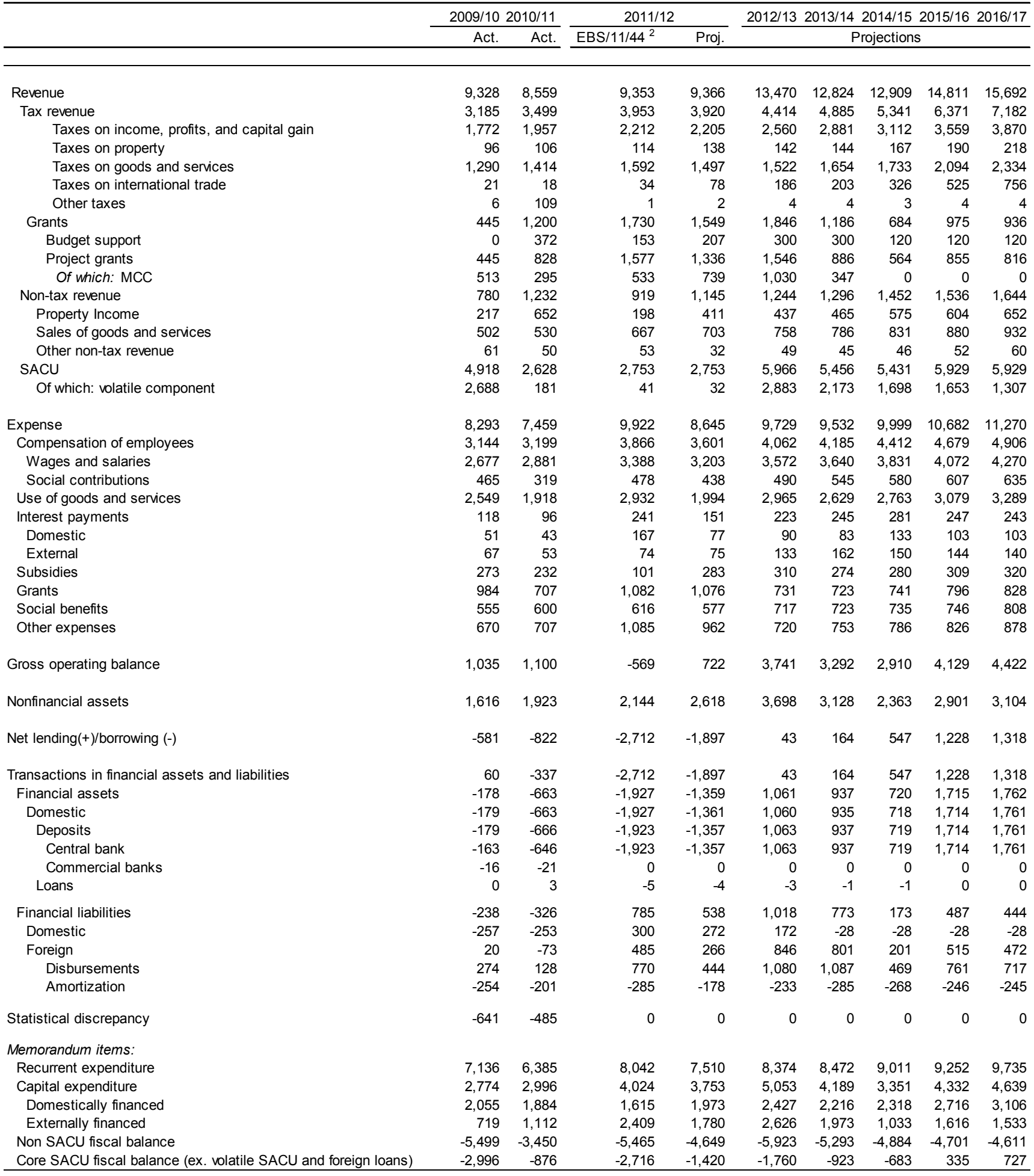

Sources: Lesotho authorities and IMF staff estimates and projections.

${ }^{1}$ The fiscal year runs from April 1 to March 31.

${ }^{2}$ Values as in the first ECF review. 
Table 3. Lesotho: Fiscal Operations of the Central Government, 2009/10-16/17 ${ }^{1}$ (Percent of GDP)

\begin{tabular}{|c|c|c|c|c|c|c|c|c|c|}
\hline \multirow{3}{*}{ Revenue } & \multirow{3}{*}{$\begin{array}{r}\frac{2009 / 10}{\text { Act. }} \\
62.8\end{array}$} & \multirow{3}{*}{$\begin{array}{r}\frac{2010 / 11}{\text { Act. }} \\
52.5\end{array}$} & \multicolumn{2}{|c|}{$2011 / 12$} & \multirow{3}{*}{$\begin{array}{r}2012 / 13 \\
65.5\end{array}$} & \multirow{2}{*}{\multicolumn{2}{|c|}{$\begin{array}{r}2013 / 142014 / 15 \\
\text { Projections }\end{array}$}} & \multirow{2}{*}{$2015 / 16$} & \multirow{3}{*}{$\begin{array}{r}2016 / 17 \\
50.9\end{array}$} \\
\hline & & & \multirow{2}{*}{$\begin{array}{r}\mathrm{EBS} / 11 / 44^{2} \\
51.8\end{array}$} & \multirow{2}{*}{$\begin{array}{l}\text { Proj. } \\
51.6\end{array}$} & & & & & \\
\hline & & & & & & 58.6 & 51.9 & 52.0 & \\
\hline Tax revenue & 21.4 & 21.5 & 21.9 & 21.6 & 21.5 & 22.3 & 21.5 & 22.4 & 23.3 \\
\hline Taxes on income, profits, and capital gain & 11.9 & 12.0 & 12.2 & 12.2 & 12.5 & 13.2 & 12.5 & 12.5 & 12.6 \\
\hline Taxes on property & 0.6 & 0.6 & 0.6 & 0.8 & 0.7 & 0.7 & 0.7 & 0.7 & 0.7 \\
\hline Taxes on goods and services & 8.7 & 8.7 & 8.8 & 8.3 & 7.4 & 7.6 & 7.0 & 7.3 & 7.6 \\
\hline Taxes on international trade & 0.1 & 0.1 & 0.2 & 0.4 & 0.9 & 0.9 & 1.3 & 1.8 & 2.5 \\
\hline Grants & 3.0 & 7.4 & 9.6 & 8.5 & 9.0 & 5.4 & 2.7 & 3.4 & 3.0 \\
\hline Budget Support & 0.0 & 2.3 & 0.8 & 1.1 & 1.5 & 1.4 & 0.5 & 0.4 & 0.4 \\
\hline Project grants & 3.0 & 5.1 & 8.7 & 7.4 & 7.5 & 4.0 & 2.3 & 3.0 & 2.7 \\
\hline Of which: MCC & 3.5 & 1.8 & 2.9 & 4.1 & 5.0 & 1.6 & 0.0 & 0.0 & 0.0 \\
\hline Non-tax revenue & 5.3 & 7.6 & 5.1 & 6.3 & 6.0 & 5.9 & 5.8 & 5.4 & 5.3 \\
\hline Property income & 1.5 & 4.0 & 1.1 & 2.3 & 2.1 & 2.1 & 2.3 & 2.1 & 2.1 \\
\hline Sales of goods and services & 3.4 & 3.3 & 3.7 & 3.9 & 3.7 & 3.6 & 3.3 & 3.1 & 3.0 \\
\hline Other non-tax revenue & 0.4 & 0.3 & 0.3 & 0.2 & 0.2 & 0.2 & 0.2 & 0.2 & 0.2 \\
\hline SACU & 33.1 & 16.1 & 15.2 & 15.2 & 29.0 & 24.9 & 21.8 & 20.8 & 19.2 \\
\hline Of which: volatile component & 18.1 & 1.1 & 0.2 & 0.2 & 14.0 & 9.9 & 6.8 & 5.8 & 4.2 \\
\hline Expense & 55.8 & 45.7 & 54.9 & 47.7 & 47.3 & 43.5 & 40.2 & 37.5 & 36.6 \\
\hline Compensation of employees & 21.1 & 19.6 & 21.4 & 19.9 & 19.8 & 19.1 & 17.7 & 16.4 & 15.9 \\
\hline Wages and salaries & 18.0 & 17.7 & 18.7 & 17.7 & 17.4 & 16.6 & 15.4 & 14.3 & 13.9 \\
\hline Social contributions & 3.1 & 2.0 & 2.6 & 2.4 & 2.4 & 2.5 & 2.3 & 2.1 & 2.1 \\
\hline Use of goods and services & 17.1 & 11.8 & 16.2 & 11.0 & 14.4 & 12.0 & 11.1 & 10.8 & 10.7 \\
\hline Interest payments & 0.8 & 0.6 & 1.3 & 0.8 & 1.1 & 1.1 & 1.1 & 0.9 & 0.8 \\
\hline Domestic & 0.3 & 0.3 & 0.9 & 0.4 & 0.4 & 0.4 & 0.5 & 0.4 & 0.3 \\
\hline External & 0.4 & 0.3 & 0.4 & 0.4 & 0.6 & 0.7 & 0.6 & 0.5 & 0.5 \\
\hline Subsidies & 1.8 & 1.4 & 0.6 & 1.6 & 1.5 & 1.3 & 1.1 & 1.1 & 1.0 \\
\hline Grants & 6.6 & 4.3 & 6.0 & 5.9 & 3.6 & 3.3 & 3.0 & 2.8 & 2.7 \\
\hline Social benefits & 3.7 & 3.7 & 3.4 & 3.2 & 3.5 & 3.3 & 3.0 & 2.6 & 2.6 \\
\hline Other expenses & 4.5 & 4.3 & 6.0 & 5.3 & 3.5 & 3.4 & 3.2 & 2.9 & 2.8 \\
\hline Gross operating balance & 7.0 & 6.7 & -3.1 & 4.0 & 18.2 & 15.0 & 11.7 & 14.5 & 14.4 \\
\hline Non-financial assets & 10.9 & 11.8 & 11.9 & 14.4 & 18.0 & 14.3 & 9.5 & 10.2 & 10.1 \\
\hline Net lending $(+) /$ borrowing (-) & -3.9 & -5.0 & -15.0 & -10.5 & 0.2 & 0.7 & 2.2 & 4.3 & 4.3 \\
\hline Transactions in financial assets and liabilities & 0.4 & -2.1 & -15.0 & -10.5 & 0.2 & 0.7 & 2.2 & 4.3 & 4.3 \\
\hline Financial assets & -1.2 & -4.1 & -10.7 & -7.5 & 5.2 & 4.3 & 2.9 & 6.0 & 5.7 \\
\hline Domestic & -1.2 & -4.1 & -10.7 & -7.5 & 5.2 & 4.3 & 2.9 & 6.0 & 5.7 \\
\hline Deposits & -1.2 & -4.1 & -10.6 & -7.5 & 5.2 & 4.3 & 2.9 & 6.0 & 5.7 \\
\hline Central bank & -0.1 & -4.0 & -10.6 & -7.5 & 5.2 & 4.3 & 2.9 & 6.0 & 5.7 \\
\hline Commercial banks & -1.1 & -0.1 & 0.0 & 0.0 & 0.0 & 0.0 & 0.0 & 0.0 & 0.0 \\
\hline Loans & 0.0 & 0.0 & 0.0 & 0.0 & 0.0 & 0.0 & 0.0 & 0.0 & 0.0 \\
\hline Financial liabilities & -1.6 & -2.0 & 4.3 & 3.0 & 5.0 & 3.5 & 0.7 & 1.7 & 1.4 \\
\hline Domestic & -1.7 & -1.6 & 1.7 & 1.5 & 0.8 & -0.1 & -0.1 & -0.1 & -0.1 \\
\hline Foreign & 0.1 & -0.4 & 2.7 & 1.5 & 4.1 & 3.7 & 0.8 & 1.8 & 1.5 \\
\hline Disbursements & 1.8 & 0.8 & 4.3 & 2.4 & 5.3 & 5.0 & 1.9 & 2.7 & 2.3 \\
\hline Amortization & -1.7 & -1.2 & -1.6 & -1.0 & -1.1 & -1.3 & -1.1 & -0.9 & -0.8 \\
\hline Statistical discrepancy & -4.3 & -3.0 & 0.0 & 0.0 & 0.0 & 0.0 & 0.0 & 0.0 & 0.0 \\
\hline Memorandum item: & & & & & & & & & \\
\hline Recurrent expenditure & 47.5 & 39.1 & 44.5 & 41.4 & 40.7 & 38.7 & 36.2 & 32.5 & 31.6 \\
\hline Capital expenditure & 18.7 & 18.4 & 22.3 & 20.7 & 24.6 & 19.1 & 13.5 & 15.2 & 15.1 \\
\hline Domestically financed & 13.8 & 11.6 & 8.9 & 10.9 & 11.8 & 10.1 & 9.3 & 9.5 & 10.1 \\
\hline Externally financed & 4.8 & 6.8 & 13.3 & 9.8 & 12.8 & 9.0 & 4.2 & 5.7 & 5.0 \\
\hline Non SACU fiscal balance & -37.0 & -21.2 & -30.2 & -25.6 & -28.8 & -24.2 & -19.6 & -16.5 & -15.0 \\
\hline Core SACU fiscal balance (ex. volatile SACU and foreign loans) & -20.2 & -5.4 & -15.0 & -7.8 & -8.6 & -4.2 & -2.7 & 1.2 & 2.4 \\
\hline
\end{tabular}

Sources: Lesotho authorities and IMF staff estimates and projections.

${ }^{1}$ The fiscal year runs from April 1 to March 31.

2 Values as in the first ECF review. 
Table 4. Lesotho: Monetary Accounts, 2009-13 1,2

(Maloti millions; unless otherwise indicated)

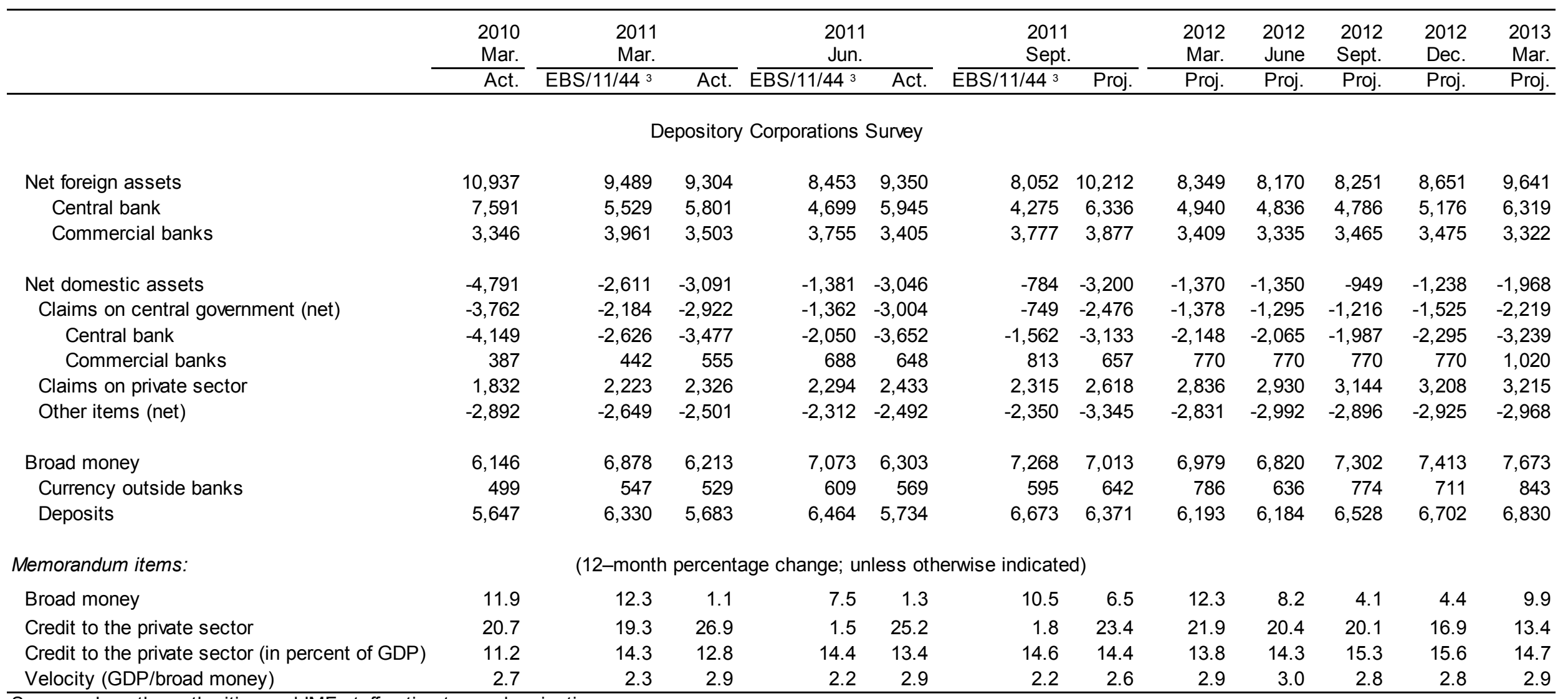

Sources: Lesotho authorities and IMF staff estimates and projections.

1 The fiscal year runs from April 1 to March 31.

2 Including valuation changes.

${ }^{3}$ Values as in the first ECF review. 
Table 5. Lesotho: Balance of Payments, 2009/10-16/17

(US\$ millions; unless otherwise indicated)

\begin{tabular}{|c|c|c|c|c|c|c|c|c|c|c|c|c|}
\hline \multirow{3}{*}{ Current account } & \multirow{3}{*}{$\begin{array}{r}2009 / 10 \\
\text { Act. } \\
-60\end{array}$} & \multicolumn{3}{|c|}{ 2010/11 } & \multicolumn{3}{|c|}{$2011 / 12$} & \multirow{2}{*}{$2012 / 13$} & \multicolumn{2}{|c|}{$2013 / 14 \quad 2014 / 15$} & $2015 / 16$ & \multirow[t]{2}{*}{$2016 / 17$} \\
\hline & & $\overline{E B S} / 10 / 88^{2}$ & EBS $/ 11 / 44^{3}$ & $\overline{\text { Est. }}$ & $\overline{E B S / 10 / 88^{2}}$ & EBS $/ 11 / 44^{3}$ & Proj. & & \multicolumn{3}{|c|}{ Projections } & \\
\hline & & -396 & -343 & -336 & -420 & -564 & -407 & -296 & -414 & -170 & 51 & 45 \\
\hline Trade balance & -951 & $-1,080$ & $-1,025$ & $-1,062$ & $-1,039$ & $-1,188$ & $-1,088$ & $-1,288$ & $-1,284$ & -853 & -507 & -461 \\
\hline Exports, f.o.b. & 779 & 775 & 860 & 951 & 817 & 950 & 1,103 & 1,242 & 1,282 & 1,568 & 1,902 & 1,997 \\
\hline Imports, f.o.b & $-1,730$ & $-1,855$ & $-1,885$ & $-2,013$ & $-1,856$ & $-2,138$ & $-2,191$ & $-2,530$ & $-2,566$ & $-2,421$ & $-2,409$ & $-2,458$ \\
\hline Services (net) & -417 & -41 & -459 & -495 & -43 & -524 & -490 & -504 & -488 & -483 & -491 & -497 \\
\hline Income (net) & 512 & 416 & 500 & 551 & 450 & 500 & 516 & 422 & 415 & 284 & 117 & 83 \\
\hline Of which: interest on public debt & -8 & -9 & -8 & -7 & -13 & -12 & -10 & -14 & -20 & -24 & -17 & -15 \\
\hline Transfers & 796 & 308 & 640 & 671 & 212 & 647 & 654 & 1,073 & 942 & 881 & 932 & 920 \\
\hline Official transfers & 652 & 307 & 479 & 501 & 210 & 474 & 480 & 899 & 767 & 705 & 746 & 723 \\
\hline Other transfers & 144 & 2 & 161 & 169 & 2 & 174 & 174 & 174 & 175 & 176 & 186 & 196 \\
\hline Capital and financial account & 25 & 206 & 88 & 15 & 234 & 270 & 253 & 444 & 499 & 264 & 175 & 165 \\
\hline Capital account & 84 & 123 & 164 & 55 & 189 & 268 & 157 & 171 & 93 & 56 & 86 & 79 \\
\hline Financial account & -58 & 83 & -75 & -40 & 44 & 2 & 96 & 274 & 406 & 208 & 89 & 85 \\
\hline Foreign direct & 109 & 64 & 133 & 120 & 66 & 138 & 200 & 332 & 533 & 332 & 173 & 180 \\
\hline Portfolio investment & 0 & 0 & 0 & 0 & 0 & 0 & 0 & 0 & 0 & 0 & 0 & 0 \\
\hline Other investment & -167 & 19 & -208 & -159 & -22 & -135 & -105 & -58 & -127 & -124 & -83 & -95 \\
\hline $\begin{array}{l}\text { Medium and long-term } \\
\text { Of which: }\end{array}$ & -167 & $\ldots$ & $\ldots$ & -159 & $\ldots$ & $\ldots$ & -105 & -58 & -127 & -124 & -83 & -95 \\
\hline Public sector (net) & 2 & $\ldots$ & $\ldots$ & -10 & $\ldots$ & $\ldots$ & 36 & 109 & 99 & 24 & 59 & 52 \\
\hline Disbursements & 35 & $\ldots$ & $\ldots$ & 18 & $\ldots$ & $\ldots$ & 60 & 139 & 134 & 56 & 87 & 79 \\
\hline Amortization & -32 & $\ldots$ & $\ldots$ & -28 & $\ldots$ & $\ldots$ & -24 & -30 & -35 & -32 & -28 & -27 \\
\hline Errors and omissions & -6 & 0 & 40 & 70 & 0 & 0 & 0 & 0 & 0 & 0 & 0 & 0 \\
\hline Overall balance & -40 & -190 & -254 & -250 & -186 & -294 & -154 & 148 & 85 & 94 & 226 & 210 \\
\hline Financing & 40 & 190 & 254 & 250 & 186 & 294 & 154 & -148 & -85 & -94 & -226 & -210 \\
\hline Memorandum items: & & & & & (Per & cent of GDP) & & & & & & \\
\hline Current account & -3.2 & -22.0 & -16.1 & -14.8 & -22.5 & -23.4 & -16.6 & -11.2 & -15.4 & -5.8 & 1.6 & 1.3 \\
\hline Trade balance & -50.0 & -60.0 & -48.2 & -46.9 & -55.7 & -49.3 & -44.4 & -48.6 & -47.6 & -28.9 & -15.5 & -13.5 \\
\hline Capital and financial account & 1.3 & $\ldots$ & $\ldots$ & 0.7 & $\ldots$ & $\ldots$ & 10.3 & 16.8 & 18.5 & 8.9 & 5.4 & 4.8 \\
\hline Overall balance & -2.1 & $\ldots$ & $\ldots$ & -11.0 & $\ldots$ & $\ldots$ & -6.3 & 5.6 & 3.1 & 3.2 & 6.9 & 6.1 \\
\hline Gross international reserves & & & & & & & & & & & & \\
\hline$(\text { US } \$ \text { millions })^{4}$ & 1,105 & 855 & 970 & 961 & 651 & 682 & 779 & 918 & 992 & 1,074 & 1,282 & 1,468 \\
\hline (months of imports) & 5.3 & 5.2 & 4.2 & 3.9 & 3.7 & 2.7 & 3.0 & 3.5 & 4.0 & 4.3 & 5.1 & 5.2 \\
\hline
\end{tabular}

Sources: Lesotho authorities and IMF staff estimates and projections.

${ }^{1}$ The fiscal year runs from April 1 to March 31.

${ }^{2}$ Values as in the original ECF request. Calendar year projections.

${ }^{3}$ Values as in the first ECF review. Calendar year projections.

${ }^{4}$ Including the SDR allocation in 2009. Assuming augmentation of access under the ECF program by 25 percent of quota. 
Table 6. Lesotho: Commercial Bank Performance Ratios, 2005-11

(As of end-December; percent)

\begin{tabular}{|c|c|c|c|c|c|c|c|}
\hline & 2005 & 2006 & 2007 & 2008 & 2009 & 2010 & 2011 \\
\hline \multicolumn{8}{|l|}{ I. Capital adequacy } \\
\hline a) Basel capital ratio & 22.0 & 19.0 & 14.0 & 13.7 & 13.8 & 15.3 & 15.3 \\
\hline \multicolumn{8}{|l|}{ b) Nonperforming loans net } \\
\hline \multicolumn{8}{|l|}{ c) Top 20 exposures to statutory } \\
\hline capital and reserves & 220 & 386 & 469 & 314 & 365 & 531 & 586 \\
\hline \multicolumn{8}{|l|}{ II. Asset quality } \\
\hline a) Loans to deposit ratio & 29 & 26 & 29 & 30 & 29 & 36 & 41 \\
\hline b) Earning assets to total assets & 93 & 90 & 92 & 93 & 91 & 92 & 92 \\
\hline c) Nonperforming loans to total assets & 2.0 & 2.0 & 2.0 & 4.0 & 0.7 & 3.0 & 2.4 \\
\hline d) Reserve for losses to total loans & 3.0 & 2.8 & 2.6 & 4.0 & 4.3 & 3.1 & 2.7 \\
\hline e) Reserve for losses to nonperforming loans & 167 & 132 & 193 & 196 & 136 & 98 & 110 \\
\hline \multicolumn{8}{|l|}{ III. Liquidity } \\
\hline a) Liquidity assets to total deposits & 120 & 101 & 95 & 101 & 102 & 100 & 93 \\
\hline b) Available reserves to total deposits & 8.0 & 3.5 & 3.4 & 1.9 & 3.5 & 3.6 & 2.5 \\
\hline c) Liquid assets to total assets & 77 & 78 & 76 & 76 & 75 & 73 & 68 \\
\hline d) Current assets to current liabilities & 86 & 105 & 106 & 106 & 107 & 108 & 109 \\
\hline \multicolumn{8}{|l|}{ IV. Profitability } \\
\hline a) Net income after tax to total income & 18 & 22 & 21 & 22 & 23 & $\ldots$ & $\ldots$ \\
\hline b) Retained income to total income & 16 & 22 & 16 & 32 & 23 & $\cdots$ & $\cdots$ \\
\hline c) Total expenses to total income & 81 & 70 & 71 & 69 & 68 & 65 & 72 \\
\hline d) Return on assets (ROA) & 2.0 & 0.3 & 1.7 & 2.7 & 2.8 & 2.7 & 2.8 \\
\hline e) Return on equity & 15.0 & 4.5 & 21.0 & 36.2 & 33.3 & 30.9 & 28.9 \\
\hline \multicolumn{8}{|l|}{ V. Solvency } \\
\hline a) Total debt ratio & 11 & 9 & 8 & 8 & 7 & 9 & 9 \\
\hline
\end{tabular}

Source: Central Bank of Lesotho. 
Table 7. Lesotho: Indicators of Capacity to Repay the IMF ${ }^{1}$

\begin{tabular}{|c|c|c|c|c|c|c|c|c|c|c|c|c|c|}
\hline & $2010 / 11$ & $2011 / 12$ & $2012 / 13$ & $2013 / 14$ & $2014 / 15$ & $2015 / 16$ & $2016 / 17$ & $2017 / 18$ & $2018 / 19$ & $2019 / 20$ & $2020 / 21$ & $2021 / 22$ & $2022 / 23$ \\
\hline & Act. & Proj. & Proj. & Proj. & Proj. & Proj. & Proj. & Proj. & Proj. & Proj. & Proj. & Proj. & Proj. \\
\hline \multicolumn{14}{|l|}{$\begin{array}{l}\text { IMF obligations based on existing credit } \\
\text { (Millions of SDRs) }\end{array}$} \\
\hline Principal & 4.2 & 0.4 & 2.8 & 1.8 & 1.1 & 0.8 & 2.1 & 2.7 & 2.7 & 2.7 & 1.9 & 0.6 & 0.0 \\
\hline Charges and interest & 0.0 & 0.0 & 0.0 & 0.0 & 0.0 & 0.0 & 0.0 & 0.0 & 0.0 & 0.0 & 0.0 & 0.0 & 0.0 \\
\hline \multicolumn{14}{|c|}{$\begin{array}{l}\text { IMF obligations based on existing and prospective credit } \\
\text { (Millions of SDRs) }\end{array}$} \\
\hline Principal & 4.9 & 0.4 & 2.8 & 1.8 & 1.1 & 0.8 & 2.1 & 4.7 & 9.0 & 10.1 & 9.3 & 8.0 & 5.4 \\
\hline Charges and interest & 0.0 & 0.0 & 0.0 & 0.0 & 0.1 & 0.1 & 0.1 & 0.1 & 0.1 & 0.1 & 0.1 & 0.0 & 0.0 \\
\hline \multicolumn{14}{|c|}{ Total obligations based on existing and prospective credit } \\
\hline Millions of SDRs & 4.9 & 0.4 & 2.8 & 1.8 & 1.2 & 0.9 & 2.3 & 4.8 & 9.1 & 10.2 & 9.4 & 8.0 & 5.4 \\
\hline Millions of US\$ & 7.5 & 0.6 & 4.5 & 2.8 & 1.9 & 1.4 & 3.6 & 7.6 & 14.3 & 16.1 & 14.8 & 12.7 & 7.0 \\
\hline Percent of exports of goods and services & 0.8 & 0.0 & 0.3 & 0.2 & 0.1 & 0.1 & 0.2 & 0.3 & 0.6 & 0.6 & 0.5 & 0.4 & 0.2 \\
\hline Percent of debt service ${ }^{2}$ & 20.4 & 1.7 & 10.2 & 5.1 & 3.4 & 3.2 & 8.3 & 19.2 & 33.9 & 35.6 & 30.5 & 24.1 & 12.8 \\
\hline Percent of GDP & 0.3 & 0.0 & 0.2 & 0.1 & 0.1 & 0.0 & 0.1 & 0.2 & 0.3 & 0.4 & 0.3 & 0.2 & 0.1 \\
\hline Percent of gross international reserves & 0.8 & 0.1 & 0.5 & 0.3 & 0.2 & 0.1 & 0.2 & 0.5 & 0.9 & 0.9 & 0.9 & 0.6 & 0.3 \\
\hline Percent of quota & 14.0 & 1.0 & 8.0 & 5.0 & 3.4 & 2.6 & 6.4 & 13.8 & 26.0 & 29.2 & 26.9 & 23.0 & 15.6 \\
\hline \multicolumn{14}{|l|}{ Outstanding IMF credit } \\
\hline Millions of SDRs & 16.2 & 21.5 & 50.2 & 54.1 & 53.1 & 52.3 & 50.1 & 45.4 & 36.5 & 26.3 & 17.0 & 9.0 & 3.6 \\
\hline Millions of US\$ & 25.4 & 34.3 & 79.7 & 85.8 & 84.0 & 82.6 & 79.1 & 71.7 & 57.5 & 41.6 & 25.2 & 12.9 & 4.6 \\
\hline Percent of exports of goods and services & 2.6 & 3.0 & 6.2 & 6.5 & 5.2 & 4.3 & 3.9 & 3.2 & 2.2 & 1.4 & 0.8 & 0.4 & 0.1 \\
\hline Percent of debt service ${ }^{2}$ & 69.0 & 102.4 & 181.7 & 156.0 & 151.2 & 184.8 & 185.8 & 181.4 & 135.8 & 92.0 & 51.8 & 24.6 & 8.4 \\
\hline Percent of GDP & 1.1 & 1.4 & 3.0 & 3.2 & 2.8 & 2.5 & 2.3 & 1.8 & 1.4 & 0.9 & 0.5 & 0.3 & 0.1 \\
\hline Percent of Gross International Reserves & 2.6 & 4.4 & 8.7 & 8.6 & 7.8 & 6.4 & 5.4 & 4.6 & 3.6 & 2.4 & 1.5 & 0.6 & 0.2 \\
\hline Percent of quota & 46.4 & 61.7 & 143.8 & 155.0 & 152.0 & 149.8 & 143.7 & 130.2 & 104.5 & 75.5 & 48.7 & 25.8 & 10.3 \\
\hline Net use of IMF credit (millions of SDRs) & 2.9 & 5.3 & 28.6 & 3.9 & -1.1 & -0.8 & -2.1 & -4.7 & -9.0 & -10.1 & -9.3 & -8.0 & -5.4 \\
\hline Disbursements & 7.8 & 5.7 & 31.4 & 5.7 & 0.0 & 0.0 & 0.0 & 0.0 & 0.0 & 0.0 & 0.0 & 0.0 & 0.0 \\
\hline Repayments & 4.9 & 0.4 & 2.8 & 1.8 & 1.1 & 0.8 & 2.1 & 4.7 & 9.0 & 10.1 & 9.3 & 8.0 & 5.4 \\
\hline \multicolumn{14}{|l|}{ Memorandum items: } \\
\hline Exports of goods and services (millions of US $\$$ ) & 984 & 1,138 & 1,279 & 1,320 & 1,608 & 1,941 & 2,036 & 2,213 & 2,565 & 2,873 & 3,168 & 3,522 & 3,898 \\
\hline Debt service (millions of US $\$)^{2}$ & 37 & 34 & 44 & 55 & 56 & 45 & 43 & 40 & 42 & 45 & 49 & 52 & 55 \\
\hline Nominal GDP (millions of US\$) & 2,267 & 2,453 & 2,648 & 2,695 & 2,951 & 3,268 & 3,415 & 3,900 & 4,176 & 4,473 & 4,791 & 5,131 & 5,495 \\
\hline Gross international reserves (millions of US\$) & 961 & 779 & 918 & 992 & 1,074 & 1,282 & 1,468 & 1,569 & 1,614 & 1,711 & 1,706 & 1,994 & 2,304 \\
\hline Quota (millions of SDRs) & 35 & 35 & 35 & 35 & 35 & 35 & 35 & 35 & 35 & 35 & 35 & 35 & 35 \\
\hline
\end{tabular}

Sources: IMF staff estimates and projections.

${ }^{1}$ ECF disbursements of SDR 7.78 million (22.3 percent of quota) June 9, 2010; six sucessive disbursements of SDR 5.68 million (16.3 percent of quota) upon completion of each of the six reviews, through May 2013; and an additional SDR 8.73 million (25 percent of quota) to the third disbursement from augmentation of access; in total SDR 50.61 million (145 percent of quota) during 2010-13.

${ }^{2}$ Total debt service includes IMF repayments. 
Table 8. Lesotho: Schedule of ECF Disbursements and Reviews, 2011-13 ${ }^{1}$

\begin{tabular}{|c|c|c|c|c|c|c|c|}
\hline \multirow{2}{*}{ Date } & \multirow{2}{*}{ Conditions } & \multicolumn{2}{|c|}{ Original ECF disbursement } & \multicolumn{2}{|c|}{ Proposed ECF augmentation } & \multicolumn{2}{|c|}{ Total disbursement } \\
\hline & & Millions of SDRs & Percent of quota ${ }^{2}$ & Millions of SDRs & Percent of quota ${ }^{2}$ & Millions of SDRs & Percent of quota $^{2}$ \\
\hline 9-Jun-10 & Executive Board approval & 7.800 & 22.3 & - & - & 7.800 & 22.3 \\
\hline 4-Apr-11 & $\begin{array}{l}\text { Completion of the first review on a lapse-of time } \\
\text { basis, based on observance of performance criteria } \\
\text { through September } 30,2010\end{array}$ & 5.680 & 16.3 & - & - & 5.680 & 16.3 \\
\hline 16-Apr-12 & $\begin{array}{l}\text { Completion of combined second and third reviews, } \\
\text { based on observance of performance criteria through } \\
\text { end-March } 31,2011 \text {, and end-September } 30,2011\end{array}$ & 11.360 & 32.6 & 8.725 & 25.0 & 20.085 & 57.6 \\
\hline 20-Aug-12 & $\begin{array}{l}\text { Completion of fourth review, based on observance of } \\
\text { performance criteria through March } 31,2012\end{array}$ & 5.680 & 16.3 & - & - & 5.680 & 16.3 \\
\hline 20-Feb-13 & $\begin{array}{l}\text { Completion of fifth review, based on observance of } \\
\text { performance criteria through September 30, } 2012\end{array}$ & 5.680 & 16.3 & - & - & 5.680 & 16.3 \\
\hline 20-May-13 & $\begin{array}{l}\text { Completion of sixth review, based on observance of } \\
\text { performance criteria through March } 31,2013\end{array}$ & 5.680 & 16.3 & - & - & 5.680 & 16.3 \\
\hline Total & & 41.880 & 120.0 & 8.725 & 25.0 & 50.605 & 145.0 \\
\hline
\end{tabular}

Source: IMF staff estimates

1 Disbursements are expected to take place shortly after Board meeting

${ }^{2}$ Lesotho's quota is SDR 34.9 million. 
Table 9: Lesotho: Millennium Development Goals

\begin{tabular}{|c|c|c|c|c|c|}
\hline & 1990 & 1995 & 2000 & 2005 & 2010 \\
\hline \multicolumn{6}{|l|}{ Goal 1: Eradicate extreme poverty and hunger } \\
\hline Employment to population ratio, $15+$, total $(\%)$ & 48 & 50 & 59 & 55 & 54 \\
\hline Employment to population ratio, ages $15-24$, total (\%) & 39 & 40 & 47 & 42 & 41 \\
\hline GDP per person employed (constant 1990 PPP \$) & .. & .. & .. & .. & .. \\
\hline Income share held by lowest $20 \%$ & .. & 1 & .. & 3 & .. \\
\hline Malnutrition prevalence, weight for age ( $\%$ of children under 5 ) & 14 & .. & 15 & 17 & .. \\
\hline Poverty gap at $\$ 1.25$ a day (PPP) (\%) & .. & 26 & .. & 21 & .. \\
\hline Poverty headcount ratio at $\$ 1.25$ a day (PPP) (\% of population) &.. & 46 & .. & 43 & .. \\
\hline Vulnerable employment, total (\% of total employment) &.. & .. & .. & .. & .. \\
\hline \multicolumn{6}{|l|}{ Goal 2: Achieve universal primary education } \\
\hline Literacy rate, youth female ( $\%$ of females ages $15-24)$ &.. & .. & 97 & .. & 98 \\
\hline Literacy rate, youth male (\% of males ages $15-24$ ) &.. & .. & 85 & .. & 86 \\
\hline Persistence to last grade of primary, total ( $\%$ of cohort) &.. & .. & 55 & 63 & .. \\
\hline Primary completion rate, total ( $\%$ of relevant age group) & 58 & 64 & 60 & 60 & 70 \\
\hline Total enrollment, primary (\% net) & 71 & 68 & 78 & 75 & 73 \\
\hline \multicolumn{6}{|l|}{ Goal 3: Promote gender equality and empower women } \\
\hline Proportion of seats held by women in national parliaments (\%) & .. & 5 & 4 & 12 & 24 \\
\hline Ratio of female to male primary enrollment (\%) & 122 & 112 & 104 & 100 & 98 \\
\hline Ratio of female to male secondary enrollment (\%) & 146 & 142 & 132 & 127 & 138 \\
\hline Ratio of female to male tertiary enrollment (\%) & 125 & 112 & 162 & 134 & .. \\
\hline \multicolumn{6}{|l|}{ Goal 4: Reduce child mortality } \\
\hline Immunization, measles ( $\%$ of children ages $12-23$ months) & 80 & 83 & 74 & 85 & 85 \\
\hline Mortality rate, infant (per 1,000 live births) & 72 & 77 & 88 & 83 & 65 \\
\hline Mortality rate, under-5 (per 1,000 ) & 89 & 99 & 127 & 121 & 85 \\
\hline \multicolumn{6}{|l|}{ Goal 5: Improve maternal health } \\
\hline Adolescent fertility rate (births per 1,000 women ages 15-19) & .. & 94 & 91 & 80 & 68 \\
\hline Births attended by skilled health staff (\% of total) & .. & 50 & 60 & 55 & 62 \\
\hline Contraceptive prevalence (\% of women ages $15-49$ ) & 23 & 29 & 30 & 37 & 47 \\
\hline Maternal mortality ratio (modeled estimate, per 100,000 live births) & 370 & 340 & 470 & 570 & 530 \\
\hline Pregnant women receiving prenatal care (\%) & .. & 88 & 85 & 90 & 92 \\
\hline Unmet need for contraception ( $\%$ of married women ages $15-49$ ) & .. &.. &.. & 31 & .. \\
\hline \multicolumn{6}{|l|}{ Goal 6: Combat HIVIAIDS, malaria, and other diseases } \\
\hline Condom use, population ages $15-24$, female (\% of females ages $15-24)$ & .. & .. &.. & 26 & .. \\
\hline Condom use, population ages $15-24$, male ( $\%$ of males ages $15-24)$ & .. & .. &.. & 44 & .. \\
\hline Incidence of tuberculosis (per 100,000 people) & 184 & 323 & 553 & 639 & 633 \\
\hline Prevalence of HIV, female (\% ages $15-24)$ &.. & .. &.. & .. & 14.2 \\
\hline Prevalence of HIV, male (\% ages $15-24)$ &.. &.. &.. & .. & 5.4 \\
\hline Prevalence of HIV, total (\% of population ages $15-49$ ) & 0.8 & 14.3 & 24.5 & 23.6 & 23.6 \\
\hline Tuberculosis case detection rate (\%, all forms) & 84 & 89 & 90 & 82 & 85 \\
\hline \multicolumn{6}{|l|}{ Goal 7: Ensure environmental sustainability } \\
\hline CO2 emissions (kg per PPP \$ of GDP) & .. & .. & .. & .. & .. \\
\hline $\mathrm{CO} 2$ emissions (metric tons per capita) & .. & .. & .. & .. & .. \\
\hline Forest area (\% of land area) & 1.3 & .. & 1.4 & 1.4 & 1.4 \\
\hline Improved sanitation facilities (\% of population with access) & 32 & 31 & 29 & 28 & 29 \\
\hline Improved water source (\% of population with access) & 61 & 64 & 74 & 83 & 85 \\
\hline Marine protected areas ( $\%$ of territorial waters) & .. & .. &.. & .. & .. \\
\hline Net ODA received per capita (current US\$) & 85 & 63 & 19 & 33 & 57 \\
\hline \multicolumn{6}{|l|}{ Goal 8: Develop a global partnership for development } \\
\hline Debt service (PPG and IMF only, \% of exports, excl. workers' remittances) & 4 & 6 & 11 & 6 & 2 \\
\hline Internet users (per 100 people) & 0 & 0 & 0.2 & 2.6 & 3.9 \\
\hline Mobile cellular subscriptions (per 100 people) & 0 & 0 & 1 & 12 & 32 \\
\hline Telephone lines (per 100 people) & 1 & 1 & 1 & 2 & 2 \\
\hline Fertility rate, total (births per woman) & 5 & 5 & 4 & 4 & 3 \\
\hline \multicolumn{6}{|l|}{ Other } \\
\hline GNI per capita, Atlas method (current US\$) & 540 & 640 & 530 & 840 & 1,040 \\
\hline GNI, Atlas method (current US\$) (billions) & 0.9 & 1.1 & 1 & 1.7 & 2.2 \\
\hline Gross capital formation (\% of GDP) & 56.1 & 76.4 & 44.2 & 25.1 & 33.7 \\
\hline Life expectancy at birth, total (years) & 59 & 57 & 48 & 44 & 47 \\
\hline Literacy rate, adult total ( $\%$ of people ages 15 and above) & .. & .. & 86 & .. & 90 \\
\hline Population, total (billions) & 0 & $\ddot{0}$ & 0 & 0 & 0 \\
\hline Trade (\% of GDP) & 141.3 & 151.6 & 137.6 & 156 & 163 \\
\hline
\end{tabular}

Source: World Development Indicators 


\section{Appendix I: Kingdom of Lesotho: Letter of Intent}

March 23, 2012

Ms. Christine Lagarde

Managing Director

International Monetary Fund

Washington, D.C. 20431

United States of America

Dear Ms. Lagarde,

This letter and the attached Memorandum of Economic and Financial Policies (MEFP) update and supplement my communication of February 24, 2011; describe performance under the government's economic program, and outline the Government's economic policies and program for the remainder of 2011/12 and 2012/13.

Lesotho was hit by successive shocks that had a devastating effect on infrastructure, people and Government fiscal operations. A sharp decline in SACU revenue of more than 50 percent in 2010 was followed by devastating floods in early 2011, whose impact is estimated at about M700 million (Seven Hundred Million Maloti) and has affected about 600,000 (Six Hundred Thousand) people or 58 percent of the population. In response, the Government embarked on a program of rehabilitation and fiscal consolidation aimed at rebuilding our reserves from the current low level of three months of import cover to at least 5 months of coverage over the medium term. In this regard, we are seeking external support, including additional financial support from the IMF. Notwithstanding these severe shocks, we have been successfully implementing economic and financial policy reforms which the Fund is supporting through a three-year Extended Credit Facility (ECF) arrangement.

All performance criteria through end-March 2011 and end-September were met. Structural reforms have progressed albeit with some delays. Five out of eight structural benchmarks (SBs) due under the second and third reviews were implemented while the other three have not yet been implemented. The new Financial Institutions Act has been passed by both Houses of Parliament and is now in force, while the audit of domestic arrears (a benchmark for March 2011) has been delayed and is now expected to be completed by March 2012. This is due to the problems with the Integrated Financial Management Information System (see Table 2 of the attached MEFP).

Regarding the National Strategic Development Plan (NSDP), I am pleased to inform you that Cabinet has approved the NSDP subject to final editing and inclusion of a Foreword by The Right Honourable The Prime Minister prior to printing. The NSDP describes the 
Government's strategy for high and sustainable growth, employment creation and poverty reduction and covers the period 2012/13-2016/17. We expect the NSDP to be used as a basis for the Joint Staff Advisory Note (JSAN) jointly prepared by the staffs of the World Bank and the IMF.

The NSDP is an outcome of the joint effort by all Basotho, the Government and Development Partners who participated through working groups and public consultations. On behalf of the Government of Lesotho, I would like to extend to you our gratitude for the support of the Fund in the NSDP preparation process. We look forward to working with the IMF in ensuring effective and full implementation of the NSDP. The NSDP will also be posted on our website, http://www.gov.ls/. We have no objection to the publication of the NSDP on the IMF website as well.

In view of the foregoing, the Government of Lesotho requests (i) the completion of the second and third reviews, (ii) the augmentation of access to resources under the ECF arrangement by an amount of SDR 8.73 million (equivalent to 25 percent of quota), and (iii) disbursement of the third and fourth tranche under the arrangement, equivalent to SDR 20.085 million (57.6 percent of quota), which includes the proposed augmented amount. Performance criteria and structural benchmarks for 2011-12 are included in Tables 1 and 3 of the MEFP.

We continue to believe that the policies set forth in the attached MEFP are adequate to achieve the objectives of the program, notwithstanding the new macroeconomic challenges we face. The Government however, stands ready to take any further measures that may become necessary to achieve our policy objectives. The government of Lesotho will consult with the IMF - at its own initiative or whenever the Managing Director of the IMF requests such a consultation - on the adoption of these measures and in advance of any revisions to the policies contained in the MEFP. These consultations will be in accordance with the IMF's policies on such consultations.

The Government will provide such information as the IMF may request in connection with the progress made in implementing the economic and financial policies, and achieving the objectives of the program. The Government authorizes the IMF to publish this letter, the attached MEFP and TMU, and the related Staff Report, including placement of these documents on the IMF website.

Yours sincerely, $/ \mathrm{s} /$

Hon. Timothy T. Thahane, Minister of Finance and Development Planning

Attachments 
Attachment 1: Kingdom of Lesotho: Memorandum of Economic and Financial Policies for 2011/12-2012/13

\section{INTRODUCTION AND BACKGROUND}

1. The Government of Lesotho firmly reiterates its commitment to the mediumterm economic program supported by the ECF arrangement. As laid out in the MEFP dated February 24, 2011, our program aims at restoring fiscal and external sustainability, while limiting the adverse impact of fiscal consolidation on the poor and vulnerable groups; mitigating the impact of external shocks and achieving broad-based growth for sustained poverty reduction; and strengthening the financial sector and the business climate.

2. This memorandum:

- Describes the recent economic developments, including the impact of the floods on the economy in late 2010 and early 2011.

- $\quad$ Reviews macroeconomic and financial performance under the ECF-supported program through end-September 2011.

- $\quad$ Updates the MEFP of February 24, 2011 and describes macroeconomic and financial policies for the remainder of 2011/12 and 2012/13.

\section{RECENT ECONOMIC DEVELOPMENTS}

\section{Despite the significant drop in Southern African Customs Union (SACU)} revenues in 2010/11, we have made remarkable progress in economic reforms and achieved large fiscal consolidation. The fiscal deficit for 2010/11 was reduced to 5 percent of GDP ${ }^{1}$ reflecting strong revenue performance including windfall SACU revenues ${ }^{2}$, a large dividends payment from the Central Bank of Lesotho (CBL), and efforts to contain spending. The core SACU fiscal balance ${ }^{3}$ improved significantly (by some 15 percent of GDP) from a deficit of 20 percent of GDP in 2009/10 to a deficit of 5 $\frac{1}{2}$ percent of GDP in 2010/11. This

\footnotetext{
${ }^{1}$ This compared with original projection under the program of 19 percent of GDP, and budgeted deficit of 12.3 percent of GDP.

${ }^{2}$ The SACU revenues received in 2010/11 were significantly larger than originally projected.

${ }^{3}$ SACU revenues are separated into core component (equivalent to 15 percent of GDP being the lowest annual receipt in the last two decades) and noncore component (the rest). The core fiscal balance is defined as the fiscal balance excluding the noncore component of SACU revenues and the foreign project loans.
} 
Bredaachievement in fiscal adjustment also helped to limit external imbalances, despite rising international commodity prices. The level of reserves stood at $\$ 961$ million at the end$2010 / 11$, much higher than the original program projection of $\$ 855$ million.

4. The floods in early 2011 caused widespread damages and loss of lives. According to the 2011 Post Disaster Needs assessment (conducted jointly with Lesotho's development partners), 250,000 people (13.6 percent of the total population) were affected by the floods. With heavy losses of crops and livestock, significant food imports were required. Infrastructure damages (roads, water and sanitation) have also been significant. Under these circumstances, we made budgetary provision in 2011/12 (2.2 percent of GDP) to cover some of the costs of recovery and rehabilitation, some of which programs will carry over into 2012/13.

5. A combination of the global food and oil price shock and the floods has taken a heavy toll on our economy, requiring additional external assistance. Preliminary estimates put the financial requirements for post-flood recovery and reconstruction at M649 million (about $3 \frac{1}{2}$ percent of GDP) for both public and private sectors. The reconstruction, together with the surge in international commodity prices, also increased our import costs by about 4 percent of GDP compared to what was projected when we embarked on the ECFsupported program. Thus far, our development partners have pledged US\$2.8 million, of which will be disbursed in 2012/13. We have been seeking further external support, including the augmentation of the ECF arrangement.

6. Lesotho's medium-term macroeconomic prospects remain challenging despite a modest growth recovery. Economic growth is expected to improve, with the expansion of mining activities and the implementation of large infrastructure projects (including the Metolong dam). At the same time, however, the current account deficit is expected to increase in 2011/12 resulting from increased imports which will lead to further pressures on international reserves. In the short-term, our main challenge is to sustain our fiscal consolidation efforts while meeting our urgent reconstruction and development needs. Looking forward, the uncertain global economic outlook is also a source of concern.

\section{Performance Under the Program}

7. Overall performance under the ECF-supported program has been strong. All quantitative performance criteria for end-March 2011 and end-September 2011 were met. The indicative target for the floor on social spending was also met (Table 1).

\section{Structural reforms are also progressing, albeit with delays in some areas}

(Table 2). In the financial sector, the implementation of the Financial Institutions Act will pave the way for further strengthening of the supervisory and regulatory framework for banks and non-bank financial institutions. A plan for capacity building in line ministries to 
prepare medium-term expenditure frameworks (MTEF) has been produced; and work has begun to prepare regulations for implementation of the National Lease Financing proposal, consistent with the new Financial Institutions Act (FIA). The review of the Cooperatives Societies Act and the launch of a partial credit guarantee scheme have been completed, albeit with some delays. On the audit of domestic arrears, however, progress has been made following the establishment of a task team in December 2011. On the front office revenue receipting system, to ensure smooth introduction, the work has begun with three pilot ministries and one sub-accountancy. The Industrial Licensing Bill has been drafted and submitted to the Attorney General for approval.

\section{Macroeconomic Policies under the Program}

9. We remain committed to a fiscal consolidation program aimed at achieving a sustainable fiscal and external position over the medium term while addressing our development and social needs. In support of our exchange rate peg, significant fiscal consolidation is called for to restore macroeconomic stability and preserve an adequate level of international reserves. We continue to make efforts in cutting non-productive expenditures while creating fiscal space for critical infrastructure projects and for support to vulnerable groups. The current account imbalance is expected to narrow over the medium-term, in line with fiscal consolidation, supported by strong performance in the mining sector. We expect that the implementation of our medium-term policy framework will restore fiscal and external sustainability.

10. Over the medium-term, to achieve our objective of sustained economic growth as the most effective route for poverty reduction, we will also make further efforts in increasing Lesotho's resilience to shocks and promoting private sector development. To prepare for future shocks, we intend to gradually rebuild the international reserves buffer, raising international reserves toward the equivalent of five months of imports. A public debt management strategy will be formulated to support fiscal and debt sustainability. To achieve sustained growth and increase employment, we will also promote private sector development through enhancing access to credit and improving business climate. In this regard, the government has committed to implementing a set of comprehensive reforms under the National Strategic Development Plan (NSDP).

\section{A. Macroeconomic Policies for the remainder of 2011/12}

11. We will make further progress in fiscal consolidation while securing floodrelated capital outlays. Despite the high costs of rehabilitation of flood-damaged infrastructure (2.2 percent of GDP), included in the 2011/12 budget, we have maintained tight limits on recurrent expenditure. As a result, the fiscal deficit is projected at $101 / 2$ percent of GDP in 2011/12, even tighter than the adjustment program agreed to during the first review, and compatible with restoring macroeconomic stability. To enhance the efficiency of 
revenue administration, LRA has embarked on broadening the tax base by expanding the taxpayer's registration. In the event that fiscal revenue is better than expected, the available resources will be used to build up our deposits at the CBL.

\section{Seeking external financing}

12. High international commodity prices and the floods have created large financing needs, for which we are seeking external support, including an augmentation of the ECF arrangement in an amount equivalent to SDR 8.73 million (25 percent of quota). High international fuel and food prices have added substantially to import costs, and the loss of crops caused by the flooding has necessitated significant reconstruction and emergency food imports (estimated at about US\$60 million). To seek donor support, we presented our case at an international disaster management conference in Geneva in May 2011. Operational guidelines for the Disaster Risks Reduction Fund were prepared in November 2011, for which the total of US\$2.8 million has been pledged by UN Central Emergency Response, UNDP, Ireland, People's Republic of China, and OCHA. The fund will be operational in 2012/13.

13. To ensure debt sustainability, the government will continue to seek external financing through grants and concessional loans and save any unplanned inflows. As agreed with the IMF, non-concessional financing will be limited to the European Investment Bank loan for the Metolong Dam Project. In addition, we are assessing options for the medium-term financing of the second phase of the Lesotho Highlands Water Project, which, as an enclave project, is unlikely to be available on concessional terms.

\section{B. Macroeconomic Policies for 2012/13 and beyond}

14. To achieve our medium-term objective of rebuilding international reserves in support of the peg, we will maintain our adjustment efforts. While SACU revenues are projected to increase, we will target a deficit limit in the core SACU fiscal balance of 8.6 percent of GDP for 2012/13. Accordingly, we intend to step up fiscal consolidation by (i) freezing new positions (excluding those related to education, police and defense), (ii) keeping civil servant wages constant in real terms, (iii) reducing non-priority outlays through stricter expenditure control, and (iv) establishing strict guidelines to limit contingency spending to emergencies. We remain committed to further containing recurrent expenditures, especially spending on goods and services, while protecting spending for vulnerable groups and some priority infrastructure and ensuring efficiency in public service delivery. On the revenue side, we will undertake a full restructuring of the Lesotho Revenue Authority (LRA) in 2012/13, including the operationalization of a full-service Large Tax Payer Unit by end-March 2013, that will cater to medium-to-large taxpayers. The LRA continues to implement core business processes and enforcement strategies designed to strengthen revenue collection, by improving recovery of unpaid taxes, strengthening compliance and service delivery. In case 
SACU revenues are higher than anticipated, the available resources will be used to build up deposits at the CBL. If SACU revenues are projected to decline over the medium-term, we will undertake offsetting measures to reduce spending on goods and services.

\section{Structural Reforms}

\section{Public Financial Management}

15. PFM reforms will continue, with the support of our development partners, to improve the efficiency of our budget process. Steady progress has been made, but challenges remain, including problems with the functionality of IFMIS. Cash management will be further strengthened through the establishment of the Cash Management Unit, and a comprehensive inventory of all government accounts, including those at commercial banks, will be undertaken by December 2012 (structural benchmark). By March 2012, we will start implementing a front office revenue receipting system in three ministries and one subaccountancy, capturing all non-tax revenues from these pilot ministries in the IFMIS (structural benchmark). Activities will also focus on further improvements in the functionality of IFMIS, resolving interface and other IFMIS problems, and increasing staff training in the use of the system.

\section{With a view to strengthening expenditure management, we will step up our} efforts to clear domestic arrears with assistance from our development partners.

Drawing upon the recommendations of an IMF technical assistance team, we have formulated a time-bound audit plan with a view to completing an audit of domestic arrears by March 2012 (structural benchmark). We have given instructions to line ministries to verify the data in the system each month and to report any arrears on monthly basis. We intend to modify a legal framework for allowing the recognition of electronic documents. This is critical for expediting the government payments and the reconciliation of treasury and the central bank accounts. We are also committed to preventing the emergence of new domestic arrears in the future by implementing processes that ensure timely payments to suppliers.

\section{Supporting financial sector development}

\section{We have strengthened our legal framework to promote financial sector}

development. Following the enactment of the new FIA in February 2012, a time-bound action plan for its effective implementation has been prepared, and work is also underway to prepare regulations for nonbank financial institutions by mid-2012. The FIA empowers the CBL to deal effectively with unlawful business practices, including Ponzi schemes, and to regulate and supervise nonbank financial institutions (money lenders, foreign exchange bureau, and microfinance). In addition, by mid-2012, we plan on advancing the work to modernize Postbank (e.g., mobile banking) and expand its services to the rural areas, 
introducing the new Insurance law, and formulating the new pension and retirement fund law.

\section{Improving productivity and the investment climate}

18. We will continue to work closely with our development partners to implement reforms that will facilitate private sector development and economic diversification. A number of reforms aimed at improving the business environment have been implemented, and several are underway. The Partial Credit Guarantee Scheme was launched in August 2011 , with a view to allowing greater access to credit by small and medium enterprises. The Companies Act 1967 has been reviewed and the new Companies Act 2011 will come into operation by June 2012; the new Act introduces a short, simple and cost effective mechanism for incorporation and registration of companies. The Trading Enterprise Regulations have been amended, and published in December 2011, the amendment reduces the time required to start a business by at least 14 days and while the Law used to require every business to operate from business premises, the Regulations now allow some businesses (i.e. consultancies) to operate from residences. Among the next steps, we intend to submit the Industrial Licensing Bill to Parliament by end-September 2012 (structural benchmarks), which would streamline the process of granting manufacturing/industrial licenses in a transparent manner.

\section{Poverty reduction strategy document}

\section{A comprehensive five-year National Strategic Development Plan (NSDP)} (2012/13-2016/17) has been finalized with the support of our development partners, and was submitted on March 23, 2012 to the IMF and the World Bank as a Poverty Reduction Strategy document. The NSDP was prepared in a fully participatory manner through comprehensive stakeholder consultation. The Government has set the objective of enabling the private sector to create at least 50,000 sustainable jobs by the end of the Plan period. To this end, we intend to increase private sector participation by significantly reducing barriers to private investment and private sector development. Those barriers are: (i) uncompetitive business environment, (ii) relatively poor infrastructure for trade facilitation that also crowds out private investment, (iii) low productivity as a result of limited quality technical skills, poor health mainly as a result of HIV and AIDS and low entrepreneurship capacity and quality management and (iv) limited institutional capacity for regulatory and policy reforms, investment and trade promotion and weak private sector organizations. To address these problems, the NSDP sets its primary objectives as: (i) accelerating shared and employment creating economic growth, (ii) developing infrastructure (Minimum Infrastructure Platform), (iii) enhancing the skills base and foundation for innovation, (iv) reversing environmental degradation and adapt to climate change, (v) improving health, 
combat HIV and AIDS and reduce social vulnerability, and (vi) building effective institutions and promote democratic governance.

20. Under the NSDP, we are forecasting at real average GDP growth of 1.5 percent under the low growth scenario, 5.8 percent under the moderate scenario and 6.7 percent under the Plan scenario. For the purpose of the program and the budget, we maintain the conservative assumption of average growth of 4.5 percent during 2012/13 and 2016/17.

Real GDP Growth Forecast under the Budget and the ECF Arrangement

\begin{tabular}{lccccccc}
\hline & $2010 / 11$ & $2011 / 12$ & $2012 / 13$ & $2013 / 14$ & $2014 / 15$ & $2015 / 16$ & $2016 / 17$ \\
\hline Real GDP Growth (annual change) & 5.7 & 4.2 & 5.2 & 2.2 & 5.9 & 6.3 & 3.1 \\
\hline
\end{tabular}

\section{Program Issues}

\section{Safeguards assessment}

21. We have made significant progress in implementing the recommendations of the 2010 safeguards assessment of the CBL. The assessment concluded that key elements of the safeguards framework had been strengthened since the 2003 assessment, but also that risks remained, in particular in the external audit mechanism. To address this, we appointed Deloitte \& Touche as sole auditor for the CBL's annual accounts for the year ended December 31, 2010. The audit was completed within the statutory deadline, and the audited financial statements and audit opinion were posted on the bank's external website in April 2011. The CBL has also introduced internal audits of monetary data to be submitted for program monitoring purposes. We acknowledge that, should the access under the current ECF arrangement be augmented, an updated safeguards assessment would need to be completed. Deloitte \& Touche (South Africa) has been reappointed to conduct the 2011 external audit jointly with a local firm. Both firms will sign the audit opinion. The 2011 audit is underway and should be completed by end-March 2012.

\section{Program monitoring}

22. Completion of the fourth, fifth and sixth reviews of the arrangement, by August 20, 2012 and February 20, 2013, and May 20, 2013, respectively, will be based on the observance of quantitative performance criteria through end-March 2012, endSeptember 2012, and end-March 2013, respectively (Table 1). The targets for end-June and end-December 2012 will be indicative. The definitions of the variables monitored as quantitative performance criteria are provided in the Technical Memorandum of Understanding (TMU).

23. The Government is committed to ensuring that the program remains on track and will continue to monitor implementation. 
Table 1. Lesotho: Quantitative Performance Criteria, Benchmarks, and Indicative Targets, March 2011 - September 2012

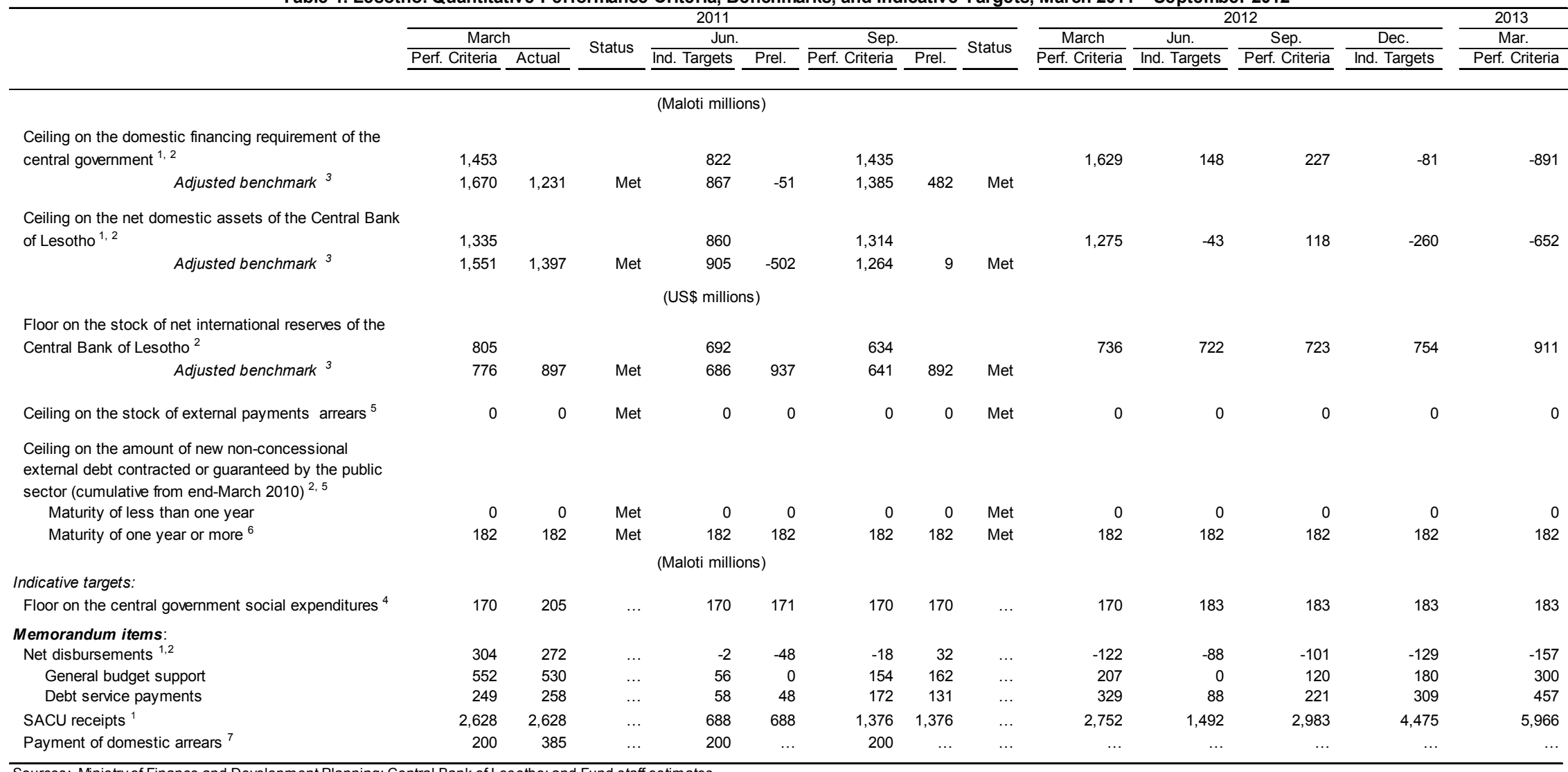

Sources: Ministry of Finance and Development Planning; Central Bank of Lesotho; and Fund staff estimates

${ }^{1}$ Values are cumulative from April 1st (beginning of the fiscal year)

${ }^{2}$ Definitions and program adjusters are specified in the TMU.

${ }^{3}$ Adjusted for lower budget support

${ }^{4}$ Includes spending on school feeding program, old age pension and HIVIAIDS

${ }^{5}$ Continuous performance criteria

${ }^{6} \mathrm{New}$ nonconcessional borrowing is limited to financing the Metolong dam

${ }^{7}$ The ceiling on gross cumulative payments of domestic arrears will no longer be monitored as an indicative target. 
Table 2. Lesotho Structural Benchmarks for FY2010/11

\begin{tabular}{|c|c|c|c|}
\hline Structural Benchmarks & Test Date & Status & Comments \\
\hline \multicolumn{4}{|l|}{ I. Public Financial Management } \\
\hline $\begin{array}{l}\text { Complete an audit of domestic arrears and prepare a } \\
\text { time bound plan for elimination }\end{array}$ & End-March 2011 & Not met & $\begin{array}{l}\text { Preliminary work started by internal auditors. } \\
\text { The FAD PFM TA mission provided guidance } \\
\text { on an auditing framework and regulatory } \\
\text { arrangements for arrears management }\end{array}$ \\
\hline $\begin{array}{l}\text { Prepare a time bound plan for capacity building in line } \\
\text { ministries to strengthen preparation of MTEF by all } \\
\text { ministries }\end{array}$ & End-June 2011 & Met & \\
\hline $\begin{array}{l}\text { Implement the front office revenue receipting system and } \\
\text { ensure that all revenues are captured in the IFMIS }\end{array}$ & $\begin{array}{l}\text { End-September } \\
2011\end{array}$ & Not met & $\begin{array}{l}\text { Delayed due to the problem with IFMIS. To } \\
\text { ensure smooth introduction, work has begun } \\
\text { with three pilot ministries. }\end{array}$ \\
\hline \multicolumn{4}{|l|}{ II. Financial Sector Regulation } \\
\hline $\begin{array}{l}\text { Submit to Parliament the new Financial Institutions Bill, } \\
\text { which incorporates amendments to deal with supervision } \\
\text { of NBFls by the CBL, and unlawful business practices, } \\
\text { including Ponzi schemes }\end{array}$ & End-March 2011 & Met & \\
\hline $\begin{array}{l}\text { Submit to Cabinet a review of the Cooperatives } \\
\text { Societies Act with a view to ensuring that all financial } \\
\text { institutions that accept deposits from the public comply } \\
\text { with and are registered under the FIA }\end{array}$ & End-March 2011 & Met with delay & $\begin{array}{l}\text { Submitted to Cabinet for policy clearance in } \\
\text { May } 2011\end{array}$ \\
\hline $\begin{array}{l}\text { Launch a Partial Credit Guarantee Scheme, aimed at } \\
\text { reducing the risks for banks to lend to small and medium- } \\
\text { sized enterprises }\end{array}$ & End-March 2011 & Met with delay & $\begin{array}{l}\text { Delayed to allow for consultation with } \\
\text { stakeholders, including banks, on modalities } \\
\text { for implementation. It was launched in August } \\
2011\end{array}$ \\
\hline $\begin{array}{l}\text { Submit to Cabinet the National Leasing Finance } \\
\text { proposal, aimed at creating a legal environment } \\
\text { conducive to leasing, by supplementing the } 1974 \text { Hire } \\
\text { Purchase Act. }\end{array}$ & End-June 2011 & Met & $\begin{array}{l}\text { There was a change in concept/modality. The } \\
\text { new FIA makes provision for leasing finance. } \\
\text { Work began in May } 2011 \text { to prepare the } \\
\text { necessary regulations. }\end{array}$ \\
\hline \multicolumn{4}{|l|}{ III. Structural Reforms } \\
\hline $\begin{array}{l}\text { Submit to Parliament the Industrial Licensing Bill, which } \\
\text { will improve the process of licensing industrial } \\
\text { enterprises }\end{array}$ & End-March 2011 & Not met & $\begin{array}{l}\text { Delayed due to need for clarifications by the } \\
\text { Attorney General's Department. }\end{array}$ \\
\hline
\end{tabular}


Table 3. Proposed Structural Benchmarks through December 2012

\begin{tabular}{|c|c|c|}
\hline Benchmarks & Test date & Macroeconomic rationale \\
\hline \multicolumn{3}{|l|}{ I. Public Financial Management } \\
\hline $\begin{array}{l}\text { Implement the front office revenue receipting system in } 3 \text { pilot } \\
\text { ministries and } 1 \text { sub accountancy }{ }^{1}\end{array}$ & End-March 2012 & $\begin{array}{l}\text { Strengthen revenue tracking and support } \\
\text { medium-term fiscal consolidation }\end{array}$ \\
\hline $\begin{array}{l}\text { Complete an audit of domestic arrears and prepare a time bound } \\
\text { plan for elimination }{ }^{2}\end{array}$ & End-March 2012 & $\begin{array}{l}\text { Support expenditure control and medium-term } \\
\text { fiscal consolidation }\end{array}$ \\
\hline $\begin{array}{l}\text { Undertake a comprehensive inventory of Government accounts, } \\
\text { including those in commercial banks. }\end{array}$ & End-June 2012 & $\begin{array}{l}\text { Support expenditure efficiency and medium- } \\
\text { term fiscal consolidation }\end{array}$ \\
\hline $\begin{array}{l}\text { Reconcile key Treasury (Revenue and Expenditure) Accounts on a } \\
\text { monthly basis and produce a monthly monitoring report showing the } \\
\text { status of reconciliation of all bank accounts. }\end{array}$ & End-September 2012 & $\begin{array}{l}\text { Support expenditure efficiency and medium- } \\
\text { term fiscal consolidation }\end{array}$ \\
\hline Establish a Cash Management Unit in the Treasury. & End-December 2012 & $\begin{array}{l}\text { Support expenditure efficiency and medium- } \\
\text { term fiscal consolidation }\end{array}$ \\
\hline \multicolumn{3}{|l|}{ II. Other Structural Reforms } \\
\hline $\begin{array}{l}\text { Submit to Parliament the Industrial Licensing Bill, which will improve } \\
\text { the process of licensing industrial enterprises }{ }^{2}\end{array}$ & End-September 2012 & $\begin{array}{l}\text { Improve the business climate to facilitate } \\
\text { private sector-led growth, and enhance } \\
\text { competitiveness }\end{array}$ \\
\hline
\end{tabular}

1 Previously end-September 2011 structural benchmark

2 Previously end-March 2011 structural benchmark 


\section{Attachment 2: Kingdom of Lesotho-Technical Memorandum of Understanding}

1. This memorandum sets forth the understandings between the government of Lesotho and the IMF staff regarding the definitions of the quantitative performance criteria and benchmarks for the second, third and fourth reviews of its arrangement under the ECFsupported program, as well as the respective reporting requirements. These performance criteria and benchmarks are reported in Table 1 of the government's Memorandum of Economic and Financial Policies (MEFP).

\section{A. Ceiling on the Domestic Financing Requirement (DFR) of the Central Government}

2. Definition. The central government includes the central administration and all district administrations. The domestic financing requirement of the central government is defined as net credit to the government from the banking system (that is, the Central Bank of Lesotho and the commercial banks) plus holdings of treasury bills and other government securities by the nonbank sector. For program monitoring purposes, the domestic financing requirement will be calculated as the change from the end of the previous fiscal year (which runs from April 1 to March 31) of net credit to the government by the banking system and of holdings of treasury bills and other government securities by the nonbank sector. In particular, the calculation of the domestic financing requirement shall include changes in (i) balances held in the privatization account or balances of other accounts into which proceeds from the sale of public enterprises are deposited; (ii) the amount of outstanding treasury bills issued by the Central Bank of Lesotho for monetary policy purposes and held in the balance of the blocked government deposit account used by the Central Bank of Lesotho to sterilize reserve money absorbed by monetary policy operations. The calculation of the domestic financing requirement shall exclude changes in balances held in any account into which revenues collected by the customs department are held pending their transfer to the SACU revenues pool. External debt service, amortization, disbursements and external grants will be calculated at current exchange rates.

3. Supporting material. The Central Bank of Lesotho will provide the monetary survey and other monthly monetary statistics, as well as a table showing the details of all government financing operations from the nonbank public, on a monthly basis and within 30 days of the end of the month. The following information will be presented as memorandum items in the monetary survey: (i) the outstanding balances in the privatization account or accounts; and (ii) details of any monetary operations with treasury bills, including changes in government deposits as a result of such operations. The Central Bank of Lesotho will also provide a table showing the details of government debt by type and holder. The Ministry of Finance and Development Planning will provide detailed monthly budget operation reports and tax arrears reports. 


\section{A. Ceiling on the Stock of Net Domestic Assets of the Central Bank of Lesotho}

4. Definition. The net domestic assets (NDA) of the Central Bank of Lesotho are defined as the difference between reserve money (currency in circulation plus total bank deposits at the central bank) and NFA (as defined in paragraph 5). For program monitoring purposes, the NDA will be calculated as the change from the end of the previous fiscal year (which runs from April 1 to March 31). The NDA thus includes net claims by the Central Bank of Lesotho on the government (loans and treasury bills purchased less government deposits), claims on banks, and "other items net" (other assets, other liabilities, and the capital account).

5. Definition. The net foreign assets (NFA) of the Central Bank of Lesotho are defined as foreign assets minus foreign liabilities, and include all foreign claims and liabilities of the central bank. The values of all foreign assets and liabilities will be calculated in U.S. dollars at the end of each quarter using the program exchange rates.

6. Supporting material. The Central Bank of Lesotho will provide detailed data on its balance sheet on a monthly basis within 21 days of the end of the month. The central bank will also provide a table of selected monetary indicators covering the major elements of its balance sheet on a weekly basis.

\section{B. Floor on the Stock of Net International Reserves of the Central Bank of Lesotho}

7. Definition. The net international reserves (NIR) are defined as the Central Bank of Lesotho's liquid, convertible foreign assets minus its short-term foreign liabilities. Pledged or otherwise encumbered assets, including, but not limited to, assets used as collateral or as guarantee for third-party external liabilities are excluded from reserve assets. Reserve assets include cash and balances held with banks, bankers' acceptances, investments, foreign notes and coins held by the Central Bank of Lesotho, Lesotho's reserve position in the Fund, and SDR holdings. Reserve liabilities include nonresident deposits at the Central Bank of Lesotho, use of IMF credit, and any other short term liabilities of the central bank to nonresidents. The stock of NIR at the end of each quarter is defined in U.S. dollars and will be calculated using the program exchange rates. ${ }^{1}$

8. Supporting material. The Central Bank of Lesotho will provide data on its NIR on a monthly basis within three weeks of the end of the month. The NIR data will be provided in a

\footnotetext{
${ }^{1}$ Program cross exchange rates are: South African rand per U.S. dollar: 7.3; U.S. dollars per pound sterling: 1.5; U.S. dollars per euro: 1.3; Swiss francs per U.S. dollar: 1.1; Swedish kronor per U.S. dollar: 7.3; and Botswana pula per U.S. dollar: 6.8. SDR per U.S. dollar: 0.648; Program maloti per U.S. dollar exchange rate: 7.3.
} 
table showing the currency breakdown of the reserve assets and reserve liabilities of the Central Bank of Lesotho converted into U.S. dollars and maloti at the program exchange rates.

\section{Ceiling on the Amount of New Nonconcessional External Debt Contracted or Guaranteed by the Public Sector, with Original Maturity of One Year or More}

9. Definition. For purposes of the ECF arrangement, concessionality requirements will be applied to foreign-currency denominated debt regardless of the residency of the creditor. The public sector comprises the central government, the Central Bank of Lesotho, and all public enterprises and other official sector entities with majority state ownership. This performance criterion applies not only to debt as defined in point No. 9 of the Guidelines on Performance Criteria with Respect to External Debt in Fund Arrangements, adopted by Decision No. 6230-(79/140), as revised on August 24, 2000, as amended effective December 1,2009 , but also to commitments contracted or guaranteed for which value has not been received. Included in this performance criterion are all current liabilities that are created under a contractual arrangement through the provision of value in the form of assets (including currency) or services, and that require the public sector (obligor) to make one or more payments in the form of assets (including currency) at some future point(s) in time to discharge principal and/or interest liabilities incurred under the contract. In effect, all instruments that share the characteristics of debt as described above (including loans, suppliers' credits, and leases) will be subject to the ceiling. New nonconcessional borrowing is limited to the Metolong Dam Project, a high-return public investment project. The performance criterion will be evaluated on a continuous basis as the cumulative change in the amount of new nonconcessional debt contracted or guaranteed from end-March 2010 onward.

10. Definition. A loan is concessional if its grant element is at least 35 percent of the value of the loan, calculated using a discount rate based on commercial interest reference rates (CIRRs) reported by the OECD. For loans of maturity of greater than 15 years, the grant element will be based on the ten-year average of OECD CIRRs. For loans of maturity of 15 years or less, the grant element will be based on the six-month average of OECD CIRRs. Margins for differing repayment periods would be added to the CIRRs: 0.75 percent for repayment periods of less than 15 years, 1 percent for repayment periods of 15 to 19 years, 1.15 percent for repayment periods of 20 to 29 years, and 1.25 percent for repayment periods of 30 years or more.

11. Supporting material. Details of all new commitments and government guarantees for external borrowing, with detailed explanations, will be provided by the Ministry of Finance and Development Planning on a monthly basis within 30 days of the end of the month. 


\section{Ceiling on the Amount of New External Debt Contracted or Guaranteed by the Public Sector, with Original Maturity of Less than One Year}

12. Definition. The public sector comprises the central government, the Central Bank of Lesotho, and all enterprises with majority state ownership. This performance criterion applies not only to debt as defined in point No. 9 of the Guidelines on Performance Criteria with Respect to External Debt in Fund Arrangements, adopted by Decision No. 6230-(79/140), as revised on August 24, 2000, as amended effective December 1, 2009, but also to commitments contracted or guaranteed for which value has not been received. Included in this performance criterion are all current liabilities that are created under a contractual arrangement through the provision of value in the form of assets (including currency) or services, and that require the public sector (obligor) to make one or more payments in the form of assets (including currency) at some future point(s) in time to discharge principal and/or interest liabilities incurred under the contract. In effect, all instruments that share the characteristics of debt as described above (including loans, suppliers' credits, and leases) will be subject to the ceiling. Excluded from this performance criterion are normal short-term import credits. The performance criterion will be evaluated on a continuous basis as the cumulative change in the amount of new nonconcessional debt contracted or guaranteed from the end of the previous fiscal year (March 31).

13. Supporting material. Details of all new commitments and government guarantees for external borrowing, with detailed explanations, will be provided by the Ministry of Finance and Development Planning on a monthly basis within 30 days of the end of the month.

\section{E. Ceiling on the Stock of External Payments Arrears}

14. Definition. During the period of the arrangement, the stock of external payments arrears of the public sector (central government, Central Bank of Lesotho, and all enterprises with majority state ownership) will continually remain zero. Arrears on external debt-service obligations include any nonpayment of interest and/or principal in full and on time falling due to all creditors, including the IMF and the World Bank.

15. Supporting material. Details of arrears accumulated on interest and principal payments to creditors will be reported within one week from the date of the missed payment.

\section{F. Floor on the Central Government Social Expenditures}

16. Definition: There will be a floor on the central government social expenditures from domestic resources. The observance of this floor is an indicative target. Social expenditures comprise spending on the following: school feeding program, old age pension, African Pioneer Corps and HIV/AIDS. 
17. Supporting material: Data on social spending will be compiled by the Ministry of Finance and Development Planning and will be provided on a quarterly basis, to be submitted no later than six weeks after the end of each reporting period.

\section{G. Adjusters}

18. The quantitative performance criteria specified under the program are subject to the following adjusters:

\section{A. Southern African Customs Union Revenues}

- The program targets for the NDA in any quarter will be adjusted downward (upward) by the full amount of any excess (shortfall) in receipts from the Southern Africa Customs Union (SACU) relative to the programmed levels specified in Table 1 of the MEFP as well as any SACU advance receipts in that quarter, where such advance receipts constitute amounts that would otherwise have been received in a subsequent quarter.

- The program targets for the DFR in any quarter will be adjusted downward (upward) by the full amount of any excess (shortfall) in receipts from the Southern Africa Customs Union (SACU) relative to the programmed levels specified in Table 1 of the MEFP as well as any SACU advance receipts in that quarter, where such advance receipts constitute amounts that would otherwise have been received in a subsequent quarter.

- The program targets for the NIR in any quarter will be adjusted upward (downward) by the full amount of any excess (shortfall) in receipts from the Southern Africa Customs Union (SACU) relative to the programmed levels specified in Table 1 of the MEFP as well as any SACU advance receipts in that quarter, where such advance receipts constitute amounts that would otherwise have been received in a subsequent quarter.

19. Supporting material: The Central Bank of Lesotho will provide data on SACU receipts on a quarterly basis within the first month of the quarter.

\section{B. Budgetary Support net of Debt Service ${ }^{2}$}

- The ceiling on the NDA will be adjusted downward (upward) by the full amount of the excess (shortfall) in budgetary support net of external debt service relative to the programmed levels specified in Table 1 of the MEFP.

\footnotetext{
${ }^{2}$ General budget support consists of grants and loans received by the Central Government for financing its overall policy and budget priorities.
} 
- The ceiling on the DFR will be adjusted downward (upward) by the full amount of the excess (shortfall) in budgetary support net of external debt service relative to the programmed levels specified in Table 1 of the MEFP.

- The floor on the NIR of the Central Bank of Lesotho will be adjusted upward (downward) by the full amount of the excess (shortfall) in budgetary support net of external debt service relative to the programmed levels specified in Table 1 of the MEFP.

20. Supporting material: Data on budget support and debt service will be compiled by the Ministry of Finance and Development Planning and will be provided on a quarterly basis, to be submitted no later than six weeks after the end of each reporting period.

\section{Unused Metolong loan balance}

- The ceiling on the NDA will be adjusted downward (upward) by the full amount of the excess (shortfall) in budgetary support net of external debt service relative to the programmed levels specified in Table 1 of the MEFP.

- The ceiling on the DFR will be adjusted downward (upward) by the full amount of the excess (shortfall) in budgetary support net of external debt service relative to the programmed levels specified in Table 1 of the MEFP.

- The floor on the NIR of the Central Bank of Lesotho will be adjusted upward (downward) by the full amount of the excess (shortfall) in budgetary support net of external debt service relative to the programmed levels specified in Table 1 of the MEFP.

21. Supporting material: Data on the Metolong project loan balance under the government's accounts will be compiled by the Central Bank of Lesotho and will be provided on a quarterly basis, to be submitted no later than six weeks after the end of each reporting period.

22. The above supporting data and reports required for program monitoring by IMF staff will be transmitted by the authorities to the IMF Resident Representative to Lesotho. 
This page intentionally left blank 


\section{INTERNATIONAL MONETARY FUND}

KINGDOM OF LESOTHO

Staff Report for the 2012 Article IV Consultation and Second and Third Reviews Under the Three-Year Arrangement Under the Extended Credit Facility and a Request for Augmentation of Access Informational Annex

Prepared by the African Department in Consultation with Other Departments Approved by Anne-Marie Gulde-Wolf and Taline Koranchelian

March 23, 2012

- Relations with the Fund. Describes financial and technical assistance by the IMF, and provides information on the exchange rate system. Lesotho's latest Fund arrangement, a three year ECF was approved in June 2010.

- The JMAP Bank-Fund. Describes the priorities and main activities of the World Bank Group and the IMF, and areas of cooperation in their work with the authorities of Lesotho.

- Statistical Issues. Assesses the quality of statistical data. Economic data are adequate for surveillance purposes, though some deficiencies remain. Lesotho subscribes to the GDDS. 


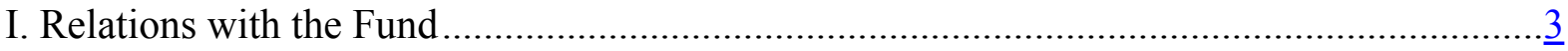

II. The JMAP Bank-Fund Matrix...............................................................................

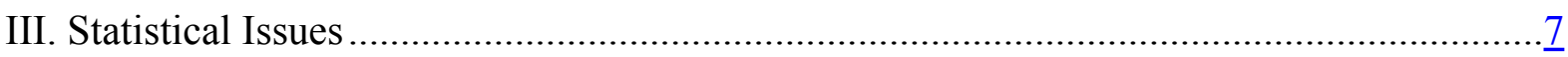




\section{LESOTHO: RELATIONS WITH THE FUND}

(As of February 29, 2012)

I. Membership status: Joined 07/25/1968; accepted the obligations of Article VIII, Sections 2, 3, and 4: 03/05/1997.

II. General resources account:

Quota

Fund holdings of currency

Reserve position in Fund

III. SDR Department:

Net cumulative allocation

Holdings

IV. Outstanding purchases and loans:

$\mathrm{ECF}^{1}$ arrangements $\underline{\text { SDR Million }}$

34.90

31.32

3.61

$\underline{\text { SDR Million }}$

32.88

34.97

$\underline{\text { SDR Million }}$

19.08

$\underline{\text { Percent Quota }}$

54.67

V. Financial arrangements:

$\begin{array}{lcccc}\text { Type } & \begin{array}{c}\text { Approval } \\ \text { Date }\end{array} & \begin{array}{c}\text { Expiration } \\ \text { Date }\end{array} & \begin{array}{c}\text { Amount Approved } \\ \text { (SDR Million) }\end{array} & \begin{array}{c}\text { Amount Drawn } \\ \text { (SDR Million) }\end{array} \\ \text { ECF } & 06 / 02 / 2010 & 06 / 01 / 2013 & 41.88 & 13.48 \\ \text { ECF }^{1} & 03 / 09 / 2001 & 10 / 31 / 2004 & 24.50 & 24.50 \\ \text { Stand-By } & 09 / 23 / 1996 & 9 / 22 / 1997 & 7.17 & 0.0\end{array}$

\footnotetext{
${ }^{1}$ Formerly PRGF.
} 
VI. Projected obligations to fund (SDR million; based on existing use of resources and present holdings of SDRs):

\begin{tabular}{llllll} 
& \multicolumn{5}{c}{ Forthcoming } \\
\cline { 2 - 5 } & $\underline{\underline{2012}}$ & $\underline{\underline{2013}}$ & $\underline{\underline{2014}}$ & $\underline{\underline{2015}}$ & $\underline{2016}$ \\
Principal & 2.80 & 1.75 & 1.05 & 0.78 & 2.13 \\
Charges/Interest & 0.00 & 0.00 & 0.04 & 0.03 & 0.03 \\
Total & $\mathbf{2 . 8 0}$ & $\mathbf{1 . 7 5}$ & $\mathbf{1 . 0 9}$ & $\mathbf{0 . 8 1}$ & $\mathbf{2 . 1 6}$
\end{tabular}

\section{Safeguards Assessment}

An updated safeguards assessment under the 2010 ECF arrangement was completed on December 27, 2010. The CBL has made good progress in implementing the recommendations of the safeguards assessment. Deloitte and Touche (South Africa) was appointed as the CBL's external auditor in 2010. The audit of that year was completed within the statutory deadline and the audited financial statements were published in full on the bank's external website in April 2011. Deloitte \& Touche (South Africa) has been reappointed to conduct the 2011 external audit jointly with a local audit firm. Both firms will sign the audit opinion. It is expected that the audit will be completed by end-March 2012. As recommended by the assessment, the CBL has also introduced internal audits of the monetary data submitted for program monitoring purposes. The authorities are aware that in the event of an augmentation of the existing arrangement, an update assessment will need to be completed.

\section{Exchange arrangement:}

Lesotho is a member of the Common Monetary Area (CMA) and the Lesotho loti is both de facto and de jure pegged at par to the South African Rand, which is also legal tender in the country. Lesotho has accepted the obligations of Article VIII, Sections 2, 3, and 4, of the Articles of Agreement and maintains an exchange system free of restrictions on the making of payments and transfers for current international transactions. As of February 29, 2012, the maloti rate per U.S. dollar was M7.44.

\section{Article IV consultation:}

The 2009 Article IV consultation was concluded by the Executive Board on February 22, 2010. Lesotho is on the standard 24-month Article IV consultation cycle. 


\section{Technical assistance missions:}

Government Finance Statistics: GDDS Project for Anglophone African

$\begin{array}{lll}\text { STA } & \text { short-term } & 2006 \\ & & \\ \text { LEG } & \text { short-term } & 2006 \\ \text { LEG } & \text { short-term } & 2006 \\ \text { MFD } & \text { short-term } & 2006 \\ \text { LEG } & \text { short-term } & 2006 \\ \text { STA } & \text { short-term } & 2007 \\ \text { STA } & \text { short-term } & 2007 \\ \text { MCM } & \text { short-term } & 2007 \\ \text { MCM } & \text { short-term } & 2007 \\ \text { MCM } & \text { short-term } & 2007 \\ \text { MCM } & \text { short-term } & 2007 \\ \text { STA } & \text { short-term } & 2008 \\ & & \\ \text { MCM } & \text { short-term } & 2008 \\ \text { LEG } & \text { short-term } & 2008 \\ \text { STA } & \text { short-term } & 2008 \\ \text { MCM } & \text { short-term } & 2008 \\ \text { MCM } & \text { short-term } & 2008 \\ \text { MCM } & \text { short-term } & 2008 \\ \text { MCM } & \text { short-term } & 2009 \\ \text { STA } & \text { short-term } & 2009 \\ \text { STA } & \text { short-term } & 2010 \\ \text { FAD } & \text { short-term } & 2010 \\ \text { LEG } & \text { short-term } & 2010 \\ \text { MCM } & \text { short-term } & 2010 \\ \text { MCM } & \text { short-term } & 2011 \\ \text { FAD } & \text { short-term } & 2011 \\ \text { MCM } & \text { short-term } & 2011 \\ \text { FAD } & \text { short-term } & 2011 \\ \text { STA } & \text { short-term } & 2011 \\ \text { FAD } & \text { short-term } & 2012 \\ \text { FAD } & \text { short-term } & 2012\end{array}$

Countries

Payment System Reform

Central Banking and Banking Law

Bank Supervision/Monetary Operations/Payments \& Settlements

Legal drafting, AML/CFT, FIU, supervisory and institutional

Regional workshop on the statistical treatment of SACU transfers

Monetary and Financial Statistics

Nonbank supervision

Bank supervision

Monetary operations/Bank supervision

Payment systems

Government Finance Statistics: GDDS Project for Anglophone African

Countries

Money markets

Banking laws and regulation

Balance of payment

Payment systems modernization

Bank supervision

Payment systems

Money markets

Monetary and Financial Statistics

Balance of Payments

Public Financial Management

Financial sector regulations

Payment systems

Monetary and Financial Statistics

Public Financial Management

Financial sector supervision

Revenue administration

SRF data development

Develop risk management function

Develop the post control audit function in custms

FAD

short-term

2012

\section{Missions planned for 2012}

Insurance Supervision

Risk management

Enhanced Insurance Supervision

Risk Management

Balance of payments

Capacity to manage MTEF

Limit accumulation of arrears

MCM short-term 2012

MCM short-term 2012

MCM shor-term 2012

MCM short-term 2012

STA short-term 2012

FAD short-term 2012

FAD short-term 2012

Training functions in customs

FAD short-term 2012

\section{Resident Representatives:}

The IMF will open up a new resident representative office in Maseru soon. The newlyappointed Resident Representative, Mr. Michael Tharkur, is expected to take up his assignment in April 2012. 


\section{LeSOTHO: THE JMAP BANK-FUND MATRIX}

(As of February 29, 2012)

\begin{tabular}{|c|c|c|c|}
\hline Title & Products & $\begin{array}{l}\text { Provisional Timing } \\
\text { of missions }\end{array}$ & $\begin{array}{c}\text { Expected Delivery } \\
\text { date }\end{array}$ \\
\hline \multicolumn{4}{|c|}{ A. Mutual information on relevant work programs } \\
\hline $\begin{array}{l}\text { Bank work } \\
\text { program in } \\
\text { next } 12 \\
\text { months }\end{array}$ & $\begin{array}{l}\text { - Poverty Reduction Support Credit-1 } \\
\text { - Private Sector competitiveness and } \\
\text { Economic Diversification project } \\
\text { - Water Sector Improvement Project Phase } 2 \\
\text { - Public Expenditure Review } \\
\text { - Governance and Public Sector Efficiency } \\
\text { Review } \\
\text { - Smallholder Agriculture Development } \\
\text { Program }\end{array}$ & 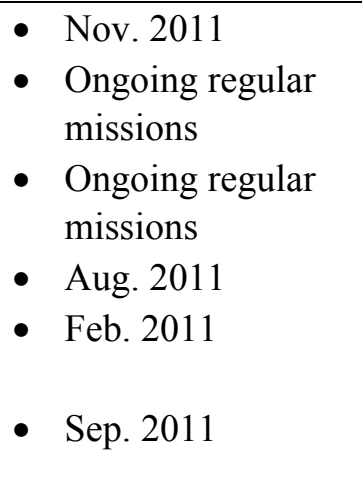 & $\begin{array}{l}\text { - August } 2012 \\
\text { - Implementation } \\
\text { ongoing } \\
\text { - Implementation } \\
\text { ongoing } \\
\text { - April } 20121 \\
\text { - February } 2012 \\
\text { - November } 2011\end{array}$ \\
\hline $\begin{array}{l}\text { IMF work } \\
\text { program in } \\
\text { next } 12 \\
\text { months }\end{array}$ & $\begin{array}{l}\text { Macroeconomic policy analysis and advice } \\
\text { and IMF program } \\
\text { - Fourth review of the ECF } \\
\text { - Fifth review of the ECF } \\
\text { Technical assistance } \\
\text { - Insurance Supervision } \\
\text { - Financial sector risk management } \\
\text { - BOP: Improve data timeliness and quality } \\
\text { - Capacity to manage MTEF } \\
\text { - Limit accumulation of arrears } \\
\text { - Training functions in customs }\end{array}$ & $\begin{array}{l}\text { - Jun. } 2012 \\
\text { - } \text { Nov. } 2012 \\
\text { - } \text { Feb. } 2012 \\
\text { - } \text { Apr. and Jul. } 2012 \\
\text { - Mar. } 2012 \\
\text { - } \text { Mid } 2012 \\
\text { - } \text { Mid } 2012 \\
\text { - } \text { Mid } 2012\end{array}$ & $\begin{array}{l}\text { - September } 2012 \\
\text { - Early } 2013\end{array}$ \\
\hline \multicolumn{4}{|c|}{ B. Requests for work program inputs } \\
\hline $\begin{array}{l}\text { Fund request } \\
\text { to Bank }\end{array}$ & $\begin{array}{l}\text { - Updates on policy reform work: improving } \\
\text { the business climate, economic } \\
\text { diversification, private sector } \\
\text { competitiveness and development, PPP } \\
\text { capacity building, increasing revenue } \\
\text { efficiency } \\
\text { - Updates on budget support programs }\end{array}$ & $\begin{array}{l}\text { - Ongoing } \\
\text { - Ongoing }\end{array}$ & \\
\hline $\begin{array}{l}\text { Bank request } \\
\text { to Fund }\end{array}$ & $\begin{array}{l}\text { - Updates on the ECF program } \\
\text { - Updates on technical support through } \\
\text { IFAD }\end{array}$ & - Ongoing & \\
\hline \multicolumn{4}{|c|}{ C. Agreements on joint products and missions } \\
\hline $\begin{array}{l}\text { Joint } \\
\text { products in } \\
\text { next } 12 \\
\text { months }\end{array}$ & $\begin{array}{l}\text { - Debt sustainability analysis } \\
\text { - JSAN }\end{array}$ & December 2011 & $\begin{array}{l}\text { - March } 2012 \\
\text { - July } 2012\end{array}$ \\
\hline
\end{tabular}




\section{LeSOTHO: STATISTICAL ISSUES}

The statistical database is adequate for surveillance, although there are some deficiencies in core surveillance data, including government finance, monetary and financial statistic and balance of payments statistics that are currently being addressed by the authorities.

As one of 22 countries participating in the GDDS Project for Anglophone African Countries (funded by the U.K. Department for International Development (DFID)), Lesotho has undertaken the GDDS as framework for the development of its national statistical system and a depository of metadata for main macroeconomic aggregates. GDDS metadata have been posted on the Fund's Dissemination Standards Bulletin Board since August 2003. Pending metadata updates in GDDS include those referring to recent/prospective revisions of the national accounts, government finance, and balance of payments statistics.

\section{National accounts}

Revised and rebased national accounts were released in November 2008 by the Lesotho Bureau of Statistics of Lesotho (BOS). Technical assistance from the EU and DFID supported the data revision and the rebasing of the GDP data from 1981 to 2007. Additional revisions and modifications were made in 2009, some due to revisions in the balance of payments. Important new sources of data include the use of VAT records and the 2008 labor force survey. Annual GDP estimates in current prices and volume terms from the production, expenditure, and income sides are currently being produced and published by the BLS, albeit with different time lags. Other macroeconomic indicators, such as high-frequency industrial production/trade indices, are used to monitor developments during the year.

There is a need to further improve the source data used for compiling national accounts. Pending challenges include, inter alia, robust data on intermediate consumption for key economic activities, intra-SACU exports and imports, and gross fixed capital formation in machinery and equipment, and formal and informal construction activities. Private consumption and gross fixed capital formation are now estimated within the framework of a supply and use table. However, it has not been possible to balance supply and use completely, hence the remaining discrepancy between the tables on GDP by activity and expenditure.

\section{Prices}

The consumer price index (CPI) has been revised and the new base period is March 2010. The CPI is estimated on a monthly basis by the BOS and is designated to show changes in the cost of buying a fixed bundle of consumer goods and services as determined for the base period using spending weights from the 2002/03 Household Budget Survey (HBS). Prices are collected every month in twelve urban towns and forty five selected rural areas of Lesotho by personal visits to outlets. 
Plans are in place at the BOS to develop producer and export price indices. In the meantime, the national accounts rely heavily on the South African producer price index (PPI), which is used as a deflator for imports from SACU member countries. South Africa's import price indices are used as deflators for imports from non-SACU countries.

\section{Government finance statistics}

Data on government finance statistics are provided by the Ministry of Finance and Development Planning (MoFDP) to AFR periodically, and the timeliness and quality of the data have improved. Technical assistance from STA and the Development and Implementation of a Macroeconomic Model for Lesotho project (DIMMOL) supported migration of data from GFSM 1986 to the GFSM 2001 framework. AFR has been provided with monthly, quarterly and annual disaggregated central government data (on a cash basis) using the GFSM 2001 framework. These statistics were compiled from the Integrated Financial Management Information System (IFMIS), supplemented with data from the Lesotho Revenue Authority (LRA), other government departments and units and the banking system.

The Integrated Financial Management Information System (IFMIS), introduced in April 2009, and which has modules consistent with the GFSM 2001 framework, is now the main source of government finance statistics. However, as a result of teething problems experienced with the IFMIS, there has been inadequate data capture of revenues and budget execution data, and therefore shortcomings to the data to prepare the budget. Steady progress has been made, with technical assistance from the EU and FAD, to improve the functionality of the IFMIS. To ensure timely reconciliation of and monitoring of budget execution, further improvements are needed, including improving revenue tracking and ensuring proper reconciliation and adequate quality check of data from line ministries and government units. The authorities have integrated the government payroll system (Unique, implemented in September 2009) and the CS-DRMS - the public debt recording and management system -with the IFMIS, and are working to integrate the LRA system - the VIPS. There are also plans to interface IFMIS with the CBL.

The MoFDP also provides annual data to STA on the operations of the general government for publication in the Government Finance Statistics Yearbook. No high frequency data are reported for publication in the International Financial Statistics. The MoFDP disseminates government finance statistics, including government debt, to the public through its website and the website of the Bureau of Statistics.

\section{Monetary and financial statistics}

Lesotho compiles and reports monetary statistics based on the Standardized Report Forms (SRFs). Monthly data using SRFs are disseminated in the IFS. Beginning in January 
2011, data are based on improved sources which allow for better classification and sectorization of accounts closely aligned to the MFSM methodology.

The authorities need to expand the institutional coverage of MFS with respect to both full coverage of other depository corporations and expanding the coverage to include other financial corporations. A monetary and financial statistics mission in May 2011 found that the progress has been very slow in expanding the coverage of monetary statistics mainly because of weaknesses in or nonexistence of reporting frameworks for the financial institutions in question and lack of staff resources to devote to this task.

\section{Balance of payments and external debt}

In 2010, the CBL adopted a new balance of payments database, developed as part of a DIMMOL project to develop an integrated and consistent set of sector flow-of-funds accounts. The development of the external sector account, which began in 2008 , benefited from technical assistance from STA. The new database addresses a number of data and methodological classification issues, including the treatment of SACU transfers. The new database provides an opportunity to improve the format of the quarterly and annual balance of payments statements published by the CBL.

Most of the recommendations made by the 2008 STA mission for improving the quality of balance of payments statistics have been implemented in the new database. A STA mission in April/May 2010 reviewed the balance of payments database and confirmed that it is consistent with the standard presentation recommended by the Balance of Payments Manual, fifth edition (BPM5) and that it meets the need of both the balance of payments and the external accounts. The mission welcomed the work of the DIMMOL, which enables access to other sector accounts, such as fiscal and national accounts, providing data sources that supplement data entered directly into the balance of payments database by the CBL. Following from the 2008 recommendations, private capital flows surveys have become an annual survey and the reports published. The 2008 recommendations for expanding the coverage of International Investment Position (IIP) statistics have not yet been implemented.

The mission emphasized the need for staff training to manage the new database; adoption of the new balance of payments database as the official source; and expansion of IIP coverage to reflect available data sources. On dissemination practices, the mission urged the authorities to publish balance of payments and IIP data consistent with BPM5 in the CBL's Annual Report and Quarterly Review and post the balance of payments and IIP data at the CBL website on a quarterly basis.

Data on public sector external debt is provided by the MoFDP. The MoFDP maintains a comprehensive database of outstanding loans, with information on currency composition, debt service and amortization, as well as scheduled future disbursements and debt servicing. 


\section{Lesotho: Table of Common Indicators Required for Surveillance}

(As of February 29, 2012)

\begin{tabular}{|c|c|c|c|c|c|}
\hline & $\begin{array}{c}\begin{array}{c}\text { Date of } \\
\text { latest } \\
\text { Observation }\end{array} \\
\end{array}$ & $\begin{array}{c}\text { Date } \\
\text { Received }\end{array}$ & $\begin{array}{c}\text { Frequency } \\
\text { of } \\
\text { Data 7/ }\end{array}$ & $\begin{array}{c}\text { Frequency } \\
\text { of } \\
\text { Reporting } 7 /\end{array}$ & $\begin{array}{l}\text { Frequency of } \\
\text { Publication } 7 /\end{array}$ \\
\hline Exchange rates & Feb. 2012 & Feb. 2012 & $\mathrm{D}$ & M & D \\
\hline $\begin{array}{l}\text { International reserve assets and reserve liabilities } \\
\text { of the monetary authorities } 1 /\end{array}$ & Dec. 2011 & Feb. 2012 & M & Q & Q \\
\hline Reserve/base money & Dec. 2011 & Feb. 2012 & M & Q & Q \\
\hline Broad money & Dec. 2011 & Feb. 2012 & M & Q & Q \\
\hline Central bank balance sheet & Dec. 2011 & Feb. 2012 & M & Q & Q \\
\hline Consolidated balance sheet of the banking system & Dec. 2011 & Feb. 2012 & M & Q & Q \\
\hline Interest rates $2 /$ & Dec. 2011 & Feb. 2012 & M & M & M \\
\hline Consumer price index & Dec. 2011 & Feb. 2012 & M & M & M \\
\hline $\begin{array}{l}\text { Revenue, expenditure, balance and composition of } \\
\text { financing } 3 / \text {-general government } 4 /\end{array}$ & $\mathrm{N} / \mathrm{A}$ & $\mathrm{N} / \mathrm{A}$ & $\mathrm{N} / \mathrm{A}$ & $\mathrm{N} / \mathrm{A}$ & $\mathrm{N} / \mathrm{A}$ \\
\hline $\begin{array}{l}\text { Revenue, expenditure, balance and composition of } \\
\text { financing } 3 / \text {-central government }\end{array}$ & Dec. 2011 & Feb. 2012 & M & 1 & Q \\
\hline $\begin{array}{l}\text { Stocks of central government and central } \\
\text { government-guaranteed debt } 5 /\end{array}$ & Dec. 2011 & Feb. 2012 & M & 1 & Q \\
\hline External current account balance & Dec. 2010 & Dec. 2011 & Q & Q & Q \\
\hline Exports and imports of goods and services & Dec. 2010 & Dec. 2011 & Q & Q & Q \\
\hline GDP/GNP & Dec. 2010 & Dec. 2011 & A & A & A \\
\hline Gross external debt & Dec. 2011 & Feb. 2012 & M & Q & Q \\
\hline International investment position $6 /$ & Q2 2011 & Dec. 2011 & Q & Q & Q \\
\hline
\end{tabular}

$1 /$ Includes reserve assets pledged or otherwise encumbered as well as net derivative positions.

2/ Both market-based and officially-determined, including discount rates; money market rates; and rates on treasury bills, notes, and bonds.

3/ Foreign, domestic bank, and domestic nonbank financing.

4/ The general government consist of the central government (budgetary funds, extra budgetary funds, and social security funds) and state and local governments.

$5 /$ Including currency and maturity composition.

6/ Includes external gross financial asset and liability positions vis-à-vis nonresidents.

7/Daily (D), weekly (W), monthly (M), quarterly (Q), annually (A), irregular (I); and N/A. 


\section{INTERNATIONAL MONETARY FUND AND \\ INTERNATIONAL DEVELOPMENT ASSOCIATION}

\section{KINGDOM OF LESOTHO}

\section{Joint World Bank/IMF Debt Sustainability Analysis}

Prepared by the staffs of the International Monetary Fund and the International Development Association

March 23, 2012

Lesotho remains at moderate risk of debt distress. The remittance modified indicators remains below indicative targets under the baseline. Debt ratios are projected to remain manageable over the medium-term as Southern African Customs Union (SACU) revenues recover and the fiscal position improves. ${ }^{1}$ As a small open economy, Lesotho remains vulnerable to adverse global or regional shocks affecting the exchange rate or real GDP growth as well as export growth and nondebt creating flows. The risks appear manageable over the medium-term if the authorities are able to move forward with the planned fiscal adjustment in coming years. The results of this analysis underscore the critical need to realign spending with its sustainable level based on the expected long-run level of SACU revenues, while moving forward with structural reforms to boost productivity and competitiveness in order to accelerate medium-term growth.

\section{INTRODUCTION}

1. This DSA has been prepared jointly by IMF and World Bank staff. It comprises external and domestic debt, and is based on the framework for low-income countries approved by the respective Executive Boards. ${ }^{2}$ The framework takes into account indicative thresholds for debt burden indicators determined by the quality of the country's policies and institutions, ${ }^{3}$ and comprises baseline and alternative scenarios. Given the importance of

\footnotetext{
${ }^{1}$ The analysis has been carried out on fiscal rather than calendar year basis. The fiscal year (FY) starts on April $1^{\text {st }}$. The analysis does not include state owned enterprise debt.

2 See "Applying the Debt Sustainability Framework for Low-Income Countries Post Debt Relief," (IDA/SecM2006-0564 and http://www.imf.org/external/np/pp/eng/2006/110606.pdf and "Staff Guidance Note on the Application of the Joint Fund-Bank Debt Sustainability Framework for Low-Income Countries" http://www.imf.org/external/np/pp/eng/2010/012210.pdf.

${ }^{3}$ The World Bank Country Policy and Institutional Assessment has ranked Lesotho using the three-year moving average as a "medium performer" in terms of policy and institutions with a rating of 3.4. The applicable indicative thresholds for debt sustainability, proposed under the framework for low-income countries are: (i) 40 percent for the NPV of debt-to-GDP ratio, (ii) 150 percent for NPV of debt-to-exports ratio; (iii) 250 percent for the NPV of debt-to-fiscal revenues ratio; (iv) 20 percent for the debt service to exports ratio; and (v) 30 percent for the debt service to revenue ratio.
} 
remittances ${ }^{4}$ in enhancing Lesotho's capacity to repay debt, the DSA also uses the remittance-modified debt indicators to assess the risk of debt distress. ${ }^{5}$

\section{Lesotho's public sector debt declined from 50.6 percent of GDP in 2008/09 to}

35.2 percent at end-2010/11, driven mainly by significant appreciation of the

Loti/Dollar exchange rate for 2009 and 2010. Of the total public sector debt, US\$730 million was owed to external creditors, almost entirely to multilaterals (US\$655 million), mainly IDA and the African Development Fund. Public domestic debt (held by residents) amounted to US\$116 million at the end of 2010/11. At present, domestic debt is composed of Treasury Bills and Treasury Bonds.

Lesotho: Public debt outstanding at end-2010/11

\begin{tabular}{lccc}
\hline & In millions of Maloti & In millions of USD & In percent of GDP \\
\hline Total public debt & 5,744 & 846 & 35.2 \\
Domestic debt & 786 & 116 & 4.8 \\
External debt & 4,958 & 730 & 30.4 \\
Multilateral & 4,446 & 655 & 27.3 \\
IDA & 2,273 & 335 & 13.9 \\
African Development Fund & 1,422 & 209 & 8.7 \\
IMF & 174 & 26 & 1.1 \\
Others & 577 & 85 & 3.5 \\
Export credit & 228 & 34 & 1.4 \\
Bilateral & 216 & 32 & 1.3 \\
Commercial & 68 & 10 & 0.4 \\
\hline
\end{tabular}

Source: Ministry of Finance and Development Planning

3. The large decline in SACU revenues in 2010/11 (equivalent to about 17 percent of GDP) had a significant impact on Lesotho's external and fiscal positions. While the level of SACU transfers is expected to increase as the South African economy recovers, it is unlikely to return to the very high levels (relative to GDP) recorded in recent years. In addition, there is considerable uncertainty regarding the level of SACU revenues over the longer term, with the possibility of revisions to the revenue-sharing formula.

\footnotetext{
${ }^{4}$ The definition of remittances has been revised based on a more detailed BOP framework compared to the one that was used for the previous DSA in May 2010. The revision resulted in lower values both for past years and the projections.

5 See "Applying the Debt Sustainability Framework for low-Income Countries Post Debt Relief," (IDA/SecM2006-0564 and SM/07/131) and "Staff Guidance Note on the Application of the Joint Fund-Bank Debt Sustainability Framework for Low-Income Countries," http://www.imf.org/external/np/pp/eng/2010/012210.pdf. The last DSA prepared in May 2010 also used remittance-modified debt indicators.
} 
4. The impact of the decline in SACU revenues on gross debt has been mitigated by fiscal adjustment and the withdrawal of government deposits at the Central Bank of

Lesotho (CBL). Adjustment policies are being implemented under an ECF arrangement as a means of dealing with the decline in SACU revenues (see staff report of the $2^{\text {nd }}$ review of the ECF arrangement). Having run a fiscal surplus until 2008/09, the government accumulated deposits in the magnitude of 4.5 billion Maloti at the CBL by 2008/09. The government deposits have since been partly withdrawn, reaching 3.4 billion Maloti by September 2011. The government is expected to begin accumulating deposits again by the second quarter of 2012 on the basis of the implementation of the planned fiscal adjustment.

\section{Macroeconomic Assumptions}

5. The baseline scenario below is based on the following macroeconomic projections and assumptions. Compared with the May 2010 DSA, this DSA assumes weaker recovery after the global crisis and higher inflation pressures due to rising international commodity prices. Moreover, the DSA takes into account the strong appreciation of the Loti during the second half of 2010 which lowered the value of foreign denominated debt.

- $\quad$ Output growth reached 3.6 percent in 2009/10, 5.7 percent in 2010/11, and is projected to reach 4.2 percent in 2011/12. Between 2011/12 and 2016/17, growth is expected to average about 4.5 percent of GDP, before increasing to 5 percent between 2017/18 to 2031/32, boosted by the construction of the Metolong dam and the impact of the Lesotho Highlands Water Project, Phase II (LHWP2). The prospect for medium-term growth is favorable, given prospective mining sector investment and assuming that the construction of the Metolong Dam and LHWP2 will allow Lesotho to become an important exporter of water and electricity in the region and put the country in an improved position for attracting FDI.

- Inflation (as measured by the implicit GDP deflator) is assumed to move from an average of 7.4 percent over the last ten years (elevated in part by the food and energy price shocks in 2007-08) to 6.4 percent between 2011/12 and 2016/17, in line with projected consumer price inflation in South Africa. In the longer term, inflation in both Lesotho and South Africa is projected to average 5 percent.

- $\quad$ Fiscal performance in 2010/11 was stronger than envisaged under the original program, reflecting strong revenue performance, boosted by windfall revenues ${ }^{6}$ and a large dividend payment by the CBL as well as containment of expenditure. SACU payments are expected to recover to 29 percent of GDP in 2012/13, before

\footnotetext{
${ }^{6}$ Notwithstanding the large decline in annual SACU payments equivalent to 19.5 percent of GDP in 2011/12, Lesotho received M466.6 million in SACU revenue after tribunal settlement at the Hague of a dispute between South Africa and BLNS over costs incurred in 2006/07-2007/08.
} 
stabilizing around 20 percent of GDP in the medium term. The fiscal deficit reached 5 percent of GDP in 2010/11 and is projected at 10.5 percent of GDP for 2011/12. The deficit is expected to diminish gradually with the government achieving a surplus of 4.3 percent in 2016/17. In the longer term, staff expects zero net domestic borrowing (constant roll-over of existing debt, as the government envisages a fiscal balance in the medium to long-term) and net external borrowing in the magnitude of 1 percent of GDP per year (excluding borrowing for LHWP2 amounting to about 5 percent of GDP between 2017/18 and 2019/20). ${ }^{7}$

- The external current account position deteriorated to an estimated deficit of 14.8 percent of GDP in 2010/11, due to the sharp drop in SACU revenues and a widening of the trade balance deficit. The deficit is expected to increase to 16.6 percent in 2011/12 and then narrow over the medium term, supported by strong export performance in the mining sector and slow import growth as a result of fiscal adjustment. The current account is expected to be about balanced by $2016 / 17$ and to be close to balance in the longer term. Reserve coverage is projected to stabilize at about 6 months of imports of goods and services in the long run.

\section{EXTERNAL DEBT SUSTAINABILITY}

\section{Baseline}

\section{Lesotho's PV of external debt stood at 32.2 percent of GDP at end-2010/11 and is} projected to rise to 39 percent by $2020 / 21$ (Table 1a). This increase is driven predominantly by nonconcessional borrowing for the Metolong dam and LHWP2. The PV of external debt is thus projected to remain below the 40 percent indicative threshold, and to decline thereafter to 25.9 percent in 2031/32. The significant decline in the PV of external debt after 2021/22 is driven partly by the large swing in the grant element of external debt after the amortization of project loans for LHWP2 and Metolong, both of which are assumed to be on commercial terms.

\section{The PV of external debt relative to exports and to revenues would also rise} through 2020/21, but remain well below the respective indicative thresholds of 150 and 250 percent. The ratio of debt service to exports is expected to remain stable around 3-4 percent of GDP between 2010/11 and 2031/32; the ratio of debt service to revenues

\footnotetext{
${ }^{7}$ The construction of both the Metolong Dam and LHWP2 are expected to result in higher tax and export revenues.
} 
increases from 3.6 to 5.7 percent of GDP in 2031/32. Both ratios would remain well below the thresholds due to the highly concessional nature of existing debt. ${ }^{8}$

\section{Alternative scenarios and stress tests}

8. Sensitivity tests show that Lesotho's debt burden would increase in the event of less favorable public sector borrowing terms (Table 1b). In a scenario in which the interest rate on new public sector loans is 2 percentage points higher than the baseline assumption (scenario A2), the PV of debt-to-GDP ratio reaches 43 percent in 2021/22 and falls to 35 percent by 2031/32. The stress tests result in a large and sustained breach of the debt-to-GDP threshold. In a scenario in which the key variables are set at their average of the past 10 years, Lesotho's debt ratios actually fall relative to the baseline, reflecting the average fiscal surplus over this period relative to the significant deterioration in the fiscal position in the projection. However, given the structural break, the historical scenario could be considered less relevant for the analysis.

\section{Bound tests reveal that Lesotho would face most distress in the event of a} nominal exchange rate depreciation or if net nondebt creating flows turned out lower than the historical average. In a scenario with net nondebt creating flows ${ }^{9}$ one standard deviation lower than the historical average, the PV of debt-to-GDP ratio would increase to 56 percent by 2021/22 and then ease to 31 percent in 2031/32. In the event of a one-time 30 percent depreciation of the nominal exchange rate (B6), the PV of debt-to-GDP ratio would similarly increase to 51 percent by $2021 / 22$, but then fall to 35 percent by 2031/32. The indicative threshold of 40 percent would also temporarily be breached in case that the US dollar GDP deflator or export value growth turned out lower than the historical average. The same holds for a combined shock including lower GDP growth and lower nondebt creating flows compared to the historical average.

\section{Public Sector Debt Sustainability}

\section{Baseline}

10. Domestic debt remained relatively low at the end of 2010/11 (4.8 percent of GDP), leaving public debt indicators very closely aligned to those of public external debt (Table 2a). Domestic debt currently comprises Treasury bonds (since 2010/11) and Treasury bills. Domestic debt is projected to fall to 4.2 percent of GDP by 2016/17, and then to gradually fall to 1 percent of GDP in 2031/32. This fall reflects the assumption of zero net domestic borrowing after 2016/17.

\footnotetext{
${ }^{8}$ Borrowing associated with LHWP2 is not assumed to be on concessional terms, resulting in a decline in the overall grant element of borrowing between 2013 and 2019.

${ }^{9}$ Nondebt creating flows include official and private transfers as well as FDI.
} 


\section{Alternative scenarios and stress tests}

11. In the standard sensitivity tests, public sector debt ratios are most sensitive to an unchanged primary balance from 2011/12 (Table $2 \mathrm{~b}$ and Figure 2b). This scenario assumes an unchanged primary balance from 2011/12 onwards, the year in which the country is projected to incur a fiscal deficit of 10.5 percent of GDP and a current account deficit of 16.6 percent of GDP. The scenario results in the PV of debt to GDP rising to 127 percent in 2021/22 and 164 percent in 2031/32. Lower long-run real GDP growth results in the PV of debt to GDP ratio rising to 46 percent in 2021/22 and 47 percent by $2031 / 32$, compared with 27 percent in the baseline scenario in $2031 / 32$. The latter scenario illustrates the vulnerability of the debt trajectory in the event that the ongoing program of infrastructure investment and structural reforms fails to generate sufficient improvement in productivity and competitiveness needed to support the higher real GDP growth rates projected over the medium-term.

\section{CONCLUSION}

12. Lesotho remains at moderate risk of debt distress. The PV of public debt as a ratio to GDP is projected to remain just below the indicative threshold of 40 percent in the baseline scenario. The ratio is projected to decline thereafter as the fiscal remains stable at a small deficit after 2016/17. The ratio also lies below the indicative threshold by the end of the projection period in $2031 / 32$. However, the risk of debt distress is magnified as stress tests result in a protracted breach of indicative thresholds. It increases significantly in the event of adverse shocks to economic growth, significant exchange rate depreciation, or a fiscal balance significantly worse than expected. The risks appear manageable over the medium-term if the authorities are able to move forward with the planned fiscal adjustment in coming years. The results of this analysis underscore the critical need to realign spending with its sustainable level based on the expected long-run level of SACU revenues, while moving forward with structural reforms to boost productivity and competitiveness in order to accelerate medium-term growth.

\section{The authorities broadly agreed with the assessment of moderate risk of debt}

distress. The authorities appreciated that the PV of external debt ratio comes close to breaching the indicative threshold temporarily in 2020/21, partly due to the construction of the Metolong dam and the impact of the LHWP2. They agreed that the risk of debt distress increases significantly in the event of adverse shocks as well as with the need to realign spending with its sustainable level based on the expected long-run level of SACU revenues, while moving forward with structural reforms to boost productivity and competitiveness in order to accelerate medium-term growth. 
Table 1a.: External Debt Sustainability Framework, Baseline Scenario, 2008-2031 1/ (In percent of GDP, unless otherwise indicated)

\begin{tabular}{|c|c|c|c|c|c|c|c|c|c|c|c|c|c|c|c|}
\hline & \multicolumn{3}{|c|}{ Actual } & \multirow{2}{*}{$\begin{array}{l}\text { Historical }{ }^{6 /} \\
\text { Average }\end{array}$} & \multirow{2}{*}{$\begin{array}{l}\text { Standard } \\
\text { Deviation }\end{array}$} & \multicolumn{6}{|c|}{ Projections } & \multirow[b]{2}{*}{$\begin{array}{c}2011-2016 \\
\text { Average }\end{array}$} & \multirow[b]{2}{*}{2021} & \multirow[b]{2}{*}{2031} & \multirow[b]{2}{*}{$\begin{array}{r}2017-203 \\
\text { Average } \\
\end{array}$} \\
\hline & 2008 & 2009 & 2010 & & & 2011 & 2012 & 2013 & 2014 & 2015 & 2016 & & & & \\
\hline External debt (nominal) 1/ & 45.7 & 34.7 & 30.4 & & & 33.7 & 35.9 & 39.1 & 36.5 & 34.9 & 35.0 & & 42.0 & 28.8 & \\
\hline $\mathrm{o} / \mathrm{w}$ public and publicly guaranteed $(\mathrm{PPG})$ & 45.7 & 34.7 & 30.4 & & & 33.7 & 35.9 & 39.1 & 36.5 & 34.9 & 35.0 & & 42.0 & 28.8 & \\
\hline Change in external debt & 45.7 & -11.0 & -4.3 & & & 3.3 & 2.2 & 3.2 & -2.6 & -1.6 & 0.1 & & -1.9 & -1.0 & \\
\hline Identified net debt-creating flows & $\ldots$ & -11.2 & 3.9 & & & 7.2 & -3.0 & -5.1 & -7.6 & -8.9 & -7.6 & & -5.8 & -7.2 & \\
\hline Non-interest current account deficit & -11.5 & 2.7 & 14.5 & -4.3 & 8.5 & 16.4 & 11.0 & 14.8 & 5.2 & -2.2 & -2.0 & & 0.7 & -0.9 & -0.2 \\
\hline Deficit in balance of goods and services & 64.4 & 72.0 & 68.7 & & & 64.3 & 67.7 & 65.7 & 45.3 & 30.5 & 28.0 & & 27.2 & 22.0 & \\
\hline Exports & 54.8 & 42.8 & 43.4 & & & 46.4 & 48.3 & 49.0 & 54.5 & 59.4 & 59.6 & & 65.5 & 68.7 & \\
\hline Imports & 119.2 & 114.7 & 112.1 & & & 110.7 & 116.0 & 114.7 & 99.7 & 90.0 & 87.7 & & 92.7 & 90.6 & \\
\hline Net current transfers (negative $=$ inflow) & -44.8 & -41.9 & -29.6 & -39.1 & 6.0 & -26.7 & -40.5 & -34.9 & -29.9 & -28.5 & -26.9 & & -27.0 & -26.9 & -27.0 \\
\hline o/w official & -37.2 & -34.3 & -22.1 & & & -19.6 & -34.0 & -28.5 & -23.9 & -22.8 & -21.2 & & -21.3 & -21.3 & \\
\hline Other current account flows (negative $=$ net in flow) & -31.1 & -27.3 & -24.6 & & & -21.2 & -16.1 & -15.9 & -10.2 & -4.2 & -3.1 & & 0.6 & 4.0 & \\
\hline Net FDI (negative = inflow) & -6.7 & -5.7 & -5.3 & -5.2 & 0.9 & -8.2 & -12.5 & -19.8 & -11.3 & -5.3 & -5.3 & & -5.3 & -5.3 & -5.3 \\
\hline Endogenous debt dynamics 2 / & $\ldots$ & -8.3 & -5.3 & & & -1.0 & -1.4 & -0.2 & -1.5 & -1.4 & -0.3 & & -1.3 & -0.9 & \\
\hline Contribution from nominal interest rate & $\ldots$ & 0.5 & 0.3 & & & 0.2 & 0.2 & 0.6 & 0.6 & 0.7 & 0.7 & & 0.8 & 0.5 & \\
\hline Contribution from real GDP growth & 0.0 & -1.3 & -1.7 & & & -1.2 & -1.6 & -0.8 & -2.1 & -2.1 & -1.0 & & -2.1 & -1.4 & \\
\hline Contribution from price and exchange rate changes & 0.0 & -7.4 & -3.9 & & & & & & & & & & & & \\
\hline Residual (3-4) 3/ & $\ldots$ & 0.3 & -8.2 & & & -4.0 & 5.2 & 8.4 & 5.0 & 7.3 & 7.7 & & 3.9 & 6.2 & \\
\hline $\mathrm{o} / \mathrm{w}$ exceptional financing & $\ldots$ & 0.0 & 0.0 & & & 0.0 & 0.0 & 0.0 & 0.0 & 0.0 & 0.0 & & 0.0 & 0.0 & \\
\hline PV of external debt 4/ & $\ldots$ & $\ldots$ & 32.2 & & & 34.7 & 36.0 & 35.6 & 32.6 & 29.6 & 29.0 & & 37.3 & 25.9 & \\
\hline In percent of exports & $\ldots$ & $\ldots$ & 74.1 & & & 74.8 & 74.5 & 72.7 & 59.9 & 49.9 & 48.7 & & 57.0 & 37.6 & \\
\hline PV of PPG external debt & $\ldots$ & $\ldots$ & 32.2 & & & 34.7 & 36.0 & 35.6 & 32.6 & 29.6 & 29.0 & & 37.3 & 25.9 & \\
\hline In percent of exports & .... & ... & 74.1 & & & 74.8 & 74.5 & 72.7 & 59.9 & 49.9 & 48.7 & & 57.0 & 37.6 & \\
\hline In percent of government revenues & $\ldots$ & $\ldots$ & 71.3 & & & 80.5 & 63.6 & 66.9 & 66.5 & 61.1 & 60.6 & & 77.9 & 54.0 & \\
\hline Debt service-to-exports ratio (in percent) & 3.8 & 5.3 & 3.8 & & & 2.5 & 2.7 & 3.7 & 3.1 & 2.5 & 2.5 & & 3.4 & 4.0 & \\
\hline PPG debt service-to-exports ratio (in percent) & 3.8 & 5.3 & 3.8 & & & 2.5 & 2.7 & 3.7 & 3.1 & 2.5 & 2.5 & & 3.4 & 4.0 & \\
\hline PPG debt service-to-revenue ratio (in percent) & 3.3 & 3.8 & 3.6 & & & 2.7 & 2.3 & 3.4 & 3.4 & 3.1 & 3.1 & & 4.6 & 5.7 & \\
\hline Total gross financing need (Millions of U.S. dollars) & -247.7 & -14.1 & 245.8 & & & 230.2 & -6.4 & -83.8 & -130.8 & -196.1 & -198.9 & & -112.5 & -334.9 & \\
\hline Non-interest current account deficit that stabilizes debt ratio & -57.2 & 13.7 & 18.8 & & & 13.1 & 8.8 & 11.6 & 7.8 & -0.6 & -2.1 & & 2.6 & 0.0 & \\
\hline \multicolumn{16}{|l|}{ Key macroeconomic assumptions } \\
\hline Real GDP growth (in percent) & 4.7 & 3.6 & 5.7 & 3.8 & 1.2 & 4.2 & 5.2 & 2.2 & 5.9 & 6.3 & 3.1 & 4.5 & 5.0 & 5.0 & 5.0 \\
\hline GDP deflator in US dollar terms (change in percent) & -11.3 & 19.3 & 12.8 & 9.0 & 19.0 & 3.9 & 2.6 & -0.4 & 3.4 & 4.2 & 1.4 & 2.5 & 2.0 & 2.0 & 2.0 \\
\hline Effective interest rate (percent) $5 /$ & - & 1.2 & 1.1 & 1.2 & 0.1 & 0.6 & 0.6 & 1.6 & 1.8 & 2.0 & 2.1 & 1.4 & 1.9 & 1.6 & 1.8 \\
\hline Growth of exports of G\&S (US dollar terms, in percent) & -3.4 & -3.6 & 21.1 & 14.1 & 15.6 & 15.6 & 12.3 & 3.2 & 21.8 & 20.8 & 4.9 & 13.1 & 8.0 & 7.3 & 8.1 \\
\hline Growth of imports of G\&S (US dollar terms, in percent) & -3.0 & 18.9 & 16.5 & 10.5 & 16.1 & 6.8 & 13.0 & 0.7 & -4.8 & -0.1 & 1.8 & 2.9 & 4.0 & 7.2 & 7.4 \\
\hline Girant element of new public sector borrowing (in percent) & -500 & & & 10. & 10.1 & 20.0 & 18.1 & 37.5 & 30.2 & 28.9 & 6.4 & 23.5 & 10.7 & 10.7 & 9.1 \\
\hline Government revenues (excluding grants, in percent of GDP) & 62.8 & 59.8 & 45.1 & & & 43.1 & 56.5 & 53.2 & 49.1 & 48.5 & 47.9 & & 47.9 & 47.9 & 47.9 \\
\hline Aid flows (in Millions of US dollars) 7/ & 32.5 & 56.9 & 166.8 & & & 209.5 & 237.8 & 146.1 & 81.1 & 111.8 & 103.8 & & 146.3 & 290.4 & \\
\hline o/w Grants & 32.5 & 56.9 & 166.8 & & & 209.5 & 237.8 & 146.1 & 81.1 & 111.8 & 103.8 & & 146.3 & 290.4 & \\
\hline $\mathrm{o} / \mathrm{w}$ Concessional loans & 0.0 & 0.0 & 0.0 & & & 0.0 & 0.0 & 0.0 & 0.0 & 0.0 & 0.0 & & 0.0 & 0.0 & \\
\hline Grant-equivalent financing (in percent of GDP) $8 /$ & $\ldots$ & $\ldots$ & $\ldots$ & & & 9.0 & 9.7 & 5.8 & 3.0 & 3.6 & 3.1 & & 3.3 & 3.3 & 3.3 \\
\hline Grant-equivalent financing (in percent of external financing) $8 /$ & $\ldots$ & $\ldots$ & $\ldots$ & & & 83.3 & 74.5 & 90.6 & 83.7 & 89.1 & 71.8 & & 61.6 & 59.5 & 54.9 \\
\hline \multicolumn{16}{|l|}{ Memorandum items: } \\
\hline Nominal GDP (Millions of US dollars) & 1538.4 & 1900.9 & 2267.0 & & & 2453.2 & 2647.8 & 2695.2 & 2950.6 & 3267.6 & 3415.2 & & 4812.5 & 9555.7 & \\
\hline Nominal dollar GDP growth & -7.1 & 23.6 & 19.3 & & & 8.2 & 7.9 & 1.8 & 9.5 & 10.7 & 4.5 & 7.1 & 7.1 & 7.1 & 7.1 \\
\hline PV of PPG external debt (in Millions of US dollars) & & & 772.9 & & & 830.7 & 931.5 & 941.1 & 946.2 & 948.4 & 967.8 & & 1751.8 & 2411.5 & \\
\hline (PVt-PVt-1)/GDPt-1 (in percent) & & & & & & 2.6 & 4.1 & 0.4 & 0.2 & 0.1 & 0.6 & 1.3 & 1.1 & 0.9 & 2.0 \\
\hline Gross workers' remittances (Millions of US dollars) & 245.7 & 299.8 & 365.0 & & & 356.5 & 349.5 & 337.8 & 338.0 & 346.0 & 351.5 & & 304.1 & 111.7 & \\
\hline PV of PPG external debt (in percent of GDP + remittances) & $\ldots$ & $\ldots$ & 27.7 & & & 30.3 & 31.8 & 31.6 & 29.3 & 26.8 & 26.3 & & 35.1 & 25.6 & \\
\hline PV of PPG external debt (in percent of exports + remittances) & $\ldots$ & $\ldots$ & 54.1 & & & 57.0 & 58.5 & 57.9 & 49.5 & 42.3 & 41.5 & & 51.9 & 37.0 & \\
\hline Debt service of PPG external debt (in percent of exports + remitt & $\ldots$ & $\ldots$ & 2.8 & & & 1.9 & 2.1 & 3.0 & 2.5 & 2.1 & 2.1 & & 3.1 & 3.9 & \\
\hline
\end{tabular}

: County a a toities; and stafestimites ad projections

$1 /$ Includes both public and private sector external debt.

Derived as $[\mathrm{r}-\mathrm{g}-\rho(1+\mathrm{g})](1+\mathrm{g}+\rho+\mathrm{g} \rho)$ times previous period debt ratio, with $\mathrm{r}=$ nominal interest rate; $\mathrm{g}=$ real GDP growth rate, and $\rho=$ growth rate of GDP deflator in U.S. dollar terms.

3 / Includes exceptional financing (i.e., changes in arrears and debt relief); changes in gross foreign assets; and valuation adjustments. For projections also includes contribution from price and exchange rate changes.

4/ Assumes that PV of private sector debt is equivalent to its face value.

$6 /$ Historical averages and standard deviations are generally derived over the past 10 years, subject to data availability.

7/ Defined as grants, concessional loans, and debt relief.

8/ Grant-equivalent financing includes grants provided directly to the government and through new borrowing (difference between the face value and the PV of new debt). 
Table 1b.Lesotho: Sensitivity Analysis for Key Indicators of Public and Publicly Guaranteed External Debt, 2011-2031 (In percent)

\begin{tabular}{|c|c|c|c|c|c|c|c|c|}
\hline & \multicolumn{8}{|c|}{ Projections } \\
\hline & 2011 & 2012 & 2013 & 2014 & 2015 & 2016 & 2021 & 2031 \\
\hline \multicolumn{9}{|c|}{ PV of debt-to GDP ratio } \\
\hline Baseline & 35 & 36 & 36 & 33 & 30 & 29 & 37 & 26 \\
\hline \multicolumn{9}{|l|}{ A. Alternative Scenarios } \\
\hline A1. Key variables at their historical averages in 2011-2031 1/ & 35 & 29 & 24 & 20 & 17 & 16 & 9 & 1 \\
\hline A2. New public sector loans on less favorable terms in 2011-2031 2 & 35 & 36 & 36 & 33 & 30 & 30 & 43 & 35 \\
\hline \multicolumn{9}{|l|}{ B. Bound Tests } \\
\hline B1. Real GDP growth at historical average minus one standard deviation in 2012-2013 & 35 & 36 & 36 & 33 & 30 & 29 & 37 & 26 \\
\hline B2. Export value growth at historical average minus one standard deviation in 2012-2013 3/ & 35 & 40 & 47 & 44 & 40 & 39 & 44 & 27 \\
\hline B3. US dollar GDP deflator at historical average minus one standard deviation in 2012-2013 & 35 & 40 & 44 & 41 & 37 & 36 & 46 & 32 \\
\hline B4. Net non-debt creating flows at historical average minus one standard deviation in 2012-2013 4/ & 35 & 51 & 68 & 63 & 58 & 57 & 56 & 31 \\
\hline B5. Combination of B1-B4 using one-half standard deviation shocks & 35 & 54 & 71 & 67 & 61 & 60 & 59 & 32 \\
\hline B6. One-time 30 percent nominal depreciation relative to the baseline in 2012 5/ & 35 & 50 & 49 & 45 & 41 & 40 & 51 & 35 \\
\hline \multicolumn{9}{|c|}{ PV of debt-to-exports ratio } \\
\hline Baseline & 75 & 75 & 73 & 60 & 50 & 49 & 57 & 38 \\
\hline \multicolumn{9}{|l|}{ A. Alternative Scenarios } \\
\hline A1. Key variables at their historical averages in 2011-2031 1/ & 75 & 59 & 48 & 36 & 29 & 26 & 13 & 1 \\
\hline A2. New public sector loans on less favorable terms in 2011-2031 2 & 75 & 74 & 73 & 61 & 51 & 50 & 65 & 50 \\
\hline \multicolumn{9}{|l|}{ B. Bound Tests } \\
\hline B1. Real GDP growth at historical average minus one standard deviation in 2012-2013 & 75 & 73 & 71 & 59 & 49 & 47 & 55 & 37 \\
\hline B2. Export value growth at historical average minus one standard deviation in 2012-2013 3/ & 75 & 95 & 115 & 96 & 80 & 78 & 80 & 47 \\
\hline B3. US dollar GDP deflator at historical average minus one standard deviation in 2012-2013 & 75 & 73 & 71 & 59 & 49 & 47 & 55 & 37 \\
\hline B4. Net non-debt creating flows at historical average minus one standard deviation in 2012-2013 4/ & 75 & 105 & 139 & 116 & 98 & 96 & 86 & 45 \\
\hline B5. Combination of B1-B4 using one-half standard deviation shocks & 75 & 113 & 143 & 120 & 101 & 99 & 89 & 46 \\
\hline B6. One-time 30 percent nominal depreciation relative to the baseline in 20125 / & 75 & 73 & 71 & 59 & 49 & 47 & 55 & 37 \\
\hline \multicolumn{9}{|c|}{ PV of debt-to-revenue ratio } \\
\hline Baseline & 81 & 64 & 67 & 66 & 61 & 61 & 78 & 54 \\
\hline \multicolumn{9}{|l|}{ A. Alternative Scenarios } \\
\hline A1. Key variables at their historical averages in 2011-2031 1/ & 81 & 50 & 44 & 40 & 36 & 33 & 18 & 1 \\
\hline A2. New public sector loans on less favorable terms in 2011-2031 2 & 81 & 63 & 67 & 67 & 62 & 62 & 89 & 72 \\
\hline \multicolumn{9}{|l|}{ B. Bound Tests } \\
\hline B1. Real GDP growth at historical average minus one standard deviation in 2012-2013 & 81 & 64 & 67 & 67 & 61 & 60 & 77 & 54 \\
\hline B2. Export value growth at historical average minus one standard deviation in 2012-2013 3/ & 81 & 71 & 89 & 89 & 82 & 82 & 91 & 57 \\
\hline B3. US dollar GDP deflator at historical average minus one standard deviation in 2012-2013 & 81 & 71 & 83 & 82 & 76 & 75 & 96 & 66 \\
\hline B4. Net non-debt creating flows at historical average minus one standard deviation in 2012-2013 4/ & 81 & 90 & 128 & 129 & 120 & 120 & 118 & 64 \\
\hline B5. Combination of B1-B4 using one-half standard deviation shocks & 81 & 96 & 134 & 135 & 126 & 126 & 123 & 67 \\
\hline B6. One-time 30 percent nominal depreciation relative to the baseline in $20125 /$ & 81 & 88 & 93 & 92 & 84 & 83 & 107 & 74 \\
\hline
\end{tabular}

Baseline

Debt service-to-exports ratio

A. Alternative Scenarios

A1. Key variables at their historical averages in 2011-2031 1/

A2. New public sector loans on less favorable terms in 2011-2031

B. Bound Tests

B1. Real GDP growth at historical average minus one standard deviation in 2012-2013

B2. Export value growth at historical average minus one standard deviation in 2012-2013 3/

B3. US dollar GDP deflator at historical average minus one standard deviation in 2012-2013

34. Net non-debt creating flows at historical average minus one standard deviation in 2012-2013 4/

B5. Combination of B1-B4 using one-half standard deviation shocks

B6. One-time 30 percent nominal depreciation relative to the baseline in $20125 /$

Debt service-to-revenue ratio

Baseline

A. Alternative Scenarios

A1. Key variables at their historical averages in 2011-2031 1

A2. New public sector loans on less favorable terms in 2011-2031 2

B. Bound Tests

B1. Real GDP growth at historical average minus one standard deviation in 2012-2013

B2. Export value growth at historical average minus one standard deviation in 2012-2013 3

B3. US dollar GDP deflator at historical average minus one standard deviation in 2012-2013

B4. Net non-debt creating flows at historical average minus one standard deviation in 2012-2013 4/

B5. Combination of B1-B4 using one-half standard deviation shocks

B6. One-time 30 percent nominal depreciation relative to the baseline in 2012 5/

Memorandum item:

Memorandum item:
Grant element assumed on residual financing (i.e., financing required above baseline) 6

Sources: Country authorities; and staff estimates and projections.

2/ Assumes that the interest rate on new borrowing is by 2 percentage points higher than in the baseline, while grace and maturity periods are the same as in the baseline.

3/ Exports values are assumed to remain permanently at the lower level, but the current account as a share of GDP is assumed to return to its baseline level after the shock (implicitly assuming

an offsetting adjustment in import levels).

4/ Includes official and private transfers and FDI.

$5 /$ Depreciation is defined as percentage decline in dollar/local currency rate, such that it never exceeds 100 percent.

6/ Applies to all stress scenarios except for A2 (less favorable financing) in which the terms on all new financing are as specified in footnote 2 .

\section{CInternational Monetary Fund. Not for Redistribution}


Table 2a.Lesotho: Public Sector Debt Sustainability Framework, Baseline Scenario, 2008-2031

(In percent of GDP, unless otherwise indicated)

\begin{tabular}{|c|c|c|c|c|c|c|c|c|c|c|c|c|c|c|c|}
\hline & \multicolumn{3}{|c|}{ Actual } & \multirow[b]{2}{*}{ Average ${ }^{5 /}$} & \multirow[b]{2}{*}{$\begin{array}{c}\text { Standard } \\
\text { Deviation } \\
\end{array}$} & \multicolumn{5}{|l|}{ Estimate } & \multicolumn{5}{|c|}{ Projections } \\
\hline & 2008 & 2009 & 2010 & & & 2011 & 2012 & 2013 & 2014 & 2015 & 2016 & $\begin{array}{l}2011-16 \\
\text { Average }\end{array}$ & 2021 & 2031 & $\begin{array}{l}2017-31 \\
\text { Average } \\
\end{array}$ \\
\hline $\begin{array}{l}\text { Public sector debt } 1 / \\
\text { o/w foreign-currency denominated }\end{array}$ & $\begin{array}{l}50.6 \\
45.7\end{array}$ & $\begin{array}{l}38.2 \\
34.7\end{array}$ & $\begin{array}{l}35.2 \\
30.4\end{array}$ & & & $\begin{array}{l}39.6 \\
33.7\end{array}$ & $\begin{array}{l}42.2 \\
35.9\end{array}$ & $\begin{array}{l}45.0 \\
39.1\end{array}$ & $\begin{array}{l}41.7 \\
36.5\end{array}$ & $\begin{array}{l}39.4 \\
34.9\end{array}$ & $\begin{array}{l}39.2 \\
35.0\end{array}$ & & $\begin{array}{l}44.6 \\
42.0\end{array}$ & $\begin{array}{l}29.8 \\
28.8\end{array}$ & \\
\hline Change in public sector debt & 50.6 & -12.4 & -3.0 & & & 4.4 & 2.5 & 2.9 & -3.3 & -2.3 & -0.2 & & -2.2 & -1.1 & \\
\hline Identified debt-creating flows & $\ldots$ & -9.6 & -0.7 & & & 9.8 & -3.9 & -2.0 & -6.4 & -8.3 & -5.8 & & -3.1 & -2.0 & \\
\hline Primary deficit & -9.5 & 3.1 & 4.5 & -5.2 & 7.2 & 9.6 & -1.3 & -1.9 & -3.3 & -5.2 & -5.1 & -1.2 & -0.8 & -0.4 & -0.6 \\
\hline Revenue and grants & 64.9 & 62.8 & 52.5 & & & 51.6 & 65.5 & 58.6 & 51.9 & 52.0 & 50.9 & & 50.9 & 50.9 & \\
\hline of which: grants & 2.1 & 3.0 & 7.4 & & & 8.5 & 9.0 & 5.4 & 2.7 & 3.4 & 3.0 & & 3.0 & 3.0 & \\
\hline Automatic debt dynamics & $\ldots$ & -12.8 & -5.1 & & & 0.1 & -2.6 & -0.1 & -3.1 & -3.1 & -0.7 & & -2.2 & -1.5 & \\
\hline Contribution from interest rate/growth differential & $\ldots$ & -1.3 & -2.0 & & & -1.9 & -2.0 & -0.4 & -2.4 & -2.3 & -1.0 & & -2.2 & -1.5 & \\
\hline of which: contribution from average real interest rate & $\ldots$ & 0.5 & 0.0 & & & -0.4 & 0.0 & 0.5 & 0.1 & 0.1 & 0.2 & & 0.0 & -0.1 & \\
\hline of which: contribution from real GDP growth & 0.0 & -1.7 & -2.1 & & & -1.4 & -2.0 & -0.9 & -2.5 & -2.5 & -1.2 & & -2.2 & -1.5 & \\
\hline Contribution from real exchange rate depreciation & $\ldots$ & -11.5 & -3.1 & & & 2.0 & -0.7 & 0.3 & -0.7 & -0.8 & 0.3 & & $\ldots$ & & \\
\hline Other identified debt-creating flows & 0.0 & 0.0 & 0.0 & & & 0.0 & 0.0 & 0.0 & 0.0 & 0.0 & 0.0 & & 0.0 & 0.0 & \\
\hline Privatization receipts (negative) & 0.0 & 0.0 & 0.0 & & & 0.0 & 0.0 & 0.0 & 0.0 & 0.0 & 0.0 & & 0.0 & 0.0 & \\
\hline Recognition of implicit or contingent liabilities & 0.0 & 0.0 & 0.0 & & & 0.0 & 0.0 & 0.0 & 0.0 & 0.0 & 0.0 & & 0.0 & 0.0 & \\
\hline Debt relief (HIPC and other) & 0.0 & 0.0 & 0.0 & & & 0.0 & 0.0 & 0.0 & 0.0 & 0.0 & 0.0 & & 0.0 & 0.0 & \\
\hline Other (specify, e.g. bank recapitalization) & 0.0 & 0.0 & 0.0 & & & 0.0 & 0.0 & 0.0 & 0.0 & 0.0 & 0.0 & & 0.0 & 0.0 & \\
\hline Residual, including asset changes & $\ldots$ & -2.8 & -2.3 & & & -5.3 & 6.5 & 4.8 & 3.1 & 6.0 & 5.6 & & 0.9 & 0.9 & \\
\hline \multicolumn{16}{|l|}{ Other Sustainability Indicators } \\
\hline PV of public sector debt & ... & $\ldots$ & 37.0 & & & 40.7 & 42.2 & 41.5 & 37.8 & 34.2 & 33.2 & & 39.9 & 26.8 & \\
\hline $\mathrm{o} / \mathrm{w}$ foreign-currency denominated & $\ldots$ & $\ldots$ & 32.2 & & & 34.7 & 36.0 & 35.6 & 32.6 & 29.6 & 29.0 & & 37.3 & 25.9 & \\
\hline $\mathrm{o} / \mathrm{w}$ external & $\ldots$ & $\ldots$ & 32.2 & & & 34.7 & 36.0 & 35.6 & 32.6 & 29.6 & 29.0 & & 37.3 & 25.9 & \\
\hline $\mathrm{PV}$ of contingent liabilities (not included in public sector debt) & $\ldots$ & $\ldots$ & $\ldots$ & & & $\ldots$ & $\ldots$ & $\ldots$ & $\ldots$ & $\ldots$ & $\ldots$ & & $\ldots$ & $\ldots$ & \\
\hline Gross financing need $2 /$ & -6.4 & 6.2 & 6.9 & & & 11.9 & 1.5 & 1.1 & -0.7 & -3.1 & -3.2 & & 1.8 & 2.6 & \\
\hline $\mathrm{PV}$ of public sector debt-to-revenue and grants ratio (in percent) & $\ldots$ & $\ldots$ & 70.5 & & & 78.8 & 64.5 & 70.8 & 72.9 & 65.7 & 65.2 & & 78.2 & 52.7 & \\
\hline PV of public sector debt-to-revenue ratio (in percent) & $\ldots$ & $\ldots$ & 82.0 & & & 94.4 & 74.7 & 78.0 & 77.0 & 70.4 & 69.3 & & 83.2 & 56.0 & \\
\hline $\mathrm{o} / \mathrm{w}$ external $3 /$ & $\ldots$ & 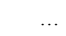 & 71.3 & & & 80.5 & 63.6 & 66.9 & 66.5 & 61.1 & 60.6 & & 77.9 & 54.0 & \\
\hline Debt service-to-revenue and grants ratio (in percent) $4 /$ & 4.7 & 5.0 & 4.7 & & & 4.5 & 4.3 & 5.1 & 5.1 & 3.9 & 3.6 & & 5.2 & 6.0 & \\
\hline Debt service-to-revenue ratio (in percent) $4 /$ & 4.9 & 5.2 & 5.5 & & & 5.4 & 4.9 & 5.6 & 5.4 & 4.2 & 3.9 & & 5.6 & 6.3 & \\
\hline Primary deficit that stabilizes the debt-to-GDP ratio & -60.1 & 15.6 & 7.4 & & & 5.2 & -3.8 & -4.7 & 0.0 & -2.9 & -4.9 & & 1.3 & 0.6 & \\
\hline \multicolumn{16}{|l|}{ Key macroeconomic and fiscal assumptions } \\
\hline Real GDP growth (in percent) & 4.7 & 3.6 & 5.7 & 3.8 & 1.2 & 4.2 & 5.2 & 2.2 & 5.9 & 6.3 & 3.1 & 4.5 & 5.0 & 5.0 & 5.0 \\
\hline Average nominal interest rate on forex debt (in percent) & $\ldots$ & 1.2 & 1.1 & 1.2 & 0.1 & 0.6 & 0.6 & 1.6 & 1.8 & 2.0 & 2.1 & 1.4 & 1.9 & 1.6 & 1.8 \\
\hline Average real interest rate on domestic debt (in percent) & $\ldots$ & 3.6 & 4.5 & 4.1 & 0.7 & 1.0 & 0.0 & 3.5 & 0.5 & 0.1 & 2.8 & 1.3 & 2.7 & 2.7 & 2.7 \\
\hline Real exchange rate depreciation (in percent, + indicates depreciation) & 8.0 & -25.9 & -9.5 & -4.5 & 19.7 & 7.0 & $\ldots$ & $\ldots$ & $\ldots$ & ... & $\ldots$ & $\ldots$ & $\ldots$ & & $\ldots$ \\
\hline Inflation rate (GDP deflator, in percent) & 10.9 & 4.8 & 3.8 & 7.4 & 3.2 & 6.7 & 7.8 & 4.2 & 7.4 & 7.7 & 4.8 & 6.4 & 5.0 & 5.0 & 5.0 \\
\hline Growth of real primary spending (deflated by GDP deflator, in percent) & 0.2 & 0.2 & -0.1 & 0.1 & 0.1 & 0.1 & 0.1 & -0.1 & -0.1 & 0.0 & 0.0 & 0.0 & 0.0 & 0.1 & 0.1 \\
\hline Grant element of new external borrowing (in percent) & $\ldots$ & $\ldots$ & $\ldots$ & $\ldots$ & $\ldots$ & 20.0 & 18.1 & 37.5 & 30.2 & 28.9 & 6.4 & 23.5 & 10.7 & 10.7 & \\
\hline
\end{tabular}

Sources: Country autho

1/ Gross debt is used. The public sector comprises the central government, the Central Bank of Lesotho and all enterprises with majority state ownership.

2/ Gross financing need is defined as the primary deficit plus debt service plus the stock of short-term debt at the end of the last period.

3/ Revenues excluding grants.

finterest and amortization of medium and long-term debt.

$5 /$ Historical averages and standard deviations are generally derived over the past 10 years, subject to data availability. 
Table 2b.Lesotho: Sensitivity Analysis for Key Indicators of Public Debt 2011-2031

\begin{tabular}{|c|c|c|c|c|c|c|c|c|}
\hline & \multicolumn{8}{|c|}{ Projections } \\
\hline & 2011 & 2012 & 2013 & 2014 & 2015 & 2016 & 2021 & 2031 \\
\hline \multicolumn{9}{|c|}{ PV of Debt-to-GDP Ratio } \\
\hline Baseline & 41 & 42 & 41 & 38 & 34 & 33 & 40 & 27 \\
\hline \multicolumn{9}{|l|}{ A. Alternative scenarios } \\
\hline A1. Real GDP growth and primary balance are at historical averages & 41 & 40 & 35 & 31 & 28 & 27 & 18 & -22 \\
\hline A2. Primary balance is unchanged from 2011 & 41 & 52 & 61 & 68 & 75 & 87 & 127 & 164 \\
\hline A3. Permanently lower GDP growth $1 /$ & 41 & 43 & 42 & 39 & 36 & 35 & 46 & 47 \\
\hline \multicolumn{9}{|l|}{ B. Bound tests } \\
\hline B1. Real GDP growth is at historical average minus one standard deviations in 2012-2013 & 41 & 45 & 45 & 42 & 39 & 39 & 49 & 41 \\
\hline B2. Primary balance is at historical average minus one standard deviations in 2012-2013 & 41 & 45 & 48 & 44 & 40 & 39 & 44 & 30 \\
\hline B3. Combination of B1-B2 using one half standard deviation shocks & 41 & 43 & 42 & 39 & 35 & 35 & 43 & 33 \\
\hline B4. One-time 30 percent real depreciation in 2012 & 41 & 57 & 54 & 49 & 44 & 43 & 49 & 37 \\
\hline B5. 10 percent of GDP increase in other debt-creating flows in 2012 & 41 & 51 & 50 & 46 & 42 & 41 & 46 & 31 \\
\hline \multicolumn{9}{|c|}{ PV of Debt-to-Revenue Ratio 2/ } \\
\hline Baseline & 79 & 64 & 71 & 73 & 66 & 65 & 78 & 53 \\
\hline \multicolumn{9}{|l|}{ A. Alternative scenarios } \\
\hline A1. Real GDP growth and primary balance are at historical averages & 79 & 60 & 60 & 60 & 55 & 54 & 36 & -43 \\
\hline A2. Primary balance is unchanged from 2011 & 79 & 79 & 105 & 131 & 145 & 171 & 249 & 321 \\
\hline A3. Permanently lower GDP growth $1 /$ & 79 & 65 & 72 & 75 & 68 & 69 & 91 & 93 \\
\hline \multicolumn{9}{|l|}{ B. Bound tests } \\
\hline B1. Real GDP growth is at historical average minus one standard deviations in 2012-2013 & 79 & 68 & 76 & 81 & 74 & 76 & 96 & 81 \\
\hline B2. Primary balance is at historical average minus one standard deviations in $2012-2013$ & 79 & 69 & 82 & 85 & 77 & 76 & 87 & 59 \\
\hline B3. Combination of B1-B2 using one half standard deviation shocks & 79 & 65 & 72 & 75 & 68 & 68 & 85 & 64 \\
\hline B4. One-time 30 percent real depreciation in 2012 & 79 & 87 & 93 & 95 & 85 & 84 & 96 & 73 \\
\hline B5. 10 percent of GDP increase in other debt-creating flows in 2012 & 79 & 78 & 86 & 89 & 81 & 80 & 91 & 61 \\
\hline \multicolumn{9}{|c|}{ Debt Service-to-Revenue Ratio 2/ } \\
\hline Baseline & 4 & 4 & 5 & 5 & 4 & 4 & 5 & 6 \\
\hline \multicolumn{9}{|l|}{ A. Alternative scenarios } \\
\hline A1. Real GDP growth and primary balance are at historical averages & 4 & 4 & 5 & 4 & 4 & 4 & 4 & 1 \\
\hline A2. Primary balance is unchanged from 2011 & 4 & 3 & 5 & 6 & 6 & 7 & 12 & 22 \\
\hline A3. Permanently lower GDP growth $1 /$ & 4 & 3 & 5 & 5 & 4 & 4 & 6 & 8 \\
\hline \multicolumn{9}{|l|}{ B. Bound tests } \\
\hline B1. Real GDP growth is at historical average minus one standard deviations in 2012-2013 & 4 & 4 & 5 & 5 & 4 & 4 & 6 & 8 \\
\hline B2. Primary balance is at historical average minus one standard deviations in 2012-2013 & 4 & 3 & 5 & 5 & 5 & 4 & 6 & 7 \\
\hline B3. Combination of B1-B2 using one half standard deviation shocks & 4 & 4 & 5 & 5 & 4 & 4 & 5 & 7 \\
\hline B4. One-time 30 percent real depreciation in 2012 & 4 & 4 & 6 & 6 & 6 & 6 & 8 & 10 \\
\hline B5. 10 percent of GDP increase in other debt-creating flows in 2012 & 4 & 3 & 5 & 6 & 5 & 5 & 6 & 7 \\
\hline
\end{tabular}

Sources: Country authorities; and staff estimates and projections.

1/ Assumes that real GDP growth is at baseline minus one standard deviation divided by the square root of the length of the projection period.

2/ Revenues are defined inclusive of grants. 
Figure 1. Lesotho: Indicators of Public and Publicly Guaranteed External Debt under Alternatives Scenarios, 2011-2031 1/
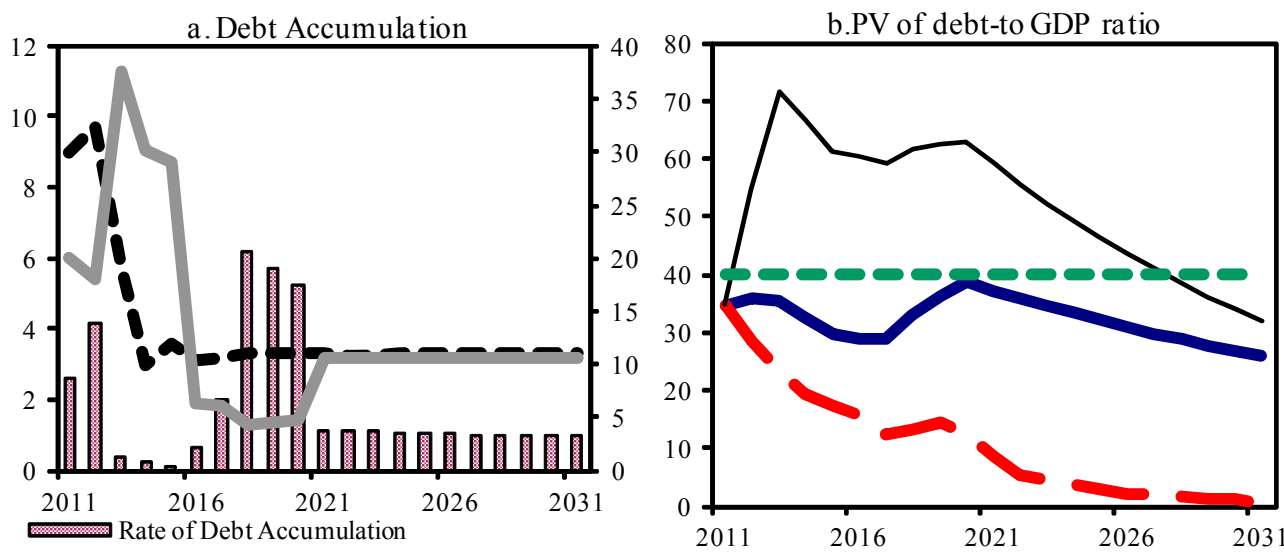

- Grant-equivalent financing (\% of GDP)

Grant element of new borrowing (\% right scale)
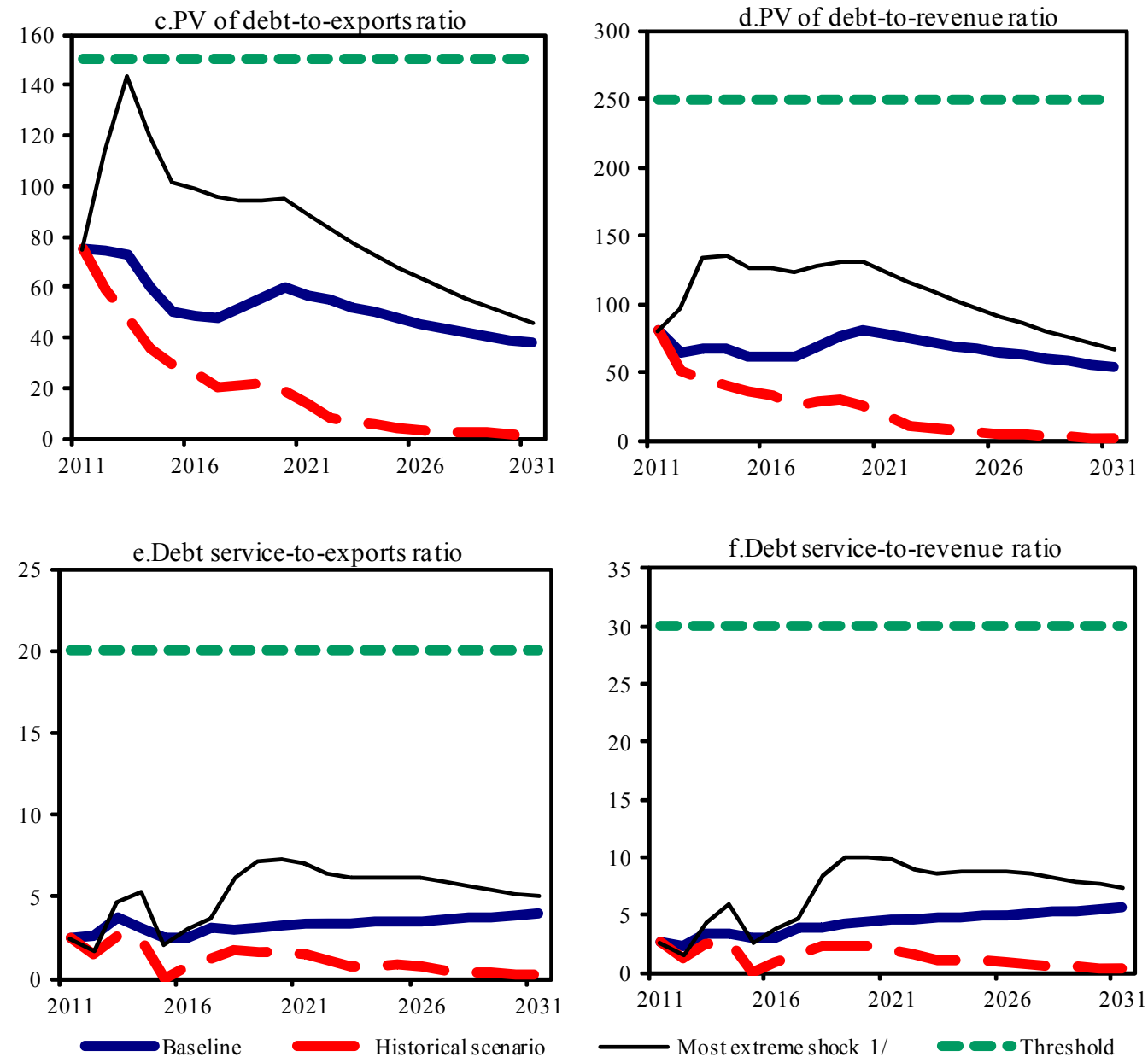

Sources: Country authorities; and staff estimates and projections.

$1 /$ The most extreme stress test is the test that yields the highest ratio in 2021. In figure b. it corresponds to a Combination shock; in c. to a Combination shock; in d. to a Combination shock; in e. to a Combination shock and in figure f. to a Combination shock 
Figure 2a. Lesotho: Indicators of Public and Publicly Guaranteed External Debt under Alternatives Scenarios, 2011-2031 1/
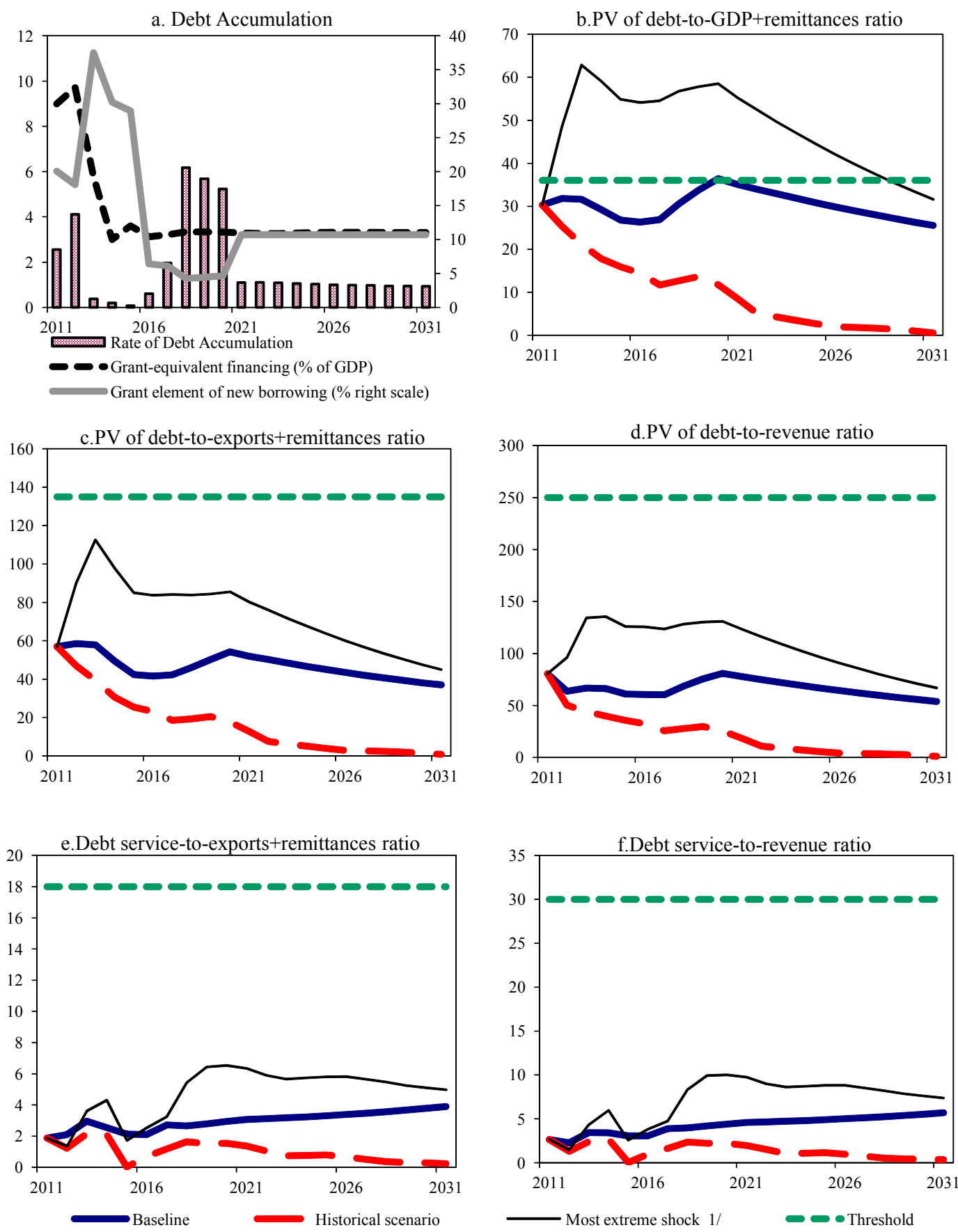

Sources: Country authorities; and staff estimates and projections.

1/ The most extreme stress test is the test that yields the highest ratio in 2021. In figure b. it corresponds to a Combination shock; in c. to a Combination shock; in $\mathrm{d}$. to a Combination shock; in e. to a Combination shock and in figure f. to a Combination shock 
Figure 2b. Lesotho: Indicators of Public and Publicly Guaranteed Debt under Alternatives Scenarios, 2011-2031 1/
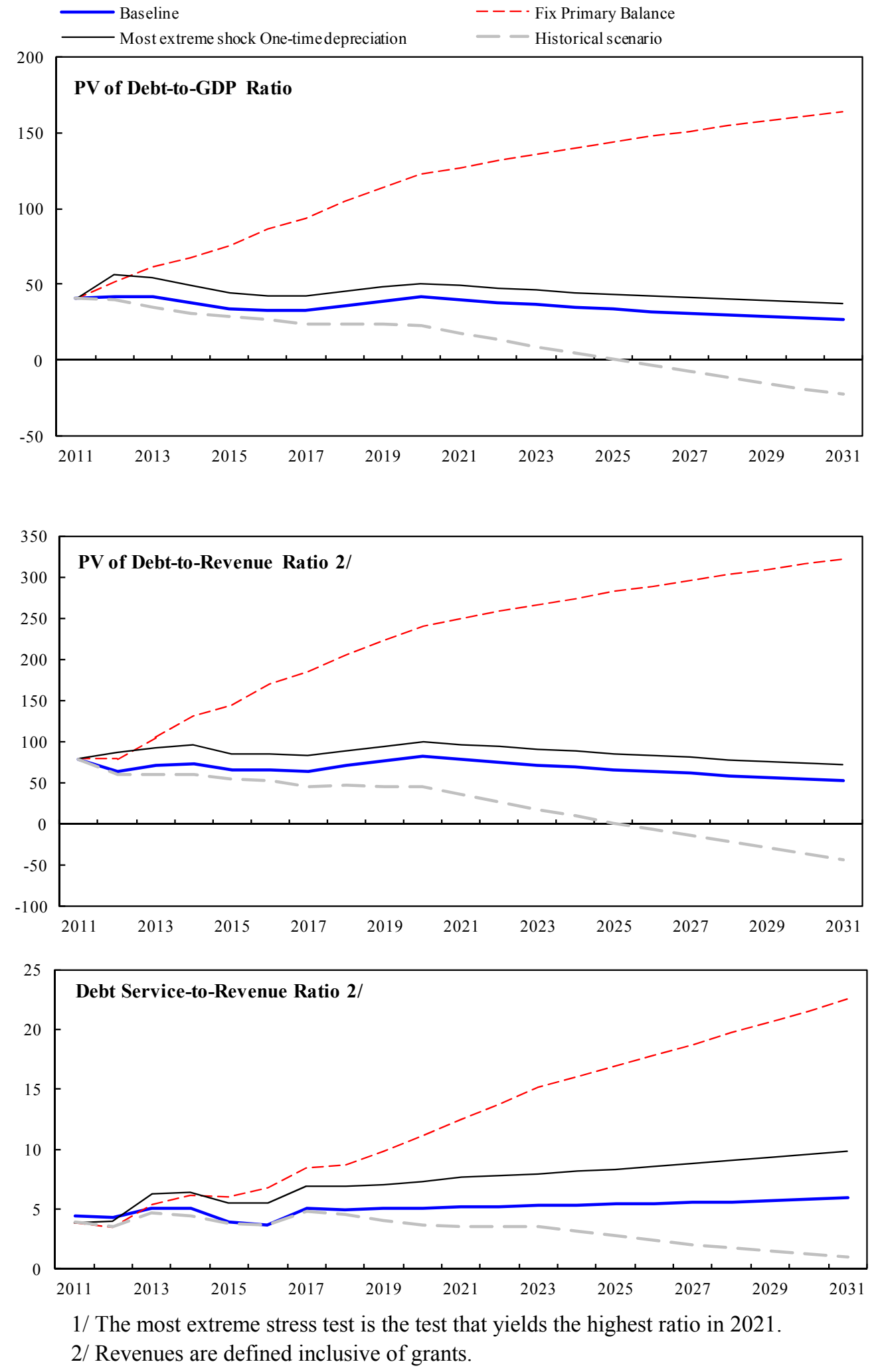
This page intentionally left blank 


\section{INTERNATIONAL MONETARY FUND}

EXTERNAL

\section{Public Information Notice}

RELATIONS

DEPARTMENT

Public Information Notice (PIN) No. 12/41

FOR IMMEDIATE RELEASE

April 27, 2012
International Monetary Fund

$70019^{\text {th }}$ Street, NW

Washington, D. C. 20431 USA

\section{IMF Executive Board Concludes 2012 Article IV Consultation with the Kingdom of Lesotho}

On April 9, 2012, the Executive Board of the International Monetary Fund (IMF) concluded the Article IV consultation with Lesotho. ${ }^{1}$

\section{Background}

Despite the unfavorable external environment (owing to a significant fall in revenues from the Southern African Customs Union (SACU) and floods in early 2011), Lesotho's real gross domestic product (GDP) grew at $53 / 4$ percent in $2010 / 11$ and is projected to increase by $41 / 4$ percent in $2011 / 12$, mainly driven by the mining and construction sectors. Meanwhile, inflation steadily increased in 2011, reaching 7 percent in December, reflecting high international commodity prices and agricultural shortages following months of floods. The external balances remained under pressure from the fall in SACU revenues and the floods, as well as from recent high international commodity prices. The external current account deficit widened to $143 / 4$ percent of GDP in 2010/11, while gross international reserves fell to about four months of imports by end-2011. A new five-year National Strategic Development Plan (covering 2012/13-2016/17) — with a view to achieving sustained growth and poverty reduction—was recently finalized.

In 2010/11-2011/12, significant fiscal consolidation efforts were made to address the drop in SACU revenues. Increased domestic revenue collections and cuts in recurrent spending improved the fiscal position. The core SACU fiscal balance-defined as the fiscal balance excluding the volatile component of SACU revenues and foreign-financed project loansrecorded a deficit of $5 \frac{1}{2}$ percent of GDP in 2010/11 and is projected at 73/4 percent in 2011/12,

\footnotetext{
${ }^{1}$ Under Article IV of the IMF's Articles of Agreement, the IMF holds bilateral discussions with members, usually every year. A staff team visits the country, collects economic and financial information, and discusses with officials the country's economic developments and policies. On return to headquarters, the staff prepares a report, which forms the basis for discussion by the Executive Board. At the conclusion of the discussion, the Managing Director, as Chairman of the Board, summarizes the views of Executive Directors, and this summary is transmitted to the country's authorities. An explanation of any qualifiers used in summing up can be found here: http://www.imf.org/external/np/sec/misc/qualifiers.htm.
} 
significantly below the 20 percent of GDP recorded in 2009/10. The authorities have committed to maintaining the fiscal consolidation efforts in $2012 / 13$. The risk of debt distress remains moderate, despite an increase in public debt in 2011/12 on account of loans for large infrastructure projects.

Although the banking sector has been well regulated and supervised, nonbank financial institutions were generally not comprehensively supervised. The weakness in the regulatory and supervisory framework has been addressed through the adoption of the new Financial Institutions Act, which will guide all aspects of regulation and supervision of both bank and nonbank financial institutions.

Lesotho's medium-term economic outlook is favorable though clouded by significant downside risks, given global economic uncertainties. Lesotho therefore faces the risk of unexpected fall in SACU revenues and in global demand for diamonds. In addition, medium-term growth prospects critically depend on ongoing reforms to improve the business environment and to upgrade the physical infrastructure, to support sustained economic growth and diversification.

\section{Executive Board Assessment}

Executive Directors commended the authorities for the strong implementation of the ECF-supported program, despite devastating floods and a difficult external environment. Directors welcomed the authorities' plans to strengthen Lesotho's fiscal and external positions, achieve broad-based growth for poverty reduction, and strengthen the supervisory and regulatory frameworks for the financial sector.

Directors commended the authorities for their commitment to fiscal prudence, and underscored the importance of continued fiscal consolidation to rebuild international reserves, support the exchange rate peg, and reduce reliance on revenues from the Southern African Customs Union. In this regard, greater revenues from the mining sector could be considered. Directors welcomed the 2012/13 fiscal framework target of an overall surplus, with the underlying measures to restrain recurrent outlays, while safeguarding critical social spending. More broadly, they looked forward to further steps to strengthen public financial management, improve the quality of public expenditure, and boost revenue mobilization. While Lesotho remains at a moderate risk of debt distress, Directors encouraged the authorities to limit non-concessional borrowing to safeguard debt sustainability.

Directors welcomed the progress in strengthening the supervisory and regulatory frameworks for banks and nonbanks, and encouraged further steps in this direction. They also commended the authorities for improvements in the anti-money-laundering framework and the steps underway to increase access to financial services, especially in the rural areas.

Directors stressed the need to accelerate structural reforms to improve the investment climate and competitiveness with a view to supporting private sector-led growth, economic diversification, and poverty reduction. In this regard, they welcomed the finalization of the National Strategic Development Plan. 
Public Information Notices (PINs) form part of the IMF's efforts to promote transparency of the IMF's views and analysis of economic developments and policies. With the consent of the country (or countries) concerned, PINs are issued after Executive Board discussions of Article IV consultations with member countries, of its surveillance of developments at the regional level, of post-program monitoring, and of ex post assessments of member countries with longer-term program engagements. PINs are also issued after Executive Board discussions of general policy matters, unless otherwise decided by the Executive Board in a particular case. 


\section{Lesotho: Selected Economic Indicators, 2009/10-12/13 ${ }^{1}$}

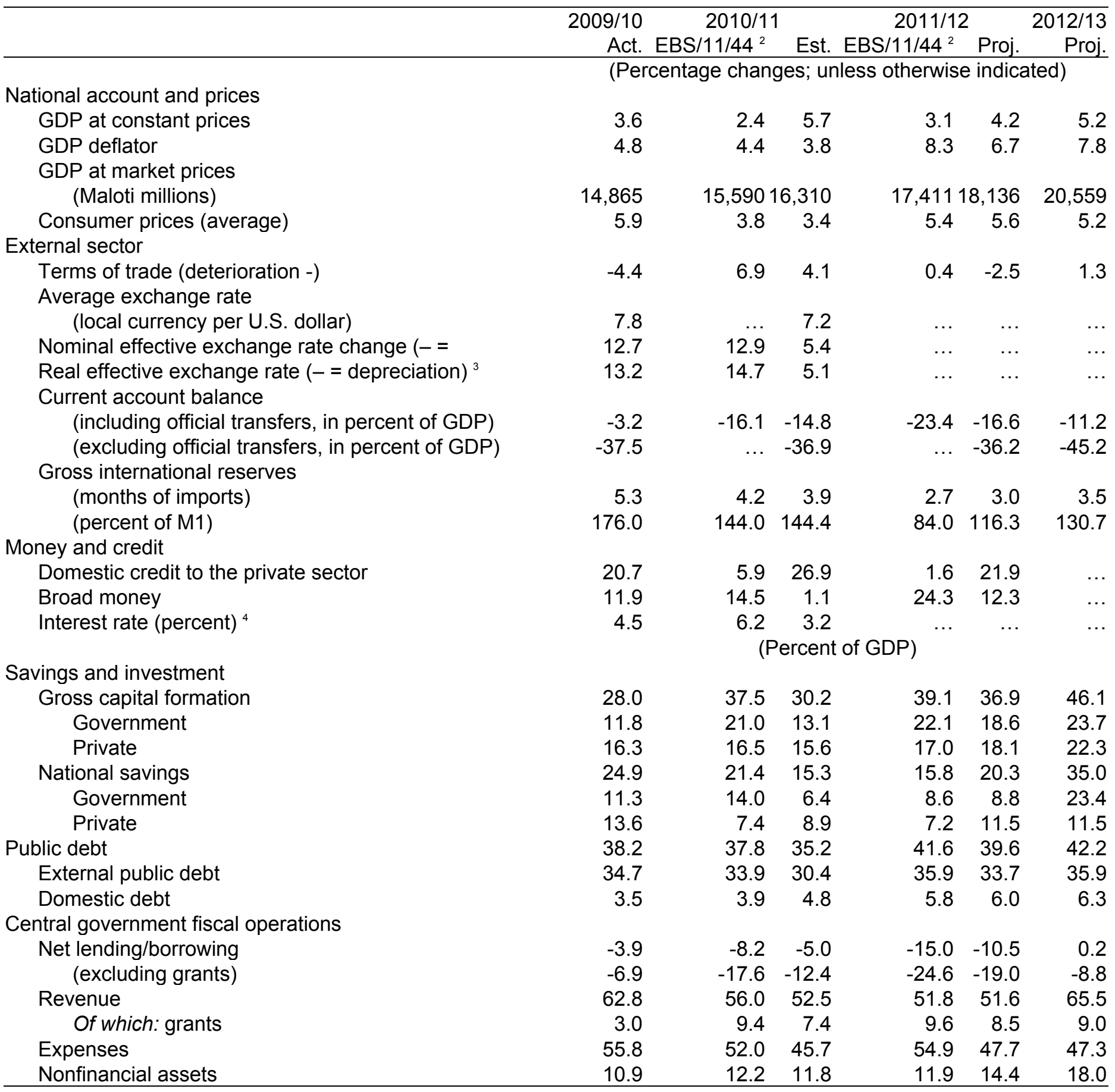

Sources: Lesotho authorities and IMF staff estimates and projections.

${ }^{1}$ The fiscal year runs from April 1 to March 31.

${ }^{2}$ Values as in the first ECF review. Calendar year projections.

${ }^{3}$ IMF Information Notice System trade-weighted; end of period.

${ }^{4}$ 12-month time deposits rate. 
April 9, 2012

\section{IMF Executive Board Completes Second and Third Reviews Under Extended Credit Facility Arrangement for the Kingdom of Lesotho, and Approves Request for Augmentation of Access and US\$13.42 Million Disbursement}

The Executive Board of the International Monetary Fund (IMF) today completed the second and third reviews of the Kingdom of Lesotho's economic performance under a program supported by the Extended Credit Facility (ECF) arrangement. The Board also approved an augmentation of access equal to 25 percent of quota, which would lead to a total access of 145 percent of quota, an amount equivalent to SDR 50.605 million (about US\$77.84 million), under the ECF arrangement. The Board's decision will enable an immediate disbursement of an amount equivalent to SDR 20.085 million (US\$30.89 million), bringing total disbursements under the arrangement to an amount equivalent to SDR 33.565 million (US\$51.63).

The three-year ECF arrangement for the Kingdom of Lesotho in an amount of SDR 41.9 million was approved by the IMF's Executive Board on June 2, 2010 (see Press Release No. 10/224).

Following the Executive Board's discussion on Lesotho, Mr. Min Zhu, Deputy Managing Director and Acting Chair, issued the following statement:

“Lesotho's economy has performed well under the ECF-supported program, notwithstanding a sharp reduction in SACU revenues, devastating floods, and high international commodity prices. Stronger fiscal adjustment efforts and an acceleration of structural reforms are now needed to restore fiscal and external sustainability and pave the way for sustained economic growth and poverty reduction. The augmentation of access under the ECF-supported program, supplemented by donor assistance, will further support the authorities' reform agenda and cushion the impact of the shocks on the balance of payments.

"Given the desirability of maintaining the exchange rate peg, the authorities' medium-term economic program appropriately focuses on fiscal adjustments to rebuild international reserves. The prudent fiscal stance for 2012/13, with emphasis on curbing recurrent

Washington, D.C. 20431 • Telephone 202-623-7100 • Fax 202-623-6772 • www.imf.org 
expenditures while protecting social spending, is an important step in this direction. The efficiency of spending will also be enhanced by improvements in public financial management and the quality of capital spending, while strengthening tax administration will help the achievement of the authorities' medium-term fiscal targets.

"The authorities are committed to accelerating structural reforms to support private sector-led growth and economic diversification. These reforms are aimed at improving the business climate and boosting external competitiveness.

“Lesotho's financial system has remained resilient, and planned regulatory reforms will further strengthen the sector and facilitate financial deepening. Key measures include adopting regulations for the recently enacted Financial Institutions Act, reinforcing the supervisory role of the central bank and broadening access to financial services, especially in the rural areas," Mr. Zhu added. 


\section{Statement by Mr. Majoro on Kingdom of Lesotho April 9, 2012}

\section{Introduction}

My Lesotho authorities highly appreciate the support from staff, management and the Executive Board in their efforts to foster socio-economic development and macroeconomic stability. They value the constructive policy discussions with staff in addressing the challenges to sustainable economic growth, employment creation and poverty reduction. Since the approval of the Extended Credit Facility (ECF) arrangement in June 2010, Lesotho has continued to experience destabilizing exogenous shocks. Following a sharp reduction in government revenue from the Southern African Customs Union (SACU) in 2010/11, the country was hit by floods at the beginning of 2011. In response, the authorities maintained their commitment to fiscal consolidation, but were also confronted with the need to import emergency food and repair damaged infrastructure. As a result, Lesotho's fiscal and external positions remained under considerable pressure. Despite these pressures, Lesotho has maintained prudent macroeconomic policies, supported by the ECF arrangement. My authorities broadly agree with the thrust of the staff report, as it sufficiently presents a balanced assessment of Lesotho's recent macroeconomic developments and outlook, policy achievements, opportunities and inherent challenges.

\section{Program performance}

Despite the exogenous shocks, my Lesotho authorities have maintained strong commitment to the implementation of the policies outlined under the ECF program. All quantitative performance criteria for end-March 2011 and end-September 2011 were met. For the same period, the indicative target for the floor on social spending was met. Moreover, structural reforms remained largely on track, even though delays were experienced in some areas. Specifically, three structural benchmarks for end-March and end-June 2011 have been implemented as programmed. In contrast, two benchmarks were met with delays while three have been postponed, but remain a priority for implementation. Against this background, my authorities are requesting the completion of the second and third reviews; and the augmentation of access to resources amounting to SDR8.73 million.

\section{Recent economic developments}

Notwithstanding the uncertain external environment, Lesotho's macroeconomic conditions remained positive during 2010/11 and 2011/12. Output growth averaged 5.0 per cent, driven mainly by construction, mining and manufacturing subsectors. Construction was significantly influenced by activity related to the construction of the Metolong Dam and the Millennium Challenge Compact. In the meantime, mining output benefited from strong international demand for diamonds and the expansion of mining operations. Furthermore, manufacturing recovered in $2010 / 11$, from the impact of the global financial crisis, as the share of exports to other SACU countries grew noticeably.

Although macroeconomic conditions generally improved, the fiscal and balance of payments positions remained under pressure from sharply reduced SACU revenue during 2010/11 and 
2011/12. Even with these pressures, fiscal operations yielded much smaller deficits than programmed under the ECF as a result of improved collection of domestic revenue and reduced government expenditure. However, strong growth in imports supplemented the steep drop in external revenues to amplify the deterioration in the balance of payments position. As a result, the country's international reserves fell to approximately 4 months of import cover at the end of 2011 from over 5 months in 2009/10.

The rate of consumer price inflation increased to 7.7 percent in December 2011, but moderated to 7.4 percent in February 2012. The increase was driven mainly by rising international commodity prices as well as domestic supply constraints. Moreover, the resurgence in global food and fuel prices is expected to continue to exert inflationary pressures in 2012.

\section{Medium-term outlook and policies}

The medium term outlook remains uncertain due to persistently weak global economic environment. However, the authorities expect generally robust domestic economic performance during 2012/13. GDP is expected to maintain strong growth, boosted by the mining and construction industries. Mining, which is still at its infancy, is set to continue growing, as existing firms expand operations and new ones enter the market. Additional stimulus for the construction industry is expected from Phase II of the Lesotho Highlands Water Project. Meanwhile, a projected recovery in SACU revenue is expected to improve the fiscal and external positions, although still heavily subject to the external environment.

In line with the National Strategic Development Plan 2012/13 - 2016/17 (NSDP), Lesotho's overarching development objective is to accelerate growth, create jobs and reduce poverty. To this end, the authorities will continue to pursue policies aimed at, among others, promoting employment-creating and sustainable economic growth; enhancing democratic governance and effective institutions; and developing key infrastructure to support production. The pursuit of these policies, which are outlined below, will also be supported by the ECF program.

\section{Fiscal policies}

In the medium term, the authorities will pursue fiscal consolidation, limit budget deficits to 3 percent of GDP and maintain public debt at sustainable levels, through various measures. Recurrent expenditure will be kept constant in real terms while priority will be given to spending increases associated with productive investment. In addition, the authorities will enhance their efforts in mobilizing domestic revenue. These measures will also be accompanied by efforts to eliminate wasteful spending and fraud; and improve accountability and efficiency in the management of public finances. Furthermore, proposals for capital projects will be subjected to strict appraisal criteria, to prioritize projects with maximum contribution to economic growth, employment and poverty reduction. Finally, the authorities will work with staff to define the appropriate components of the core SACU fiscal balance, which the authorities are proposing to target with effect from 2012/13. It is expected that these policies will help the authorities to rebuild international reserves to at least five months of imports and continue to maintain the exchange rate parity between the loti and the South Africa rand. 


\section{Monetary and financial sector policies}

My authorities remain committed to the fixed exchange rate arrangement between the loti and the rand, which has over the years anchored price stability in the country. In this regard, Lesotho's monetary policy continues to focus on the maintenance of adequate international reserves to maintain the peg.

On the issue of broader financial sector reforms, the authorities will continue to pursue policy measures aimed at ensuring the soundness and efficiency of the sector. An important milestone was the review of the legislative framework and subsequent enactment, by Parliament in 2011, of the new Financial Institutions Act. Among others, the Act addresses shortcomings in the old legislation such as illegal deposit-taking (including pyramid schemes), and regulation of nonbank financial institutions and large financial cooperatives. It is also intended to strengthen corporate governance in the financial sector. These reforms are intended to reinforce other structural reform measures to promote growth and employment.

\section{Growth, employment and poverty reduction}

The NSDP, which was completed with the support of Lesotho's development partners, identifies key development objectives and strategies to achieve them. In this framework, the authorities have, among others, set the objective of creating an enabling environment for the private sector as an engine of growth and employment creation. They have identified the need for improved productivity and investment climate as important sources of growth. This improvement will be achieved through reforms that will facilitate private sector development and economic diversification, with close cooperation with Lesotho's development partners. Specifically, some of the measures that are intended to improve the business environment include the Partial Credit Guarantee Scheme that was launched in August 2011. This is expected to facilitate greater access to credit by small and medium enterprises. The review of the Companies Act, also under way, is aimed at introducing shorter, simpler and more cost effective mechanisms for incorporation and registration of companies. In the meantime, the Trading Enterprise Regulations have been amended and were published in December 2011, to shorten the time required to start a business and introduce some flexibility with regard to business premises. Furthermore, the authorities intend to submit the Industrial Licensing Bill to Parliament by end-September 2012, which would streamline the process and enhance transparency in granting manufacturing and industrial licenses.

\section{Conclusion}

In conclusion, my authorities continue to demonstrate firm commitment to implement the ECF arrangement as reflected in the strong program performance. Their commitment to the implementation of the policies supported under the program going forward remains unwavering. My Lesotho authorities consider the Fund's and other development partners' policy advice and financial assistance critical to the successful implementation of their development agenda towards achieving inclusive growth and attaining the MDGs. 